\title{
Contemporary Issues in Jus in Bello: Some Problems Raised by Jeff McMahan's Killing in War
}

\author{
By Simon William Bunckenburg
}

A thesis submitted to Victoria University of Wellington in fulfilment of the requirements for the degree of Master of Arts in Philosophy.

Victoria University of Wellington

March 2014 


\title{
Contemporary Issues in Jus in Bello:
}

\section{Some Problems Raised by Jeff McMahan's Killing in War}

\section{Simon William Bunckenburg}

\author{
Victoria University of Wellington
}

The work of Jeff McMahan has revitalised discussion of just war theory with its rejection of the moral equality of combatants. The main aim of this thesis is to explore and develop McMahan's work and recent challenges to it. I do this in four chapters. First, I outline McMahan's account of liability to attack which subsequently shows why the moral equality of combatants is false. I defend his account of liability to attack from problems raised by Yitzhak Benbaji and Thomas Hurka. Second, I discuss developments by McMahan to the in bello condition of proportionality. I suggest that the features McMahan introduces, though innovative, do not go far enough and ultimately argue for David Rodin's multi-factor account. Third, I defend Seth Lazar's responsibility dilemma from objections by McMahan and Bradley Strawser. Fourth, I combine McMahan's understanding of responsibility with Tony Honoré's outcome responsibility and after establishing an account of collective responsibility argue that unjust noncombatants can be liable to intentional attack due to being collectively outcome responsible for the threat their state poses in war. 


\section{Acknowledgements}

I would like to thank all staff and graduate students of the Victoria University of Wellington Philosophy Department, particularly my supervisor, Ramon Das who was extremely generous with his advice and support.

Lauren Brazier has supported me immensely during the course of this project, for which I am extremely grateful.

I received helpful suggestions on this thesis from Felice Marshall, who made sure I justified my claims. I also benefited from the wisdom of Shang-Chin Lai and Molly Woods, who made sure I justified the text. I would also like to thank Clare Davey for her support.

Financial support for this project was gratefully received from Victoria University of Wellington.

Finally, I want to thank my parents Gabrielle Hall and Michael Bunckenburg. 


\section{Contents}

Introduction 6

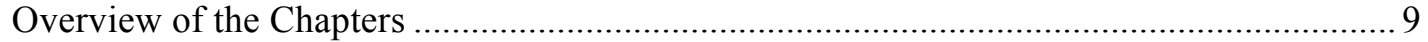

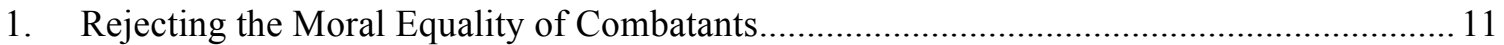

1.1 The Moral Equality of Combatants and the Permissibility of Killing ............................... 12

1.1.1 The traditional understanding of liability to attack ................................................... 14

1.1.2 McMahan's understanding of liability to attack ........................................................ 17

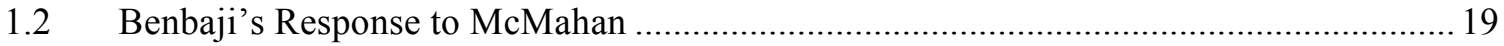

1.2.1 Why the sleeping soldiers are like innocent threats and able to be attacked .............20

1.2.2 Why the sleeping soldiers are permitted to defend themselves .................................2 24

1.2.3 Implications of sleeping soldiers for the independence and symmetry theses ..........26

1.3 Why unjust combatants are unable to satisfy the discrimination requirement ..................22

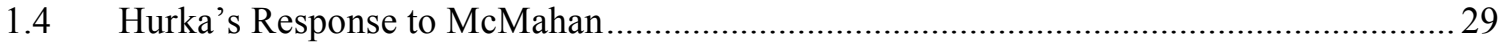

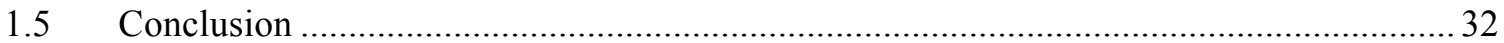

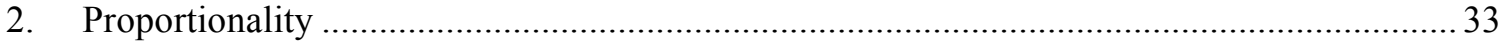

$2.1 \quad$ The Traditional Understanding of Proportionality …….................................................... 33

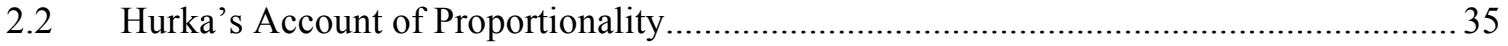

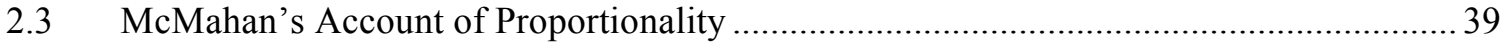

2.3.1 The Goetz case; narrow vs. wide proportionality .................................................... 40

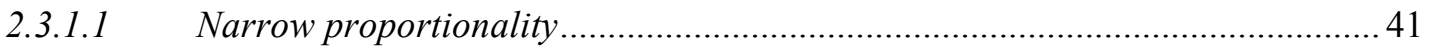

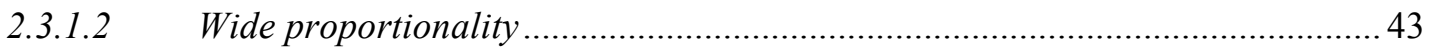

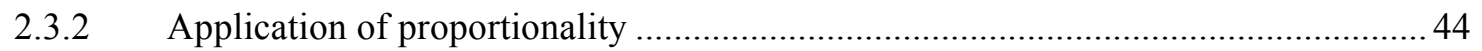

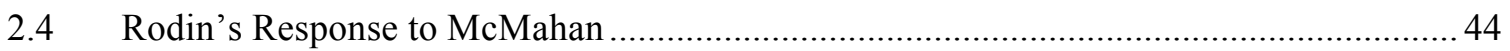

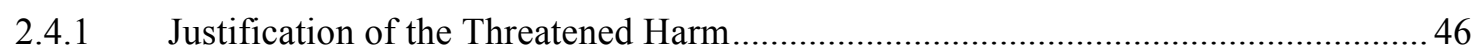

2.4.2 Causal and Temporal Proximity to the Threatened Harm ..........................................4 47

2.4.3 Probability of the Defensive Harm Averting the Threatened Harm ........................... 49

2.4.4 How the Factors Work Together................................................................................... 50

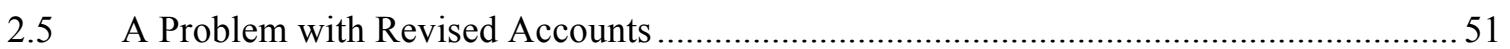

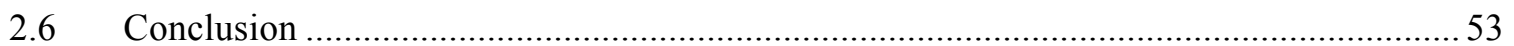

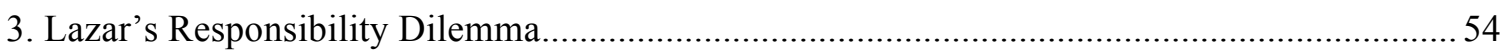

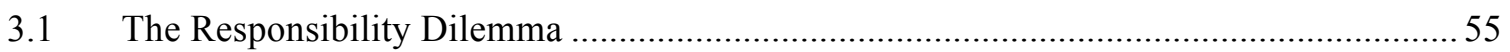

3.1.2 Why epistemic problems support contingent pacifism .............................................57

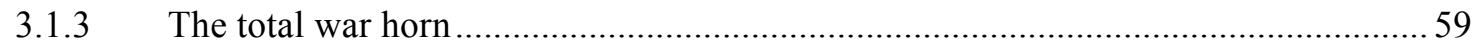




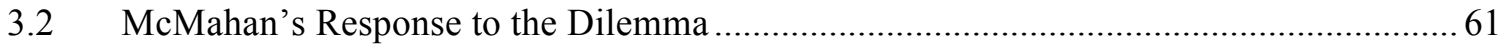

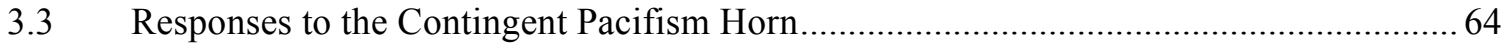

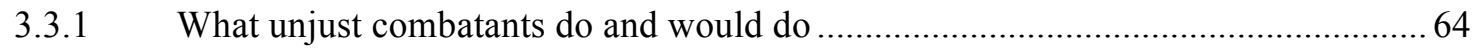

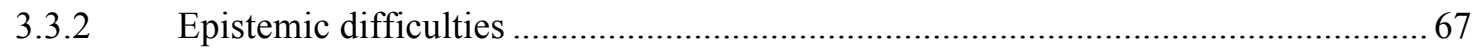

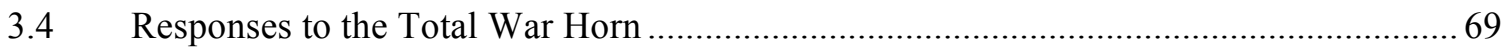

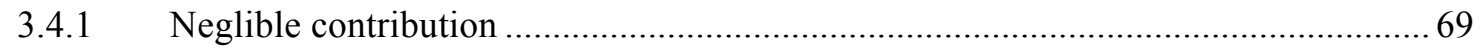

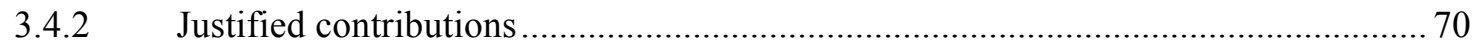

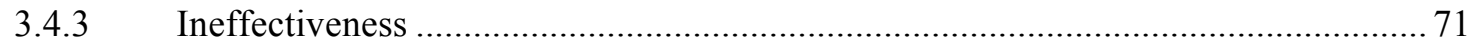

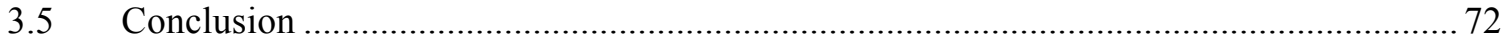

4. Collective Responsibility and Liability to Attack................................................................ 73

4.1 The Collective Nature of the War Time Threat ................................................................... 74

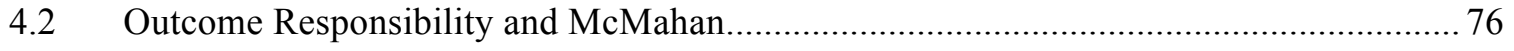

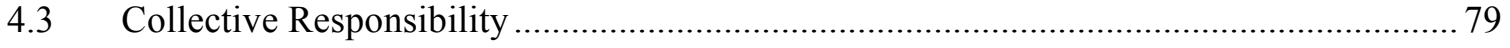

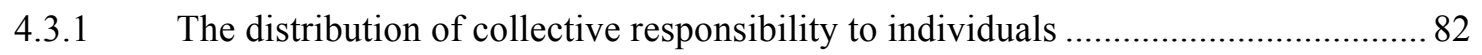

4.4 Objections to Individuals being Outcome Responsible for Collective Action ................... 83

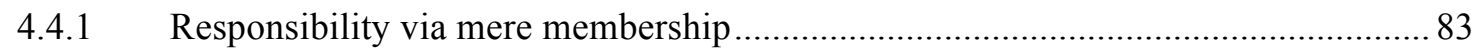

4.4.2 Is it possible to avoid outcome responsibility for collective action? .......................... 85

4.4.2.1 Attributing outcome responsibility to the inactive and the opposed ....................... 85

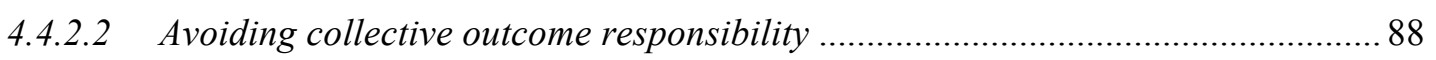

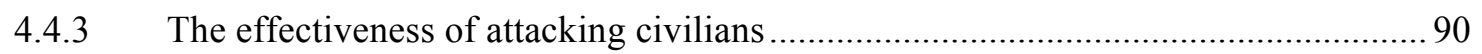

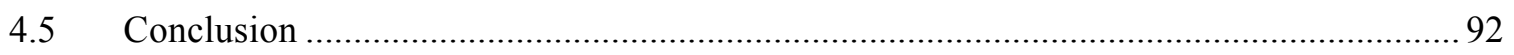

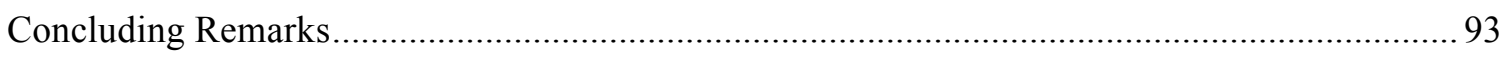

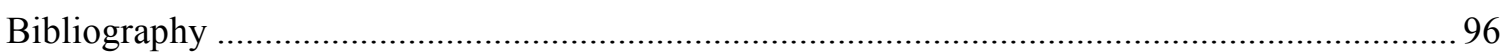




\section{Introduction}

Arguments relating to the moral evaluation of war can be categorised into three main positions: Realism, Pacifism, and Just War Theory. Realists think that moral considerations do not apply to war; pacifists think that wars are (nearly) always unjust; and just war theorists think that wars can sometimes be just. ${ }^{1}$ It is the latter position that is perhaps the most popular among philosophers and is the framework in which I will be working in this thesis.

Just war theorists have traditionally identified two sets of conditions that determine whether a war is just. The first, jus ad bellum, pertains to the justice of going to war, whereas the second, jus in bello, pertains to the justice of participating in a war. Recent work has also focused on a third set of conditions: just post bellum, which pertain to the justice of ending a war. ${ }^{2}$ These conditions will not be discussed in this thesis. The relationship between these sets of conditions is traditionally thought to be subject to the 'independence thesis'. ${ }^{3}$ This states that the in bello principles and ad bellum principles are logically independent, with the ad bellum principles applying to states and their leaders and the in bello principles applying to combatants within a war. More specifically it means that in bello rights and duties are independent of the ad bellum justice of a particular war. This means that a war can meet one set of conditions but not the other. An example of this is the conflict in World War II between Japan and the United States. The participation of the United States in the war was justified under the ad bellum just cause condition, yet in fighting the war they violated the in bello proportionality condition with the dropping of the atomic bombs. ${ }^{4}$ This is because, as Michael Walzer points out: "We

\footnotetext{
${ }^{1}$ For a classic realist account see Hans Morgenthau, Politics Among Nations. For the classic pacifist position see Robert Holmes, On War and Morality.

${ }^{2}$ See, for example, Gary J. Bass 'Jus Post Bellum', Philosophy \& Public Affairs, Vol. 32, No. 4, 2004, pp. 384-412.

3 David Rodin and Henry Shue, 'Introduction', in David Rodin and Henry Shue (eds), Just and Unjust Warriors: The Moral and Legal Status of Soldiers (Oxford: Oxford University Press, 2008), pp. 1-18, at p. 3.

${ }^{4}$ Some historians argue that it was in fact the declaration of war by the Soviet Union that was decisive in the Japanese decision to surrender: Jeff McMahan, Killing in War (Oxford: Oxford University Press, 2009), p. 226.
} 
draw a line between the war itself, for which soldiers are not responsible, and the conduct of the war, for which they are responsible, at least within their own sphere of activity.", So the traditional view of just war theory demarcates between the two sets of principles with jus ad bellum applying to the overall justice of the war and jus in bello applying to the combatants fighting the war.

The independence thesis works with the 'symmetry thesis' to establish the moral equality of combatants. The symmetry thesis states that the rights and obligations of combatants fighting in war are the same. When combined with the independence thesis this establishes the moral equality of combatants by separating the ad bellum and in bello considerations, thereby allowing combatants equal rights. This is a key aspect of the traditional view of just war theory and has the important implication that combatants on both sides of a conflict are morally permitted to kill one another.

The traditional view of just war theory is explained most clearly and comprehensively by Michael Walzer in Just and Unjust Wars. ${ }^{6}$ This book revived interest in the morality of war and has reignited debate in the topic. An important recent challenge to Walzer has come from David Rodin. In War and Self-Defense Rodin directly challenges the ad bellum assumption that the individual right of self-defence translates directly into a national or communal right of self-defence. ${ }^{7}$ This is an ad bellum assumption because self-defence is taken to be the paradigm example of a just cause for war. Rodin's critique poses a significant problem for just war theory, as if wars cannot be justified by selfdefence then it seems to entail that many wars, at least as they are currently fought between states, cannot be justified.

Although I shall be discussing some of Rodin's view below, my focus in this thesis is on the work of Jeff McMahan. In a series of papers and in his book Killing in War McMahan challenges the independence thesis, arguing that ad bellum judgements have implications for the permissibility of war acts. ${ }^{8} \mathrm{He}$ does this by showing that the

\footnotetext{
${ }^{5}$ Michael Walzer, Just and Unjust Wars: A Moral Argument with Historical Illustrations (Fourth Edition), (Basic Books: 2006), p. 38.

${ }^{6}$ Walzer, Just and Unjust Wars.

${ }^{7}$ David Rodin, War and Self-Defense (New York: Oxford University Press, 2002).

${ }^{8}$ See in particular Jeff McMahan, 'Innocence, Self-Defense and Killing in War', The Journal of Political Philosophy, Vol. 2, No. 3, 1994, pp. 193-221; Jeff McMahan, 'Just Cause for War', Ethics \& International
} 
traditional account of liability to attack is false, and develops his own account of liability to attack. This account has significant implications for the moral equality of combatants and the permissibility of killing in war. As such, McMahan's work demands a reexamination of the traditional in bello rights and obligations. In this thesis I focus focusing on the in bello issues that McMahan raises by examining his account and exploring some of the implications of his view. I will not be putting forward a sustained critique of McMahan. Rather, my chapters are relatively self-sufficient, sharing a common theme but focusing on distinct issues that each deserve particular attention.

Before I set out the overview of the thesis it will help to clarify some of the key terms.

A central theme in this thesis is responsibility and as such, it is important to clarify three different types of responsibility. First, there is 'causal responsibility'. This is when an agent is merely causally connected to an event and we would not hold them liable or accountable for the event. An example of this is throwing an orange pip over a cliff and setting off a landslide. Second, there is what Seth Lazar terms 'agent-responsibility' and what Tony Honoré and David Miller call 'outcome responsibility'. 9 This incorporates causal responsibility and adds that the event can be appropriately attributed to the responsible agency of the agent such that it is appropriate for the agent to bear the costs or burdens of their actions. McMahan thinks that agent-responsibility (he simply calls it moral responsibility) is sufficient for liability to attack. Third, there is what Lazar calls 'maximal moral responsibility'. This incorporates the previous two types and also includes the attribution of blame or praise to the agent. So an agent is maximally morally responsible for an event if it is appropriate to blame or praise them for it. If they are blameworthy then we can say that they are culpable for the action. In this thesis particular attention will be paid to the second type of responsibility and I discuss it in more detail in Chapter Four.

Another set of terms that needs clarification is those that describe those who do and do not participate in war. I follow McMahan and use the term 'just combatant' to identify a

Affairs, Vol. 19, No. 3, 2005, pp. 1-21; Jeff McMahan, 'The Ethics of Killing in War', Ethics, Vol. 114, No. 4, 2004, pp. 693-733; and McMahan, Killing in War.

${ }^{9}$ See Seth Lazar, 'The Responsibility Dilemma for Killing in War: A Review Essay', Philosophy \& Public Affairs, Vol. 38, No. 2, 2010, pp. 180-213, at p. 184; Tony Honoré, 'Responsibility and Luck. The Moral Basis of Strict Liability', in Responsibility and Fault (Hart Publishing, 1999), pp. 14-40, at p. 14; and David Miller 'Holding Nations Responsible', Ethics, Vol. 114, No. 2, 2004, pp. 240-268, at p. 245. 
soldier, airman, sailor or any other person who takes up arms whilst fighting a morally justified war. Similarly an 'unjust combatant' refers to those combatants fighting a morally unjustified war. When a state (or nation) is fighting a justified war the members of the population who are not personally taking part in the conflict (i.e. all those who are not combatants) are referred to as 'just noncombatants'. Again, noncombatants whose state is fighting an unjustified war are called 'unjust noncombatants'. The category of noncombatant is essentially the same as the category of civilian; the term 'noncombatant' is used to emphasise the difference with combatants.

\section{Overview of the Chapters}

My thesis is divided into four chapters. In Chapter One I argue against the moral equality of combatants. I start by looking at the traditional account of liability to attack in war and McMahan's criticism of it. The traditional account states that merely posing a threat is sufficient for liable to attack. McMahan argues against it by showing that it has no plausibility outside the context of war. He argues instead for an account of liability to attack that identifies liability as lying in responsibility for an unjust threat of harm. I suggest a modification to McMahan's account of liability to attack in response to a problem raised by Yitzhak Benbaji that brings the problem of innocent threats to the fore. After explaining why McMahan's account renders the moral equality of combatants false I defend McMahan from an objection by Thomas Hurka.

In Chapter Two I look at the recent development of the in bello proportionality requirement. I trace its development from the traditional understanding of Henry Sidgwick and Walzer to a revision by Hurka. I introduce McMahan's account of narrow and wide proportionality which highlight the relevance of liability and intention to proportionality judgements. Following Rodin's lead I criticse McMahan for not including more factors. After discussion of some of those extra factors I ultimately argue in favour of Rodin's approach to proportionality, which involves the considering factors relevant to both the defending and attacking agents.

In Chapter Three I defend Seth Lazar's Responsibility Dilemma. Lazar argues that McMahan is inconsistent in the way he applies his account of liability to attack to unjust combatants and unjust noncombatants. A consistent application will leave McMahan 
facing two horns of a dilemma: either contingent pacifism or total war. I look at responses by McMahan and Bradley Strawser to the dilemma and show why their various criticisms do not defeat the dilemma.

In Chapter Four I argue that McMahan's focus on individual responsibility means that he misunderstands the nature of the war time threat. I argue that war is properly understood as a collective threat. I also argue that McMahan's understanding of moral responsibility is the same as Honoré's outcome responsibility. I develop an account of collective outcome responsibility based on Toni Erskine's work and ultimately argue that many unjust noncombatants are collectively outcome responsible for the threat their state poses in war which means they can be liable to intentional attack. This conclusion is particularly radical and I justify it in part through arguing that it can be effective to kill noncombatants as a means of achieving the just cause.

I turn now to my first chapter and the challenge of showing why the moral equality of combatants is mistaken. 


\section{Rejecting the Moral Equality of Combatants}

In this chapter I am going to set out some of the main arguments surrounding two key contemporary in bello issues: the moral equality of combatants and the moral permissibility of killing in war. The moral equality of combatants is constituted by two theses. ${ }^{10}$ The first is the 'symmetry thesis', which states that the in bello rights and obligations are the same for combatants on both sides of the conflict. In particular they are both morally permitted to kill the opposing combatants, hence the moral equality. The second thesis is the 'independence thesis', which states that the in bello rights and obligations of combatants during war are independent of ad bellum conclusions of the justice of the war. So the moral equality of combatants says that combatants on each side of a conflict are equally permitted to kill each other in war because their in bello rights and obligations are the same. This is in part due to the fact that in bello rights are independent of ad bellum considerations. One of the main reasons for the acceptance of the moral equality of combatants is because of the belief that in war merely posing a threat is sufficient for liability to attack. Combatants on each side threaten the other; hence they are each permitted to kill the other. In Killing in War Jeff McMahan challenges the moral equality of combatants by developing an alternative theory of liability which gives different results for the moral permissibility of killing in war. $\mathrm{He}$ argues that the criterion for liability to attack is moral responsibility for an unjust threat of harm.

My discussion will first outline more detail the arguments around the moral equality of combatants, the traditional understanding of liability to attack, and then McMahan's account of liability to attack. Second, I will set out a response to McMahan based on Yitzhak Benbaji's 'sleeping soldiers' thought experiment. Having overcome the problems raised by sleeping soldiers I will focus on innocent threats and then argue for a

\footnotetext{
${ }^{10}$ Rodin and Shue, 'Introduction', pp. 2-3.
} 
slight modification to McMahan's account in order to accommodate the innocent threats. Third, I will show why McMahan's account demonstrates that unjust combatants are unable to satisfy the in bello requirement of discrimination. This will show why the moral equality of combatants is to be rejected. Fourth, I will look at Thomas Hurka's challenge to McMahan and argue that Hurka's challenge fails in establishing the moral equality of combatants.

\subsection{The Moral Equality of Combatants and the Permissibility of Killing}

The main way a war is prosecuted is through attacking and killing enemy combatants. The most important implication of the symmetry thesis is that it entails that combatants on both sides of the conflict have an equal right to kill the combatants on the opposing side. Provided they do not do so in ways that violate other in bello principles they are morally permitted to kill enemy soldiers.

Two arguments, one principled and one pragmatic, support the moral equality of combatants. The first, which directly supports the independence thesis, is that the responsibility for fighting in a war lies solely with the leader. The nature of political obedience is such that we don't blame a combatant who fights for his own state. ${ }^{11} \mathrm{~A}$ combatant, being a loyal citizen, is in principle not responsible for the policy of the state. That responsibility lies with the sovereign and allows the soldier to accurately channel the English soldier Bates in Henry $V$ who says "Our obedience to the King wipes the crime of it out of us."12 Bates' line is an instance of the independence thesis. The justice of going to war is governed by the ad bellum principles for which the responsibility of satisfying lies with the sovereign. The fact that the responsibility lies with the sovereign is why the moral equality of combatants says that a combatant does not act impermissibly by fighting in a war that doesn't satisfy the ad bellum conditions.

The second argument is grounded in a pragmatic desire to maintain war as a "rulegoverned activity." $" 13$ Walzer identifies war as both a legal and a moral condition which

\footnotetext{
${ }^{11}$ Walzer, Just and Unjust Wars, p. 39.

12 William Shakespeare, Henry V, Andrew Gurr (ed.), (New York: Cambridge University Press, 1992, Updated Edition 2005), IV.i.121-2, at p. 162.

${ }^{13}$ Walzer, Just and Unjust Wars, p. 21.
} 
permits soldiers and armies representing at least two distinct groups to engage in a conflict with armed force. ${ }^{14}$ Part of this condition involves war being a rule-governed activity, with the rules, as codified in international law and drawn from the jus in bello, applying equally to all involved in the conflict. If, Walzer warns us, the equal right to kill were abolished, then "war as a rule-governed activity would disappear and be replaced by crime and punishment, by evil conspiracies and military law enforcement." 15 Though not explicitly stated, the implication seems to be that regulated conflict, i.e. war as it is currently generally practised, is better than unregulated conflict. This entails that the right of soldiers to kill enemy soldiers is a fundamental requirement of regulated conflict. This highlights a tension between just war theorists regarding the motivations for the theory. The tension arises between developing the principles of just war theory to limit an inevitable evil and between simply determining morally appropriate conduct. The former is declared explicitly by Allen Buchanan who states: "The chief practical aim of Just War Theory is to constrain war making." 16 Anthony Coates also supports this, stating that the independence thesis has little logical support and is primarily justified consequentially by its restraint of war. ${ }^{17}$ These views contrast with what James Turner Johnson tells us the original just war question, as framed by medieval Christian Theologians, was: "Is it ever justifiable for Christians to participate in War?"18 Contemporary proponents of the latter position draw inspiration from the self-defence literature where the motivation is not to limit harm, but is rather to simply identify when harm is and is not permissible. Walzer's remarks indicate that he is advancing the moral equality of combatants with the former motivation, of limiting the harm, in mind. The problem with this more pragmatic approach is that the claims it entails are often vulnerable to principled attacks. Jeff McMahan uses such a strategy against the moral equality of combatants.

In Killing in War Jeff McMahan sets out to explicitly reject the independence thesis. He argues that whether or not a combatant is fighting a just or unjust war is relevant to

\footnotetext{
${ }^{14}$ Walzer, Just and Unjust Wars, p. 41.

${ }^{15}$ Walzer, Just and Unjust Wars, p. 41.

${ }^{16}$ Allen Buchanan, 'Institutionalizing the Just War', Philosophy \& Public Affairs, Vol. 34, No. 1, 2006, pp. 2-38, at p. 3 .

${ }^{17}$ Coates argues that revising jus ad bellum is the key to the moral restraint of war in: Anthony Coates, 'Is the Independent Application of jus in bello the Way to Limit War?', in David Rodin and Henry Shue (eds), Just and Unjust Warriors: The Moral and Legal Status of Soldiers (Oxford: Oxford University Press, 2008) pp. 176-192, at p. 177.

${ }_{18}$ James Turner Johnson, Just War Tradition and the Restraint of War: A Moral and Historical Inquiry (Princeton: Princeton University Press, 1981), p. xxv.
} 
whether their killing is morally permissible. In particular his focus on the moral permissibility of killing looks at what is required for someone to be liable to attack. Directly attacking the independence thesis allows McMahan to undermine the symmetry thesis and thereby the moral equality of combatants. This is because if ad bellum considerations affect in bello judgements then it is likely that just and unjust combatants will have different in bello rights and obligations. For McMahan it is generally the case that it is morally wrong to fight in war that lacks a just cause. ${ }^{19}$ This is because he sees the just cause requirement as one of the necessary conditions for the jus ad bellum justice of war. He understands a just cause as an aim that satisfies two conditions: "(1) that it may permissibly be pursued by means of war, and (2) that the reason why this is so is at least in part that those against whom the war is fought have made themselves morally liable to military attack." ${ }^{20}$ It is the second condition that needs to be explained, and McMahan spends time developing the idea of being liable to attack. The reason that McMahan focuses on liability to attack is because it allows him to answer the question of when it is permissible to kill people in war. McMahan is right to focus on this condition as what allows people to be killed in war also serves as an important part of the justification for going to war. If it is not permissible to kill people in war then it will be impermissible to go to war; there will be no just cause. Part of what it means to have a just cause for war is that it is permissible to pursue that cause in a way (subject to in bello conditions) that involves killing.

\subsubsection{The traditional understanding of liability to attack}

McMahan develops the concept of liability to attack in relation to the concept of innocence. He thinks that a person is innocent if that person "has done nothing to make himself morally liable to military attack, ${ }^{21}$ which entails that a person who is morally liable to be attacked is not wronged by being attacked. Walzer understands 'innocent' in terms of rights, where being innocent means having done nothing that entails the loss of rights (to not be attacked, and so on) and McMahan links liability to the loss of this right. ${ }^{22}$ Losing a right is different from cases where rights not to be attacked are waived or overridden. McMahan gives the example of a boxing match to illustrate how boxers

\footnotetext{
${ }^{19}$ As we shall see in Section 1.3 it could be permissible to fight in a war with the intention of preventing atrocities by the just side.

${ }^{20}$ McMahan, Killing in War, p. 5. Emphasis in original.

${ }^{21}$ McMahan, Killing in War, p. 8. Emphasis in original.

${ }^{22}$ Walzer, Just and Unjust Wars, p. 41; McMahan, Killing in War, p. 9.
} 
waive their rights when they consent to be hit as part of the competition. ${ }^{23}$ It is not correct to describe boxers as being liable to attack when they fight, as they have not lost their right not to be attacked. Because they have consented to being attacked it is not a violation of their rights. Similarly, McMahan tells us, a person's right not to be attacked can also be overridden when there are other morally significant considerations that are relevant. ${ }^{24}$ In instances like this we should say that a person's rights had been infringed, rather than violated, as it was permissible (because of the other moral considerations) to act against that person's right. Attacking a person who is liable to be attacked neither violates nor infringes that person's right as being liable to attack means that she has forfeited her right. It is important to note that when a person forfeits her right to life in the context of war she only does so under specific circumstances.

A person is only liable to be harmed if harming her is part of the pursuit of a particular morally acceptable goal. McMahan identifies two typical aims for which people may be liable to attack in warfare: "to prevent the achievement of an unjust cause and to defend people from harms that would otherwise be inflicted by unjust combatants in their efforts to achieve an unjust cause." 25 This stipulation means that a requirement of necessity applies when determining liability. If a proposed harm to a person is not necessary in order to achieve a particular goal then that person is not liable to that harm. Likewise, if the harm would be excessive or disproportionate in relation to the achievement of the aim then the person would not be liable to that harm. McMahan sees both of these considerations as internal to the notion of liability. A person cannot be morally liable to receive a harm that is unnecessary or disproportionate. To state this in a positive sense: a person can only be morally liable to receive a harm that is both necessary and proportionate.

The concept of liability to attack has been used to support the moral equality of combatants. This is because traditional just war theory (as explicated by Anscombe, Nagel, and Walzer) understands the criterion of liability to attack in war simply as posing

\footnotetext{
${ }^{23}$ McMahan, Killing in War, p. 9.

${ }^{24}$ I shall look at an account where these considerations are in play below in Section 1.2.1 when discussing why sleeping soldiers are like innocent threats.

${ }^{25}$ McMahan, Killing in War, p. 8.
} 
a threat. ${ }^{26}$ As all combatants pose a threat, they are all morally liable to attack. ${ }^{27}$ This is based on an etymological understanding of 'innocent', favoured by just war theorists, meaning currently harmless, non-threatening, or non-injurious. Nagel tells us that: "in the definition of murder 'innocent' means 'currently harmless,' and is opposed not to 'guilty' but to "doing harm'." 28 Similarly, Anscombe asserts that innocent means "not harming" and the innocent are those "who are not fighting and not engaged in supplying those who are with the means of fighting." 29 The etymological understanding also explains how a person can lose their right not to be attacked - simply by threatening another and therefore doing them harm. This understanding of innocent is slightly different from the general understanding of the word - being not guilty or not culpable. Indeed, Anscombe explicitly states that 'innocent' in the context of war "is not a term referring to personal responsibility at all." 30 The understanding favoured by just war theorists is also the basis for the in bello principle of discrimination - combatants must restrict their attacks to legitimate targets. Legitimate targets are those who are liable to attack, which under the traditional view are the non-innocent combatants on the opposing side - those who pose a threat. This line of reasoning has led many just war theorists to substitute the discrimination requirement for a principle of noncombatant immunity as they think the legitimate/illegitimate target distinction is the same as the combatant/noncombatant distinction. ${ }^{31}$ McMahan's problem with the mainstream understanding of liability to attack as simply posing a threat is that it does not "have any intuitive plausibility at all outside the context of war." ${ }^{32}$ For the moment I am going to accept this claim because it is prima facie implausible that our moral intuitions about the permissibility of violence are that different in cases of war when compared to cases of relative peace. It may be the case that there are other conditions that affect the permissibility of violence in wartime; I will look at these below. Before that I will look at McMahan's exposition of his claim.

${ }^{26}$ G.E.M. Anscombe, 'War and Murder' in Ethics, Religion and Politics, (Oxford: Oxford University Press, 1981), pp. 51-61; G.E.M. Anscombe, 'Mr Truman's Degree' in Ethics, Religion and Politics, (Oxford: Oxford University Press, 1981), pp. 62-71; G.E.M. Anscombe, 'The Justice of the Present War Examined' in in Ethics, Religion and Politics, (Oxford: Oxford University Press, 1981), pp. 72-81; Thomas Nagel, 'War and Massacre' in Mortal Questions (Cambridge University Press, 1979), pp. 53-74.

${ }^{27}$ McMahan, Killing in War, p. 11.

${ }^{28}$ Nagel, 'War and Massacre', p. 70.

${ }^{29}$ Anscombe, 'Mr Truman's Degree', p.67.

${ }^{30}$ Anscombe, 'Mr Truman's Degree', p.67.

${ }^{31}$ Hurka, Thomas, 'Proportionality in the Morality of War', Philosophy \& Public Affairs, Vol. 33, No. 1, 2005, pp. 34-66, at p. 36. The Stanford Encyclopedia of Philosophy Entry on War also identifies discrimination and noncombatant immunity as being the same principle: Brian Orend, 'War', The Stanford Encyclopedia of Philosophy(Fall 2008 Edition), Edward N. Zalta (ed.), URL: http://plato.stanford.edu/archives/fall2008/entries/war/ (Accessed March 1, 2014).

${ }_{32}$ McMahan, Killing in War, p. 14. 


\subsubsection{McMahan's understanding of liability to attack}

McMahan asks us to consider the case of a murderer who is killing innocent people and a police officer who takes aim to shoot at the murderer. ${ }^{33}$ It does not seem right to say that in doing this the police officer makes himself liable to be harmed by the murderer. This is because the murderer's actions have made himself liable to the defensive action from the police officer. For McMahan a person can have no right of self-defence against a threatened harm to which they have made themselves liable. Hobbes would dispute this, arguing that people have a natural right to defend themselves against imminent threats. ${ }^{34}$ This is a right that is present in the state of nature and one of the few rights Hobbes thinks we cannot give up to the sovereign. ${ }^{35}$ So for Hobbes, even though the police officer is an agent of the sovereign with the authority to keep the peace, the murderer retains a natural right to defend himself against the officer prosecuting that authority. ${ }^{36}$ Few people agree with Hobbes on that point however; a Lockean conception of rights is the dominant view. Hobbesian rights are typically thought to be liberty or simple freedom rights which have no correlation with duties to others, ${ }^{37}$ whereas Lockean rights are often thought to exist in order to allow us to fulfil our duties to others. ${ }^{38}$ Because it seems that we have duties not to harm others, it is implausible that we retain a right to defend ourselves when we are unjustly harming others. Violation of the duty not to harm others is one way to lose the right to self-defence.

McMahan uses the example of the murderer as an analogy to show that in cases of war, defending the innocent and opposing unjust combatants does not make people liable to attack in the same way that the police officer does not make himself liable to attack. Combatants fighting on the just side of a conflict maintain their innocence in the more general sense mentioned above of not being guilty or culpable. McMahan threatens the moral equality of combatants by directly challenging the idea that it is equally morally permissible for combatants on different sides to kill each other: "Those who fight solely to defend themselves and other innocent people from a wrongful threat of attack, and

\footnotetext{
${ }^{33}$ McMahan, Killing in War, p. 14.

${ }^{34}$ Thomas Hobbes, Leviathan, Michael Oakeshott (ed.), (Oxford: Basil Blackwell, 1946), Ch. 14, p. 84.

${ }^{35}$ Hobbes, Leviathan, Ch. 21, p. 142.

${ }^{36}$ I will return to this example in Chapter Two.

${ }^{37}$ For a challenge to this view, see Eleanor Curran, 'Hobbes's Theory of Rights: A Modern Interest View', The Journal of Ethics, Vol. 6, No. 1, 2002, pp. 63-86.

${ }^{38}$ See, for example, John Dunn, The Political Thought of John Locke (Cambridge: Cambridge University Press, 1969), p. 138.
} 
who threaten no one but the wrongful aggressors, do not make themselves morally liable to defensive attack." 39

One could accept that this principle applies generally, yet claim that it doesn't apply in war, which is relevantly different. One might argue that it could be the case that morality is suspended in war or that the moral principles that apply in war are different. ${ }^{40}$ It could be that an example of a different principle that only applies in war is that merely posing a threat is sufficient to be liable to defensive attack. To counter this, McMahan has us consider that a group of unjust combatants begin to violate recognised in bello principles by attacking and killing innocent civilians. ${ }^{41}$ In response to this some of the civilians manage to gather weapons and defend themselves and other civilians from the unjust combatants. This would make them combatants in the moral sense (but not the legal sense) if posing a threat to others is sufficient for liability to attack in war. This would make them legitimate targets for the unjust combatants. It is clear that this is the wrong result. Civilians defending themselves against unjust combatants should not become legitimate targets of the unjust combatants in virtue of defending themselves. This is a case that is clearly analogous to the murderer that McMahan mentions above. However this doesn't fully solve the problem. Contractarians who defend the moral equality of combatants, such as Benbaji, could maintain that there is still a relevant difference between moral combatants and legal combatants. ${ }^{42}$ They could admit that the unjust combatants are not permitted to target the armed innocent civilians. They would then say that because the innocent civilians became combatants only in the moral sense they fall outside of the scope of the Moral Equality of Combatants. Despite its name the moral equality of combatants only extends to the equality between legal combatants. This is because part of what it takes to be a legal combatant is a necessary condition for the symmetry between just and unjust combatants. In particular features such as the training that combatants undergo, the understanding of the role of combatants and the tacit acceptance (particularly when volunteers) that comes through taking on the role of a combatant serve to separate legal combatants from moral combatants. It is because the

\footnotetext{
${ }^{39}$ McMahan, Killing in War, p. 14.

${ }^{40}$ See, for instance, Henry Shue, 'Do we need a morality of War', in David Rodin and Henry Shue (eds), Just and Unjust Warriors: The Moral and Legal Status of Soldiers (Oxford: Oxford University Press, 2008), pp. 87-111.

${ }^{41}$ McMahan, Killing in War, p. 15.

${ }^{42}$ For a more developed contractarian argument for the symmetry thesis, see Yitzhak Benbaji 'The Moral Power of Soldiers to Undertake the Duty of Obedience', Ethics, Vol. 122, No. 1, 2011, pp. 43-73.
} 
civilians do not have this that the unjust combatants are not permitted to kill them, even when they take up arms.

McMahan's arguments above lead him to reject the understanding of 'innocent' as posing a threat and thus the idea of being liable to attack as simply posing a threat. In order to understand being liable to be attacked in relation to being non-innocent McMahan needs to develop another understanding of 'innocent'. Such an alternate understanding of 'innocent' can be found in some of the earlier just war theorists, including Francisco de Vitoria and Francisco Suarez. ${ }^{43}$ Contra Anscombe and Nagel they used it to mean 'not responsible for a wrong' and it was this that was thought to bestow moral immunity from attack. This means that a person may not attack another person in war unless that person has committed a wrong. Such an understanding of 'innocent' enables McMahan to avoid the problems that the murderer example created for the traditional understanding. With this understanding the policeman would not be morally responsible for a wrong and therefore non-innocent, as doing what he is required to do is not committing a wrong. As such he maintains his innocence and is not liable to attack. So for McMahan a person is innocent, and therefore not liable to harm, if that person is neither morally responsible for, nor guilty of a wrong. ${ }^{44}$ McMahan's focus therefore is on moral responsibility and moral responsibility for an objectively unjustified threat of harm. This is the result McMahan wants as it means that he has a criterion of liability to attack that is consistent across cases of war and everyday violence.

\subsection{Benbaji's Response to McMahan}

I am now going to pose a problem for McMahan's account based on Yitzhak Benbaji's 'Sleeping Soldiers' example. The example is quite detailed, so I quote it here in full:

\footnotetext{
"A war has been initiated by an unjust aggression carried out by an elite (and very small) unit of unjust combatants. The preparations for the military campaign were highly confidential. Very few unjust combatants were aware of them. Now, immediately after the surprise attack had been launched, just combatants responded by attacking sleeping enemy soldiers. At the
}

\footnotetext{
${ }^{43}$ For an excellent paper that details how Walzer's developments run contrary to the history of just war theory, see Gregory Reichberg, 'Just War and Regular War: Competing Paradigms', in David Rodin and Henry Shue (eds), Just and Unjust Warriors: The Moral and Legal Status of Soldiers (Oxford: Oxford University Press, 2008)pp. 193-213.

${ }^{44}$ McMahan, Killing in War, p. 34.
} 
time the sleeping soldiers joined the army it was permissible to do so. Additionally, they contributed nothing to the unjust attack, knew nothing about it in advance, and are not responsible for the aggression initiated by their country in any other way. Even so, presumably they will participate in the war. So, their killing is preventive and, as such, a means for achieving a legitimate military goal., $" 45$

I agree with Benbaji that the intuition that the attack on the sleeping soldiers is permitted is very clear. ${ }^{46}$ War has begun and it seems to be common sense the counterattack against what are now unjust combatants is justified. Based on this, Benbaji thinks that this example raises two problems for McMahan that I will discuss in turn.

The first is that it seems that the sleeping soldiers have prima facie not done anything that makes them liable to attack. Because they cannot be morally responsible for the threat of harm they pose (recall that joining the military was permissible - they have done nothing wrong), McMahan's analysis seems to render the result that they are not liable to attack despite being unjust combatants. I will discuss this issue with reference to innocent threats. The second problem is also counterintuitive: If McMahan does argue that the sleeping soldiers are liable to attack then, being unjust combatants, they are denied the right of self-defence. This is "despite the fact that their membership in the military forces is permissible, they are not yet the agents of any threat, and they have had no chance to opt out from the unjust war."47

\subsubsection{Why the sleeping soldiers are like innocent threats and able to be attacked}

As mentioned above, the first problem for McMahan is due to the fact that the sleeping soldiers have not done anything that makes them liable to attack. It is due to the agency of others, namely the government and the elite unit, that they have become unjust combatants. In this sense they are analogous to innocent threats. As we shall see, this is a problem for McMahan as he does not think that it is permissible to attack innocent threats in self-defence precisely because they are not responsible for the threat they pose.

\footnotetext{
${ }^{45}$ Yitzhak Benbaji, 'A Defense of the Traditional War Convention', Ethics, Vol. 118, No. 3, 2008, pp. 464495, at p. 471.

${ }^{46}$ Benbaji, 'A Defense of the Traditional War Convention', p. 473.

${ }^{47}$ Benbaji, 'A Defense of the Traditional War Convention', p. 471.
} 
The problem of an 'innocent threat' was first identified by Robert Nozick in Anarchy, State, and, Utopia and deliberately "tiptoe[d] around". ${ }^{48}$ Nozick defines an innocent threat as "someone who innocently is a causal agent in a process such that he would be an aggressor had he chosen to become such an agent." ${ }^{, 49}$ An example of this type of case is this: A man is pushed by a villain so as to fall onto another man. Falling onto the victim would kill the victim. The only way for the victim to defend himself is to shoot the falling man which would result in the death of the falling man. The falling man is innocent because he was pushed, but he could have been non-innocent if he had deliberately jumped. Nozick does not offer an answer to the question of who is permitted to use force against who in cases like these, merely noting that innocent threats stand apart from regular innocent people (against whom violence is usually prohibited) with different principles applying. ${ }^{50}$ Nozick's use of 'innocent' here aligns with McMahan's use in the sense that it refers to the fact that the falling man is wholly non-responsible for the threat that he poses.

The main reason why McMahan thinks it is impermissible to kill the falling man in selfdefence is because there are no relevant differences between innocent threats and innocent bystanders. ${ }^{51}$ It is thought to be generally impermissible to kill an innocent bystander in self-defence (perhaps through using them as a human shield); consistency demands that it is also impermissible to kill an innocent threat in self-defence. ${ }^{52}$ It is of course true that the bystander is not a part of the threat, yet McMahan has already shown that posing a threat is not sufficient for liability, and this difference is just a relative fact about "position[s] in the local causal architecture" and cannot result in the right not to be killed to be forfeit. ${ }^{53}$ This analysis is problematic for McMahan because when applied to the sleeping soldiers it entails that they are not liable to be attacked as they are innocent threats. This conflicts with our common-sense intuition that the just combatants should be able to attack the sleeping soldiers.

\footnotetext{
${ }^{48}$ Robert Nozick, Anarchy, State, and Utopia (Basic Books, 1974), pp. 34-5.

${ }^{49}$ Nozick, Anarchy, State, and Utopia, p. 34.

${ }^{50}$ Nozick, Anarchy, State, and Utopia, p. 35.

${ }^{51}$ McMahan, Killing in War, p. 170. Also see: Jeff McMahan 'Self-Defense and the Problem of the Innocent Attacker', Ethics, Vol. 104, No. 2, 1994 pp. 252-290; Michael Otsuka, 'Killing the Innocent in Self-Defense', Philosophy \& Public Affairs, Vol. 23, No. 1, 1994. Pp. 79-94.

${ }^{52}$ Exceptions include when the number of people saved by the killing of the bystander are a significant amount. I will assume in my discussion that we are talking about preserving only one life through the death of another.

${ }^{53}$ McMahan, Killing in War, p. 169.
} 
I think that it can be argued that it is permissible to attack the sleeping soldiers. This is done through identifying a relevant difference between innocent bystanders and innocent threats. Helen Frowe and Jonathan Quong both argue that the difference between innocent threats and innocent bystanders has to do with how the victim relates to them and the threat of harm. ${ }^{54}$ Frowe identifies the moral abhorrence of killing the bystander as lying in the fact that when we kill a bystander in order to defend ourselves, we use them in a morally reprehensible way. Using people in this way is clearly impermissible (it is analogous to harvesting an innocent's organs for your own survival ${ }^{55}$ ) and if there is no relevant difference between innocent bystanders and innocent threats, and if it is impermissible to use bystanders as a means then it is also impermissible to use the threats as means. Frowe rejects this implication by identifying a difference between killing a person (innocent bystander) as a means to the end of self-preservation and killing a person (innocent threat) as a means to self-preservation. ${ }^{56}$ It is impossible to use the innocent threat as means to self-preservation because it is their killing which is instrumental to the victim's end. As Frowe says: "Falling person is the threat, and thus cannot also be an instrument in the process of eliminating the threat." ${ }^{, 57}$ Quong draws similar attention to the nature of the innocent threat as the threat. He says that "in killing the Innocent Threat you do not exploit their presence as a means of doing something you could not do without them, but this is what you do in the Bystander cases."

McMahan rejects this suggestion because he thinks that there are cases where the presence of Innocent Bystanders is not exploited as a means to avoid an Innocent Threat yet they are still killed. ${ }^{59}$ For McMahan this is impermissible. A case that illustrates this involves one running through the woods in order to escape a Culpable Threat. ${ }^{60}$ The only way for Victim to escape is to cross a narrow, wobbly bridge. Unfortunately getting onto the bridge would cause the Innocent Bystander to be shaken off and plummet to her

\footnotetext{
${ }^{54}$ Helen Frowe, 'Equating Innocent Threats and Bystanders', Journal of Applied Philosophy, Vol. 25, No. 4, 2008, pp. 277-290; Jonathan Quong, 'Killing in Self-Defense', Ethics, Vol. 119, No. 3, 2009, pp. 507537.

${ }_{55}$ Otsuka, 'Killing the Innocent in Self-Defense', p. 87.

${ }^{56}$ Frowe, 'Equating Innocent Threats and Bystanders', p. 280.

${ }^{57}$ Frowe, 'Equating Innocent Threats and Bystanders', p. 280.

${ }^{58}$ Quong, 'Killing in Self-Defense', p. 526.

${ }^{59}$ McMahan, Killing in War, p. 171.

${ }^{60}$ Variations of this case appear in both McMahan, Killing in War KIW, p. 171, and Quong, 'Killing in Self-Defense', p. 531.
} 
death. It is not possible for the bystander to get off the bridge in time for Victim to get on and escape the Threat. McMahan suggests that running onto, or shaking the bridge in order to dislodge the Bystander, would be examples of killing as a means of selfpreservation, as you are not exploiting their presence by doing something you could not do without them. ${ }^{61}$ Because there is no difference between the way you kill the Innocent Bystander in this case and the way that Innocent Threats were killed above it seems that the relevant difference identified by Frowe and Quong does not apply. Fortunately there is still a way to identify the relevant difference in a way that recognises the impermissibility of killing the Innocent Bystander on the bridge. ${ }^{62}$ Quong argues that people have a prima facie claim to the space they occupy, provided it is not someone else's private property. ${ }^{63}$ Quong identifies this intuition as being motivated by the similar claim that "people have presumptive claim-rights over their body" ${ }^{64}$ Without rights over their body or the space that their body occupies people would lack the most basic requirements for human agency. This is because without such rights we would not be able to limit others using our body for their own purposes, essentially becoming tools of others. This consideration allows us to determine that running onto, or shaking the bridge in order to dislodge the Innocent Bystander is impermissible because Victim would violate the claim that the Innocent Bystander has to the space they occupy on the bridge. This is despite the fact that the Bystander is not occupying the whole bridge, for the precarious nature of the bridge is such that it makes sense to treat it as a piece of space that can only accommodate one person at a time. So despite McMahan's objections otherwise, the distinction of Frowe and Quong do not entail that it is permissible to run onto the bridge. This qualification allows Quong to propose the following counterfactual as a means of determining whether the killing of an innocent person, $X$, would be permissible: "if $X$ and all the things currently belonging to $X$ were suddenly to disappear, would your life be saved?" 65 It is plausible to think of the things that $\mathrm{X}$ has a claim right to as belonging to $\mathrm{X}$. If the answer to the question is yes, then you do not exploit $\mathrm{X}$ by killing them, as you keep what you would have, namely your life, without them. But if

\footnotetext{
${ }^{61}$ McMahan, Killing in War, p. 171.

${ }^{62}$ Frowe simply denies that the Innocent Bystander on the Bridge is in fact a bystander. Rather she identifies obstructors as threats, because they make victims worse off by their presence. See Helen Frowe, 'Threats, Bystanders and Obstructors', Proceedings of the Aristotelian Society, Vol. 109, No. 3, 2008, pp. 345-351.

${ }^{63}$ Quong, 'Killing in Self-Defense', p. 528.

${ }^{64}$ Quong, 'Killing in Self-Defense', p. 528.

${ }^{65}$ Quong, 'Killing in Self-Defense', p. 529.
} 
the answer is no, then you do exploit $\mathrm{X}$, as you cannot survive without the presence of them or things over which they have a rightful claim. As Quong says, you would be shifting "the harm of death from yourself onto $\mathrm{X}$ by using $\mathrm{X}$ 's entitlements against them." 66 As this would be using $X$ as a means to your own survival it would be impermissible.

McMahan would be concerned by this result, because it runs contrary to his account of liability to attack, which states that one must be morally responsible for an unjust threat. However I do not think he needs to be too concerned. This is because it is possible for him to take the position that Nozick suggests in that different principles of self-defence apply to innocent threats. So McMahan could maintain his account of liability to attack as applying to all those who are non-innocent, and accept that a different account, which sits parallel to his own, applies to those threats who are innocent. That different account could be expressed by Quong's counterfactual question, or it might require further development. I do not have the space here to fully discuss alternate accounts for the permissibility of killing innocent threats; however it is sufficient to point out that such an account does not in of itself threaten McMahan's overall account of liability to attack. ${ }^{67}$

This solves the first problem Benbaji poses with the sleeping soldiers example because if the sleeping soldiers are innocent threats then it would be permissible for the just combatants to attack them, as they would not be using them as a means to ensure their own survival. The addition of an extra condition pertaining to innocent threats to McMahan's account engenders an analysis that is consistent with the common-sense intuition that it is permissible for the just combatants to attack the sleeping soldiers.

\subsubsection{Why the sleeping soldiers are permitted to defend themselves}

I think that the analysis employed when solving the first problem enables us to solve the second problem too. Recall that the second problem consists of accepting that if it is permissible to attack the sleeping soldiers, which I have argued it is, then it seems that McMahan's analysis would deny them the right to defend themselves, despite their innocence. Solving the problem means showing why they would be permitted to defend themselves.

\footnotetext{
${ }^{66}$ Quong, 'Killing in Self-Defense', p. 529.

${ }^{67}$ For a principle that would allow for the permissibility of killing innocent threats, see Quong, 'Killing in Self-Defense', p. 530.
} 
Benbaji argues that in innocent threat cases both the victim and the threat are permitted to defend themselves by attacking and killing the other. This is because Benbaji thinks that both the victim and the falling man "lose their right not to be attacked but retain their right to self-defense. ${ }^{\prime 68}$ Benbaji here identifies that in cases of self-defence we possess two rights. There is the claim-right that we have against others not to be killed and there is the liberty-right we possess that allows us to act in self-defence. So Benbaji is saying that in Innocent Threat cases where neither party is responsible for the harm that will be committed, and is thereby innocent, then the situation is one of moral equality. Each party loses their claim-right but both retain their liberty-right. This analysis is also supported by Quong. ${ }^{69}$ I agree with the conclusion but disagree with the specifics of the analysis. It is not correct to say that each party loses their claim-right not to be killed by the other because neither of them have done anything to waive or forfeit that right. Instead it is correct to say that conditions are such that it is permissible for each to override the claim-right of the other. This is consistent with McMahan's account of liability to attack that was outlined above. One set of morally significant conditions that are required for rights to be overridden (rather than violated) is the inevitable prospect of an indivisible harm for which neither party are responsible for. The harm is indivisible because it cannot be shared. If it were the case that a collision between an innocent threat and a victim would result in both being bruised then that would be the fair result. However in most innocent threat cases it is stipulated that someone will die. Death is an indivisible harm that cannot be shared in the way that bruises can; one person has to suffer all of the harm. So the correct analysis of the situation is that both parties retain their right to self-defence yet it is permissible for their claim-right to not be attacked to be infringed by the other party.

The next issue is how the solutions to the problems raised by sleeping soldiers bears on the independence and the symmetry theses.

\footnotetext{
${ }^{68}$ Benbaji, 'A Defense of the Traditional War Convention', p. 477.

${ }^{69}$ Quong, 'Killing in Self-Defense', pp. 520-22.
} 


\subsubsection{Implications of sleeping soldiers for the independence and symmetry theses}

Benbaji thinks that the sleeping soldiers case demonstrates a moral equality of combatants, thereby asserting the symmetry thesis. ${ }^{70}$ This is correct, to the extent that in the example both sides are permitted to use defensive force against the other side. Yet this is only going to be problematic for McMahan if wars typically generate situations like sleeping soldiers, because if this is the case it will result in his analysis being generally irrelevant. So the question becomes: how often in war it is the case that the soldiers on the unjust side are innocent threats, analogous to the example of the sleeping soldiers. Following Walzer, Benbaji asserts the independence principle and argues that that responsibility lies with the leader of the political community. ${ }^{71}$ Because the responsibility lies elsewhere the unjust combatants "are not the agents of the threat they pose, so they are not culpable for it." ${ }^{, 72}$ Further, Benbaji claims that this helps explain why the killings of unjust combatants in an aggressive war are defensive, and therefore permissible. ${ }^{73}$ This is because of the nature of the situation immediately prior to a war. At that moment, combatants on both sides threaten each other: "And since at least some unjust combatants are not even minimally culpable for the initial threat they pose, the defensive threat posed to them is also unjust. ${ }^{, 74}$ Those unjust combatants are, according to Benbaji, permitted to eliminate this threat, despite losing the right not to be attacked through posing an unjust threat themselves.

Unfortunately for Benbaji his account here has at least two flaws. The first flaw is that he relies too heavily on the independence thesis drawing responsibility away from the soldiers. Whilst it is true sleeping soldiers lack any responsibility for the unjust threat they pose, this is not the case generally. In sleeping soldiers and the innocent threat examples there was no way that the threat could be plausibly attributed to the agency of the threateners. This does not generally apply in war, as most soldiers have some control over their actions. It is true that they are subject to military discipline and perhaps other forms of coercion, but at best this will give them a partial excuse (partial because they retain some control) for the threat that they pose. It will not result in the clean moral

\footnotetext{
${ }^{70}$ Benbaji, 'A Defense of the Traditional War Convention', p. 481.

${ }^{71}$ Benbaji, 'A Defense of the Traditional War Convention', p. 481.

${ }^{72}$ Benbaji, 'A Defense of the Traditional War Convention', p. 481

${ }^{73}$ Benbaji, 'A Defense of the Traditional War Convention', p. 482.

${ }^{74}$ Benbaji, 'A Defense of the Traditional War Convention', p. 482.
} 
equality between innocent threats and innocent victims that is required for each to be permitted to attack the other. Benbaji cannot stipulate responsibility away when it is the very thing we are trying to determine. So whilst it is probably true that unjust combatants are not fully responsible for the threat they pose, they are not innocent in the sense highlighted by sleeping soldiers.

The second flaw with his account is that he fails to distinguish between potential and actual threats. It is trivially true that combatants on both sides potentially threaten each other. When ordinary people walk past each other in the street they potentially threaten each other, though the probability of the threat being actualised in these cases is much lower. It is not permissible to invoke this potentiality as a justification for defensive action in the future. ${ }^{75}$ This justification is particularly problematic when used by a party to justify subsequent attacks after they had instigated the conflict with aggressive action. So Benbaji's attempt to show how the moral equality present in sleeping soldiers generalises does not succeed.

There is one concerning implication that sleeping soldiers raises however. If the sleeping soldiers didn't find out that it was actually their side who unjustly initiated the war then it is easy to see that they would think they are permitted to keep on fighting. They would (incorrectly) see themselves as being the just combatants having suffered an unjust attack whilst they were sleeping. In this instance it seems that they are very much like innocent threats as they are being manipulated by their commanders. The commanders are like the villainous pusher in the innocent threat case in that they are manipulating innocent people into being unjustified threats. The villainous man pusher uses facts about Falling Man, such as his weight, in order to fulfil his unjust aims. Similarly the commanders use facts about the men, mainly their willingness to fight against an unjust threat, in order to pursue their own unjust aims. But this is only problematic if the aim of just war theory is to mitigate the harm of war as such an incentive will serve to perpetuate harm through incentivising epistemic deceit. McMahan, with his focus on identifying morally permissible defensive action would not change the theory to mitigate the bad outcomes.

\footnotetext{
75 The exception here is a preventive action which relies on a high probability of the potential threat occurring in order to be permissible.
} 


\subsection{Why unjust combatants are unable to satisfy the discrimination requirement}

I will now change focus slightly and look at the implications of McMahan's arguments for the symmetry thesis. I particular I will look at how unjust combatants are able to satisfy the in bello principle of discrimination. McMahan thinks that his arguments that show why the traditional understanding of the criterion of liability to attack is mistaken also prevent unjust combatants from meeting the principle of discrimination, which he identifies as the central principle of jus in bello. This is problematic for the moral equality of combatants as the in bello principles are supposed to be neutral between just and unjust combatants. The traditional view of Just War Theory holds that once a war has started, meeting the in bello conditions should not be more difficult for unjust combatants. McMahan argues that this is mistaken and unjust combatants are (nearly always) unable to satisfy the principle of discrimination.

The reason that unjust combatants fail to satisfy the principle of discrimination is because they lack legitimate targets. The traditional understanding of the discrimination requirement identifies only noncombatants as illegitimate targets. This is because noncombatants are thought to be innocent in the sense that they are non-threatening. McMahan's position has the implication that just combatants are not legitimate targets, because people do not forfeit their right against attack and become legitimate targets "simply by offering violent resistance to unjust attacks by unjust combatants.",76 McMahan thinks that in the same way that the police officer maintains his innocence, just combatants also maintain theirs. This means that as they innocent they are not legitimate targets and attacking them, as unjust combatants are wont to do in a war, would thereby violate the principle of discrimination.

McMahan does not think that just combatants are incapable of becoming legitimate targets. He identifies one example when it is permissible for unjust combatants to intentionally target just combatants: when just combatants pursue their legitimate aims through impermissible means. ${ }^{77}$ One example of this would be through intentionally attacking innocent people as we saw in the bombing campaign conducted by the Allies

\footnotetext{
${ }^{76}$ McMahan, Killing in War, p. 16.

${ }^{77}$ McMahan, Killing in War, p. 16.
} 
near the end of World War II. These impermissible actions made the pilots at least morally liable to defensive attack as they became "legitimate targets even for unjust combatants. ${ }^{, 78}$ An analogous case might be if the policeman in the murderer case fired intentionally at innocent people who had come in between the policeman and the murderer. The policeman has the legitimate aim of targeting the murderer but if he targets innocents in pursuit of this aim then he makes himself liable to be harmed. Whilst it is important to note this exception, in the overall context of assessing the permissibility of killing in war it is of negligible importance as an unjust war cannot predominantly consist of acts that work to prevent wrongful acts of war by combatants. ${ }^{79}$ This is because prosecuting a war would have to involve acts that are not reactionary. It is difficult to imagine how a war could progress by only preventing unjust acts by just combatants. Advancing an unjust cause would have to involve acts that are not merely responses to the acts of the enemy. For instance it seems that it would be difficult for the Axis to have restricted their war against the Allies to simply stopping their unjust bombings of cities. This is especially so because a war like this would primarily be a war of self-defence (i.e. defending their own civilians) and an unjust war, which is typically aggressive, is not going to primarily consist of defensive acts. The fact that unjust combatants are generally going to be unable to satisfy the in bello principle of discrimination shows that the symmetry thesis is false as it highlights that a proper understanding of liability to attack results in just and unjust combatants having different in bello rights and obligations. The fact that these differences are a result of the unjust combatants advancing an unjust aim, an ad bellum consideration, shows that the independence thesis is false as it demonstrates that in bello judgements are influenced by ad bellum considerations. Because the two theses that constitute the moral equality of combatants are false, it should be rejected.

\subsection{Hurka's Response to McMahan}

Thomas Hurka is in agreement with McMahan regarding his analysis of the murderer case and its application to war. ${ }^{80}$ So he thinks that simply posing a threat is not sufficient for a person to be morally liable to attack. But Hurka does not think that this is the most persuasive justification of the moral equality of combatants. He thinks that volunteer

\footnotetext{
${ }^{78}$ McMahan, Killing in War, p. 16.

${ }^{79}$ McMahan, Killing in War, p. 17.

${ }^{80}$ Thomas Hurka, 'Liability and Just Cause', Ethics \& International Affairs, Vol. 21, No. 2, 2007, pp. 199218.
} 
armies provide a better justification. This is because through "voluntarily entering military service, soldiers on both sides freely took on the status of soldiers and thereby freely accepted that they may permissibly be killed in the course of war." ${ }^{\text {} 81}$ Hurka thinks that the situation of combatants is very similar to that of boxers who waive their rights to be permissibly attacked by specific people - the opposing fighter. Combatants accept the permissibility of being killed by enemy combatants in the course of a battle. Part of this acceptance involves the condition that the enemy combatants accept the reciprocal permissibility that they may be killed also. An important feature of the combatant's waiver is that it, according to Hurka, is done with no regard to the justice of either sides cause. $^{82}$ This has the important implication that their moral status with respect to each other is the same; they waived their rights and became combatants equally. Hurka highlights what he takes to be one important difference to the Boxer example in that combatants give up their right globally. Whereas boxers give up their rights in very specific, limited circumstances, combatants give up their rights in all future wars. I think that this difference is only a matter of scale. A combatant also gives up his rights in very specific, limited circumstances - in the theatre of war as opposed to everyday life. It is also not entirely global as combatants retire, as do boxers. They both get their rights back then. The difference is actually slightly different to what Hurka identifies. He says that the combatant waives the right not to be harmed. But the combatant actually abnegates the right to determine when to fight. He gives up the autonomy to choose which wars he fights in. This is something that the boxer does not do when he decides to fight. Now the person who is a combatant can regain this autonomy to choose when he fights, but only by quitting and not fighting in a war. This would thereby make the person no longer a combatant, as part of what it means to be a combatant (a volunteer one at least) is that the decision as to which wars they take part in is not up to them. ${ }^{83}$ This is made more explicit, as Hurka points out, when we see that combatants who refuse to fight in a war can be prosecuted for desertion. I am assuming that combatants who resign before being deployed will not be prosecuted for desertion, even though they might face other costs.

Hurka considers a serious objection to his view which says that in many cases people become combatants in a way that is not fully voluntary, either through conscription or

\footnotetext{
${ }^{81}$ Hurka, 'Liability and Just Cause', p. 210.

${ }^{82}$ Hurka, 'Liability and Just Cause', p. 210.

${ }^{83}$ In democratic countries at least, civilian control of the military is strictly adhered to.
} 
having no other career options: "How can these soldiers have voluntarily surrendered their right if their joining the military was forced?" 84 Hurka identifies two responses to this. First is the 'hard-line' response which says that in all of these cases there is an element of choice, such as the choice to go to prison in protest, or leave the country, which entails that entering the military is still voluntary. Even this limited level of voluntary choice is sufficient, so the hard-line response says, "to involve a full surrender of rights." 85 In contrast, the "soft-line' response accounts for differential status of combatants. For combatants who are forced into joining the military the soft-line view can give greater weight to their potential deaths when entering into proportionality calculations. Further to this, when it comes to assessing the extent to which conscripts have given up their rights, the soft-line view can say that whilst volunteer combatants are able to permissibly be attacked at any stage of a war, conscripted combatants are only able to be when they are a "sufficiently imminent threat." threat in this context means that the conscripted combatants have the status of innocent threats. The implication of this is that the only time they are liable to attack is when they are engaged in actual fighting. Conscripted combatants would not be liable to attack when sleeping in their barracks and otherwise disengaged from combat.

Hurka ultimately refrains from choosing between the hard-line and soft-line views, but I don't think either view provides a successful defence of the waiver account. This is because I don't think that the moral responsibility for your actions can be fully abnegated. Whilst it is true that we can relinquish decision making, it is not so obvious that we can relinquish responsibility. Denying responsibility for a voluntary action would deny an essential part of what it means to be a person. Further, it is not clear that the analogy with the boxer holds up. When two boxers step into the ring they each know that the other has waived their right. This is not necessarily the case in war, especially when we consider that many of the actual motivations for people joining an army are directly related to $a d$ bellum considerations. If people feel their country is fighting an unjust threat, this can be sufficient to motivate them to fight. And if the reason for their joining the army is based on an assessment of ad bellum principles it is incorrect to say that they give up the right to decide those matters when they join; their ad bellum conclusions were what led them

\footnotetext{
${ }^{84}$ Hurka, 'Liability and Just Cause', p. 213.

${ }^{85}$ Hurka, 'Liability and Just Cause', p. 213.

${ }^{86}$ Hurka, 'Liability and Just Cause', p. 215.
} 
to fight in the first place. To spell it out clearly: if civilians join the army because they wish to prevent the enemy unjustly invading their country it is clear that they do not consent to being attacked by the enemy. The reason they joined the army was to prevent the enemy threatening them, not the complete opposite! So for these reasons I think that Hurka's response to McMahan does not succeed in establishing the moral equality of combatants.

\subsection{Conclusion}

This chapter has introduced and examined both the moral equality of combatants and McMahan's criticisms of it. I have argued that McMahan shows that the traditional conception of liability to attack - posing a threat - is inadequate. I have also argued in response to Benbaji that McMahan's account should be modified in order to be able to account for innocent threats. Understanding McMahan's account of liability to attack enabled me to outline why unjust combatants are unable to satisfy the in bello requirement of discrimination. This discussion demonstrated why the independence and symmetry theses are false and subsequently that the moral equality of combatants is to be rejected. Finally I looked at Hurka's response to McMahan and argued that it failed. In the next chapter I will look at McMahan's contribution to the development of the proportionality requirement, an area where Hurka has also contributed. 


\section{Proportionality}

McMahan's revisionist criticisms of just war theory lead him to significantly modify the jus in bello requirement of proportionality. In this chapter I will look at McMahan's developments in the context of prior modifications by Thomas Hurka, and a subsequent critique by David Rodin. Traditionally this requirement of proportionality has said that combatants may only use force that is proportional to the end that they seek. McMahan argues that determining proportionality requires the evaluation of more factors (such as liability and intention) than simply measuring the amount of harm against the good achieved. His revisions come after his rejection of the moral equality of combatants, which leads him to argue that unjust combatants also have difficulty satisfying the proportionality condition. This is because as unjust combatants they will typically be advancing unjust aims that will be difficult to justify. My discussion will first set out the traditional understanding of proportionality, before moving on in the second section to discuss Hurka's widely accepted revision that clarifies the goods and evils taken into account. The third section will look at McMahan's account. The fourth section will explore Rodin's critique of McMahan where I will argue that his incorporation of significantly many more factors in the proportionality calculation is closer to the correct view. Finally I will consider a general problem for both McMahan and Rodin's revisions of proportionality.

\subsection{The Traditional Understanding of Proportionality}

Just war theory has traditionally distinguished between an ad bellum and an in bello proportionality requirement. The ad bellum requirement holds that resort to war is impermissible if the relevant good effects of the war are outweighed by the bad effects. ${ }^{87}$ An example of a war that might not be proportional would be one that would be predicted to be a gruelling war of attrition with high rates of innocent casualties on both sides over a disputed patch of worthless territory. ${ }^{88}$ The in bello requirement makes

\footnotetext{
${ }^{87}$ An example of a relevant good effect of a war would be advancing the just cause.

${ }^{88}$ This example is modified from one found in Jeff McMahan, 'Just Cause for War', Ethics \& International Affairs, Vol. 19, No. 3, 2005, pp. 1-21, at p. 4.
} 
similar claims about individual acts in a war. Henry Sidgwick explains that it is impermissible to do "any mischief which does not tend materially to the end [of victory], nor any mischief of which the conduciveness towards the end is slight in comparison with the amount of mischief." 89 This is supposed to prohibit excess (or disproportional) harm through appealing to two criteria. The first is the criterion of necessity, which many authors think is a separate in bello principle. Hurka tells us that "killing soldiers and especially civilians is forbidden if it serves no military purpose". ${ }^{90}$ So even though unjust combatants are liable to harm, if harming them does not further the aim of the war then that harm is not permissible. The second criterion is a more explicit proportionality requirement. According to Sidgwick we are required to weigh the mischief done against its contribution towards winning the war. It is pertinent to note that it is only the contribution to the military advantage which is assessed here, not the ultimate purpose of the military action. An important issue in interpreting this criterion is determining who counts when weighing up mischief, as traditionally not everyone has.

Both ad bellum and in bello cases assume that the principle of discrimination (whereby it is only permissible to attack legitimate targets, i.e. combatants in the traditional understanding) is already applicable and so "the relevant bad effects are generally only assumed to include only unintentional harms to the innocent" as intentional harms to the innocent are already ruled out. ${ }^{91}$ Similarly, harms to those who are liable to suffer them have traditionally played no role in proportionality requirements. An implication of this last point is highlighted by Hurka: if justified combatants can prevent an attack by unjustified combatants that would kill only one civilian on the side of the justified combatants, then they are permitted to "kill virtually any number of any soldiers" in order to save the one civilian. ${ }^{92}$ It is not clear if this proportionality result, when the deaths of only one or two civilians are anticipated, would apply to ad bellum deliberations around starting a war. The reason for this is that it is uncertain that opposition combatants count as being liable to attack prior to the war beginning. If they do not count as liable to attack then it seems that their predicted deaths would weigh against military action, but if they do count then their predicted deaths would not enter

\footnotetext{
${ }^{89}$ Henry Sidgwick, in Walzer, Just and Unjust Wars, p. 129.

${ }^{90}$ Thomas Hurka, 'Proportionality in the Morality of War', Philosophy \& Public Affairs, Vol. 33, No. 1, 2005, pp. 34-66, at p. 36.

${ }_{91}^{91}$ McMahan, Killing in War, p. 18.

${ }^{92}$ Hurka, 'Proportionality in the Morality of War', p. 58.
} 
calculations and military action would be more likely. However it does seem clear that under the traditional view, once the war has begun enemy combatants are committed to being morally liable to attack and so they play no role in proportionality deliberations. ${ }^{93}$ This means that those who do weigh in proportionality calculations are citizens and combatants on your side and any potentially foreseen but unintended harm to enemy (and neutral) noncombatants. ${ }^{94}$ Walzer gives the example of General Roberts who, during the battle of Paardeberg in the Boer War, called off assaults on Boer trenches, saying that the casualties "did not appear ... to be warranted by the exigencies of the situation." " His main consideration was the lives of the soldiers under his command, not enemy soldiers.

\subsection{Hurka's Account of Proportionality}

Hurka sees both the ad bellum and in bello proportionality requirements as saying that a war or an act in a war is wrong "if the relevant harm it will cause is out of proportion to its relevant good."96 The questions for Hurka then become: what are the relevant goods and evils that count in a proportionality requirement? ${ }^{97}$ Hurka does not think that it is plausible to weigh the goods and evils equally such that a war is proportionate if the total good of the war outweighs the total evil, as James Turner Johnson advocates. ${ }^{98}$ It is similarly implausible for Hurka if the goods are weighed more heavily than the evils, such that a war can be proportionate even if it causes more harm than good, as the US Catholic Bishops and Douglas Lackey argue. ${ }^{99}$ The main problem that Hurka sees with both these views is that they count in their calculations all the goods that a war will produce. As an example, Hurka asks us to imagine a war that is fought with a just cause where one of the good outcomes will be lifting the nation out of recession. Despite the very real economic benefits of a war (World War II effectively ended the depression of the 1930s) it does not seem appropriate that these benefits count towards the justification

\footnotetext{
${ }^{93}$ Remember of course that the necessity requirement is also thought to be applicable here. So it still has to be necessary to kill that solider in order to save the civilian for each soldier to be killed.

94 McMahan thinks that proportionality typically only takes into account unintentional harms to the innocent. Justified combatants would count as innocent under his definition.

${ }^{95}$ General Roberts, in Walzer, J\&UW, p. 130.

${ }^{96}$ Hurka, 'Proportionality in the Morality of War', p. 38.

${ }^{97}$ Hurka, 'Proportionality in the Morality of War', p. 38.

${ }^{98}$ James Turner Johnson, Can Modern War Be Just? (New Haven: Yale University Press, 1984), p. 62.

${ }^{99}$ US Catholic Bishops 'The Challenge of Peace' in Elshtain, Jean Bethke (ed.), Just War Theory (Oxford: Basil Blackwell Ltd, 1992), pp. 77-168, at p. 101; Douglas Lackey The Ethics of War and Peace (Englewood Cliffs, N. J.: Prentice-Hall, 1989), pp. 40-41.
} 
of war. ${ }^{100}$ Similarly, other benefits that can come from war, such as technological advancement or the satisfaction of desires of soldiers, do not seem relevant to proportionality. Hurka proposes a restriction on the goods that count towards proportionality - "the relevant goods are only those contained in the just causes." ${ }^{\prime 101}$ It is only the goods that come from achieving the just aims of a war that count towards its proportionality. According to Hurka this stipulation frees us from a problem with Johnson's account in that it does not require that a war have overall good effects. So a war would not be disproportionate if the money a war cost could have been spent alleviating poverty in another part of the world, but it would be disproportionate if there was a less destructive way to achieve the war aim. ${ }^{102}$ In his formulation Hurka draws on McMahan and Robert McKim in distinguishing between sufficient and contributing just causes. ${ }^{103}$ The existence of a sufficient just cause satisfies the just cause condition by itself. Examples of these include the standard just causes: resisting aggression, the prevention of major humanitarian atrocities, and so on. In contrast to sufficient just causes, contributing just causes do not by themselves fulfill the just cause requirement. It is only when there is a sufficient just cause that contributing causes come into play. So whilst a contributing just cause might be the disarmament of an enemy, a nation can only pursue this if there is a sufficient just cause that enables it. On its own the contributing cause cannot justify military action. Hurka asks whether there is some contributing feature that allows us to identify a contributing just cause. He cannot identify any, allowing that "like the sufficient just causes, they are just the items on a list," 104 and that the limits are only intuitive ones.

Hurka's analysis of in bello proportionality draws on his arguments regarding ad bellum proportionality. When justifying a particular act in a war we must look at whether it contributes to the just causes, either sufficient or contributing, through increasing their likelihood or degree of achievement. ${ }^{105}$ As in the ad bellum case, acts leading to the satisfaction of a contributing just cause will only be permissible if that cause is relevant through being enabled by a sufficient just cause. Hurka sees the in bello proportionality

\footnotetext{
${ }^{100}$ Hurka, 'Proportionality in the Morality of War', p. 40.

${ }^{101}$ Hurka, 'Proportionality in the Morality of War', p. 40.

${ }^{102}$ Hurka, 'Proportionality in the Morality of War', p. 41.

103 Jeff McMahan and Robert McKim, 'The Just War and the Gulf War', Canadian Journal of Philosophy Vol. 23, No. 4, 1994, pp. 501-41, at pp. 512-513.

${ }^{104}$ Hurka, 'Proportionality in the Morality of War', p. 43.

${ }^{105}$ Hurka, 'Proportionality in the Morality of War', p. 44.
} 
requirement as taking into account another consideration, namely the relevant good of an act contributing to reducing the cost of achieving a war's just causes. ${ }^{106}$ As an example of this Hurka considers an act that will foreseeably result in the deaths of more civilians when compared with another that will reduce either the economic costs of the act or the number of military casualties. Sometimes it will be required to accept the greater cost to prevent the deaths of enemy civilians, but Hurka argues that this consideration is not unlimited: "we cannot be required to sacrifice hundreds of soldiers or spend billions of dollars to save a few enemy civilians." ${ }^{107}$ I shall argue in Chapter Four that some civilians will be responsible for the war in a way that makes them liable to attack. If this is correct then greater costs will not be required to protect enemy civilians. Hurka also realises that his arguments run counter to traditional just war theory. In requiring in bello proportionality to be sensitive to ad bellum proportionality he is rejecting the independence of the ad bellum and in bello principles. He also thinks that the varying moral importance of the just cause influences in bello permissibility. So a war of extreme moral imperative such as that against Nazi Germany will permit a greater level of destruction than say the Falklands War, even though both wars would be justified. ${ }^{108}$ This leads Hurka to the conclusion that soldiers fighting to advance an unjust cause can never act permissibly as they will never satisfy the in bello proportionality requirement. It should be noted that Hurka does not think that they should be punished as "soldiers normally cannot be expected to evaluate their nations' war aims, they are not to blame for acting wrongly.",109

When Hurka turns to determining the relevant evils applicable to proportionality, he finds no restriction on their content that is parallel to the restriction on relevant goods. So, the fact that a war will benefit the economy does not count in its favour, but the fact that it harms the economy "surely counts against it." 110 Similarly hindering scientific development, or the pain of combatants who fight counts against a war. Therefore, when assessing the proportionality of a war "we count evils of all the kinds it will cause, with

\footnotetext{
${ }^{106}$ Hurka, 'Proportionality in the Morality of War', p. 44.

${ }^{107}$ Hurka, 'Proportionality in the Morality of War', p. 44.

${ }^{108}$ Hurka, 'Proportionality in the Morality of War', p. 44. For more on this point, see Michael Walzer, 'World War II: Why Was This War Different?', in Cohen, Marshall, Nagel, Thomas, and Scanlon, Thomas (eds), War and Moral Responsibility (Princeton: Princeton University Press, 1974), pp. 85-103.

${ }^{109}$ Hurka, 'Proportionality in the Morality of War', p. 45.

${ }^{110}$ Hurka, 'Proportionality in the Morality of War', p. 46.
} 
no limits on their content." 111 There is a worry that this view allows for a proliferation of evils to be considered which includes things that no political leader would consider in a proportionality calculation simply because they do not seem to be relevant. For instance in a later paper, Hurka mentions that a relevant evil would be the hindrance or destruction of art. ${ }^{112}$ In a proportionality calculation where we are weighing up the goods and evils of a war the goods that are most likely in play are those that come from satisfying the just cause(s). It just does not seem right to say that things like destruction of art, or scientific research, count towards determining proportionality in the same way as the satisfaction of a just cause or the prospect of human atrocities.

Hurka also attempts to answer the question of responsibility for third party evils. Hurka claims that just as with relevant goods, the temporal or causal remoteness of a relevant evil to either a war or an act does not seem to be relevant. ${ }^{113}$ The fact that evil in the future will occur as a direct result of my action, for example through a war increasing instability in a region, or predictably resulting in conflict between other third parties, does not mean that it does not weigh in our proportionality requirements. However what does seem to reduce the weight of the above mentioned evil in a proportionality requirement is when the responsibility for the harm seems to lie with another agent. Hurka considers a case where an agent's defence against an attacker will lead to increased attacks on others, maybe because the attacker will vent his rage on weaker victims. ${ }^{114}$ The responsibility for the resulting attacks, though they would not have occurred without the agent's defence, surely lies with the attacker and not with the agent. It is extremely implausible that we could be held responsible for the independent actions of another. ${ }^{115}$ The fact that the responsibility for the evil lies elsewhere minimises the weight that the evil has in a proportionality calculation. However Hurka refuses to commit to whether or not the wrongful choices of others can reduce our responsibility for bad outcomes. Rather he notes that there is a range of views ranging from another's wrong choice removing our responsibility for an action (thereby giving it zero weight in a proportionality calculation), to the agency of others having no relevance whatsoever to the weight an evil has in our proportionality calculations (thereby giving it full

\footnotetext{
${ }^{111}$ Hurka, 'Proportionality in the Morality of War', p. 46.

112 Thomas Hurka, 'Proportionality and Necessity', in Larry May (ed.), War: Essays in Political Philosophy (Cambridge: Cambridge University Press, 2008), pp. 127-144, at p. 135.

${ }^{113}$ Hurka, 'Proportionality in the Morality of War', p. 46.

${ }^{114}$ Hurka, 'Proportionality in the Morality of War', p. 46.

${ }^{115}$ Independent in the sense that they are not coerced by, or acting on behalf of, another agent.
} 
weight). ${ }^{116}$ There are also intermediate views where evils that depend on others agency only diminish the weight of an evil, or only diminish the evil in some cases and not others - say when the choice is made by the person who will suffer the evil. ${ }^{117}$

\subsection{McMahan's Account of Proportionality}

In contrast to Hurka, McMahan has a more nuanced understanding of the proportionality requirements that enables him to develop a more comprehensive analysis of proportionality justifications. ${ }^{118} \mathrm{He}$ is in agreement with Sidgwick as to the function of the proportionality requirement: "Proportionality is a constraint on action that causes harm." 119 Typically, for an act that causes harm to be justified it must be instrumental to the achievement of some goal against which the harm can be compared. McMahan labels the goal of an act of war a 'war aim'. The main difference between Hurka and McMahan is that McMahan thinks there is more to proportionality calculations than simply weighing the harms and benefits of an action against the war aim. In particular he emphasises the importance of liability and intention as two factors that affect how we understand different types of proportionality requirements regarding harm. ${ }^{120}$ With these factors in play McMahan is able to identify four different proportionality requirements with reference to four different types of acts: ${ }^{121}$

i. Acts that intentionally harm those who are potentially liable to be harmed in the pursuit of some war aim.

ii. Acts that unintentionally but foreseeably harm those who are potentially liable.

iii. Acts that intentionally harm those who are not potentially liable.

iv. Acts that unintentionally but foreseeably harm those who are not potentially liable.

This account is innovative because it outlines factors that are important to consider when determining if a harm is proportionate. The introduction of these new factors also makes it an improvement because it allows us to more accurately understand proportionality. It

\footnotetext{
${ }^{116}$ Hurka, 'Proportionality in the Morality of War', p. 49.

${ }^{117}$ Hurka, 'Proportionality in the Morality of War', pp. 49-50.

${ }^{118}$ In Killing in War McMahan focuses on in bello proportionality, yet claims that his account could apply, with modifications, to ad bellum proportionality (McMahan, Killing in War, p. 19)

${ }^{119}$ McMahan, Killing in War, p. 19.

${ }^{120}$ McMahan, Killing in War, p. 19.

${ }^{121}$ McMahan, Killing in War, p. 19-20.
} 
introduces features that are important to justifications of harm that are not captured through simply weighing up the harm. When philosophers discuss proportionality in war they typically consider cases that are linked with the fourth kind - weighing unintended harms against noncombatants with the war goals an act would further. This is contrasted with the first kind of proportionality which is that usually discussed when considering cases of self-defence. McMahan considers an actual case of individual self-defence to draw out the differences.

\subsubsection{The Goetz case; narrow vs. wide proportionality}

In 1984 on the New York Subway Bernhard Goetz shot four men who had crowded around him demanding money in a menacing way. In shooting the men he caused one to suffer brain damage and permanent paralysis, and seriously wounded the other three. McMahan claims that the four men were potentially liable to attack because they threatened Goetz. However Goetz's actions also harmed the other people on the subway, as there was the risk that he might miss his assailants and hit other commuters. These people were not potentially liable to attack, as they had done nothing to threaten Goetz. This difference in liability allows McMahan to distinguish two types of proportionality. Narrow proportionality pertains to harms directed at someone who is potentially liable to be harmed and is contrasted with wide proportionality which pertains to harms directed at someone who is not potentially liable to any harm. ${ }^{122}$ Narrow proportionality aligns with $i$. and $i i$. above, whereas wide proportionality aligns with iii. and $i v$. It is important to note that the liability has to be related to the aim of the harm. So a thief would be potentially liable to some harm in defence of property but this liability would not transfer to the case of war. Assuming that theft is his only wrongdoing the thief is not potentially liable to harm in pursuit of a war aim, despite being liable in another situation. Liability to harm is context specific. The focus on liability means that the narrow/wide distinction does not identify differences in intentionality. McMahan nevertheless thinks that intention is a relevant factor and suggests that we should expect proportionality requirements to be more stringent for harms that are intentionally inflicted when compared with those that are unintentionally inflicted. ${ }^{123}$

\footnotetext{
${ }^{122}$ McMahan, Killing in War, pp. 20-21.

${ }^{123}$ McMahan, Killing in War, p. 21.
} 


\subsubsection{Narrow proportionality}

McMahan thinks that the harm Goetz inflicted on the four men was narrowly disproportionate because they would probably have left Goetz unharmed if he had simply given them the five dollars and if he had refused there was a low probability they would have seriously harmed him. ${ }^{124}$ However the men were potentially liable to some sort of defensive action and McMahan suggests that a proportionate response might have been a rap over a threatening hand with a truncheon (if Goetz had had one) such that it broke the fingers of the aggressor. This is an interesting result for McMahan. For he seems to be suggesting that innocent people can be liable to suffer minor or even moderate harm when attacked even if they have the means to defend themselves. The reason it is unusual is that it suggests that the permissibility of defensive action is contingent on the means at the defenders disposal. So, how the defender armed himself in the morning, whether with a pistol, as Goetz did, or with a truncheon, as McMahan suggests would have been appropriate, affects the permissibility of defensive action. This is problematic as it implies that in order for people to be adequately equipped to permissibly defend themselves they should carry an array of weapons with which to distribute the appropriate proportionate defensive harm. Further to this, when we realise that situations where self-defence is called for are typically heated and rushed, the idea that a range of defensive weapons to be selected at the appropriate moment after considering what type of response is proportionate is what is required for permissible defensive action to be taken seems absurd.

This is not to argue that Goetz's actions were permissible. I think that they were not, but for different reasons to McMahan. Goetz's actions were disproportionate in a preengagement sense, equivalent to a situation where the relevant principles are jus ad bellum. The actions of the aggressors are analogous to the manoeuvrings of a country before engaging in war. Asking Goetz for money in a threatening tone is perhaps equivalent to stationing troops on a border. Goetz's response to this of shooting the youths was disproportionate in the same way that dropping bombs on the stationed troops would be. They are both disproportionate because they escalated the situation into an actual conflict. In neither of these examples had an attack actually happened nor is there an imminent threat. It is clear that in both cases there is a potential threat of harm, but

${ }^{124}$ McMahan, Killing in War, p. 21. 
this is not the same thing as an imminent threat. Goetz's action was disproportionate because it started a physical altercation, not because it was disproportionate in the context of the situation. After being asked for money the appropriate and proportional response would have been to prepare for a potential attack, perhaps by politely refusing whilst reaching for his gun. Similarly in the border case the appropriate response to having troops stationed on the border is for a state to prepare to defend itself, perhaps by also posting troops. However once attacked Goetz would be permitted to use his weapon as through actually threatening Goetz they would have made themselves liable to be attacked in that manner.

A problem with my response is that it appears to identify Goetz as the aggressor even though he was the one approached and threatened by the youths. We can avoid this problem by using Suzanne Uniacke's distinction between potential aggressors and actual aggressors. $^{125}$ The four men who started the interaction were only potential aggressors. To be actual aggressors they would have to act on their intention to harm. I do not think that the four men acted on any intention to harm, even if that intention was there. It is of course true that the potential threat they posed was unjust, and as such Goetz was permitted to respond in some kind. As suggested above, a proportionate response by Goetz would have been a potential threat of harm; displaying his gun to demonstrate that the initial threat of harm would be unwise to carry out. A disproportionate response to the potential threat does not make Goetz the initial aggressor even if his actions escalated the conflict. ${ }^{126}$ Many wars are the result of tit-for-tat escalations where it is difficult to determine the aggressor yet in this case it is clearly the four men who instigated the conflict. Alternatively Goetz could claim that he felt that the men, in extending their hands as part of their demands, constituted an imminent threat. Many cases of potential harm constitute a grey area where it is extremely difficult to determine whether or not the case in question is an imminent threat or not. The grey area consists of indeterminacy about the likelihood that the potential harm will lead to actual harm and also about how harmful that will be. To sufficiently determine this it is required to assess a range of factors including the degree of harm threatened, the probability of it actually occurring,

125 Suzanne Uniacke, Permissible Killing: The self-defence justification of homicide (Cambridge: Cambridge University Press, 1994), p. 70.

${ }^{126}$ Uniacke suggests that the 'aggressor' is not always the instigator of the conflict. If the instigator sincerely attempts to withdraw and then the initial victim unreasonably continues the conflict then it is appropriate to label the victim as the aggressor (Uniacke, Permissible Killing, p. 71). In the Goetz case however the four men did not attempt to withdraw and so they remain aggressors. 
the ability of the defensive agent to prevent the harm now, the ability of the defensive agent to minimise the harm once the aggressive agent causes it, and so on. I will address problems relating to having to assess all these factors below.

\subsubsection{Wide proportionality}

As mentioned above Goetz's actions also harmed the other commuters on the subway. Because this was unintentional it means that Goetz's act was also an example of $i v$. as he unintentionally harmed those who were not potentially liable to any harm. ${ }^{127}$ McMahan thinks that his actions here were also disproportionate, though this time in the wide sense, because he imposed risks that were "excessive in relation to the threat he faced from the four men." ${ }^{128}$ Undertaking such assessments involves making what amounts to lesser evil or necessity judgments and indeed this is the function that McMahan sees wide proportionality as having. In contrast with narrow proportionality, which is a constraint on liability justifications for harm, wide proportionality is a constraint on lesser evil justifications for harm. ${ }^{129}$

These lesser evil justifications apply to iii. where those who are not potentially liable are intentionally targeted. This is the case even though the requirement of discrimination, which forbids the targeting of illegitimate targets, applies. ${ }^{130}$ But many just war theorists do not believe that the requirement of discrimination is absolute. Walzer, for instance, thinks that in conditions of supreme emergency it can be permissible, and perhaps even required, to violate the requirement of discrimination. ${ }^{131}$ The implication is that if the requirement of discrimination is not absolute, then when it is overridden becomes a matter of proportionality. The benefits that will enter into a proportionality calculation regarding iii. (where those not potentially liable are intentionally targeted) will have to be very substantial if the act is to be allowed.

\footnotetext{
${ }^{127}$ McMahan, Killing in War, p. 21.

${ }^{128}$ McMahan, Killing in War, p. 21.

${ }^{129}$ Jeff McMahan, 'Proportionality in the Afghanistan War', Ethics \& International Affairs, Vol. 25, No. 2, 2011, pp. 143-154, at p. 146.

${ }^{130} \mathrm{I}$ am assuming that a person who is not liable to attack in pursuit of a war aim is an illegitimate target in that war.

${ }^{131}$ Walzer, Just and Unjust Wars, ch. 12. For a discussion of some recent terrorist actions that were not justified and some instances where terrorist attacks would have been justified but were not used, see Saul Smilansky, 'Terrorism, Justification, and Illusion', Ethics, Vol. 114, No. 4, 2004, pp. 790-805.
} 


\subsubsection{Application of proportionality}

It is commonly assumed that when applying the proportionality requirement to war the only aspect that is relevant is what McMahan has classified as wide proportionality. It is peculiar that narrow proportionality, which plays a major role in individual cases of selfdefense, does not have an equally important role in war. McMahan identifies the reason for this as lying in the traditional view of just war theory, which maintains that during war all combatants are liable to any harm that may come from military attack. As any harm to which a person is liable is necessarily proportionate, all attacks on military personnel are proportionate. As all attacks are proportionate there is no place for deliberation regarding the narrow proportionality requirement and so it is ignored. Because McMahan disagrees that all combatants are liable to attack he has to include narrow proportionality in his analysis of unjust combatants. He argues that unjust combatants cannot be proportionate in either the narrow or the wide sense except when they are preventing just combatants from acting wrongly. This is because for narrow proportionality to apply the person suffering the harm has to be potentially liable. McMahan has argued that just combatants do not become liable to attack simply by fighting or posing a threat. Therefore under McMahan's analysis attacks on just combatants come under the scope of wide proportionality. Most of the actions of unjust combatants will contribute to the unjust war aim. This means that they will not be contributing to any good outcomes to weigh against the bad outcomes of killing those not potentially liable to attack. Because of this McMahan thinks "attacks by unjust combatants against just combatants ... are in practice very unlikely ever to be proportionate in the wide sense." ${ }^{132}$

\subsection{Rodin's Response to McMahan}

McMahan's development of the concept of proportionality consists in identifying that the factors of liability and intention are relevant in determining whether different acts are proportionate. Rodin takes this idea further and argues that we need more factors than those McMahan identifies to provide an adequate account of proportionality. He also argues that we should understand the relationship between the various factors in a different way to McMahan. He argues that we should not try and identify different types of acts that feature all the factors as that is overly complicated, but rather we should

${ }^{132}$ McMahan, Killing in War, p. 27. 
understand proportionality judgments as consisting of the relationship between the different factors, which are the normative status of the acts of agents.

It is curious that McMahan does not introduce more factors himself. In two recent papers McMahan indicates that he is also aware of other factors relevant to proportionality judgements, yet maintains the distinction between narrow and wide proportionality. ${ }^{133}$ In particular he argues that how bad side effects (in wide proportionality) are caused is a factor that affects the permissibility of the action. ${ }^{134} \mathrm{He}$ also indicates that determining liability to defensive harm (i.e. in narrow proportionality) involves factors such as the degree of moral responsibility for the threat and how the threat would be reduced by the defensive harm. ${ }^{135}$ So it seems that McMahan is aware that more factors are relevant in proportionality calculations than the two he prioritises. Rodin develops this point by pointing out that whilst McMahan is correct in identifying the importance of the intention of the defending agent (D), he ignores the intentions of the attacking agent (A), which also must be relevant. ${ }^{136}$ Fitting these different factors into McMahan's structure of proportionality acts would quickly result in a complicated proliferation of acts that accounted for each of the various combinations of relevant factors. Rodin proposes something slightly simpler. He thinks that all justifications for harm, including liability and lesser evil justifications, should be conceived as a "relationship between the normative status of the acts of agents." 137 Determining the normative status involves considering both the factors that McMahan introduces as well as others that he has omitted. Rodin identifies a total of 14 factors with eight relevant to the threatening agent and six relevant to the defending agent. ${ }^{138} \mathrm{I}$ do not have space to fully discuss all 14 factors so I will limit discussion to factors where I disagree with Rodin's analysis. I will mention the most important factors in Section 2.4.4 when I discuss how the factors work together to produce justifications for harm. Overall I do think that Rodin's approach here is the right one. Justifying harm is not a simple endeavour, and his approach allows for the complex factors that are relevant to be considered.

\footnotetext{
${ }^{133}$ McMahan, 'Proportionality in the Afghanistan War'; Jeff McMahan, 'Who is Morally Liable to be Killed in War', Analysis, Vol. 71, No. 3, 2011, pp. 544-559. In 'Who is Morally Liable to be Killed in War' McMahan lists six different factors relevant to determining liability (p. 548). I criticise four of the factors in Section 3.2 .

${ }^{134}$ McMahan, 'Proportionality in the Afghanistan War', p. 147-8.

${ }^{135}$ McMahan, 'Proportionality in the Afghanistan War', p. 152.

${ }^{136}$ David Rodin, 'Justifying Harm', Ethics, Vol. 122, No. 1, 2011, pp. 74-110, at p. 78.

${ }^{137}$ Rodin, 'Justifying Harm', p. 80.

${ }^{138}$ Rodin, 'Justifying Harm', pp. 80-1.
} 


\subsubsection{Justification of the Threatened Harm}

The first factor I will look at is the justification for the threatened harm. In particular, this includes harms that are not proscribed, and are therefore justified, by moral or legal norms. This category encompasses typical side-effect and externality harms. ${ }^{139}$ Rodin has us consider as examples the harm of congestion that a driver contributes to, or the harm to a competitor by a shopkeep's competitive pricing. These are harms that are not proscribed and do not generate defensive rights.

Rodin thinks that this category of harms provides a solution to McMahan's case of the conscientious driver. ${ }^{140}$ In this case, a driver of a vehicle, which is meticulously maintained, decides to drive to the movies. The driver always drives with care, yet on the way to the cinema the vehicle is subject to a freak event that could not have been anticipated which results in the car veering out of control in the direction of a pedestrian. ${ }^{141}$ Given the fact that it is known that driving "carries a small risk of causing great though unintended harm" McMahan argues that the driver carries some responsibility for the harm imposed upon the pedestrian. McMahan sees this responsibility as sufficient for the driver to be liable to defensive action to prevent the killing of the pedestrian.

Rodin argues against what he terms an "intuitively uncomfortable result." ${ }^{142}$ He thinks it can be avoided it we distinguish between "responsibility for imposing the risk of harm and responsibility for the harm itself." 143 It is true that the driver is responsible for imposing the risk of harm to the pedestrian. But because the driver had taken due care to offset the risk, imposing the risk was not proscribed. As we have seen above, nonproscribed risks are not risks that people have a right against. It is true that what the pedestrian does have a right against, being struck by a car, is something that is proscribed, but Rodin argues that this is not an action that the driver is responsible for. ${ }^{144}$ The stipulation that it is a freak event that causes the threat of harm is important. It seems to suggest a mechanical failure or something comparable. Rodin thinks that such an event

\footnotetext{
${ }^{139}$ Rodin, 'Justifying Harm', p. 84.

${ }^{140}$ I discuss this case in more detail in Chapter 4.

${ }^{141}$ McMahan, Killing in War, p. 165.

${ }^{142}$ Rodin, 'Justifying Harm', p. 85.

${ }^{143}$ Rodin, 'Justifying Harm', p. 85.

${ }^{144}$ Rodin, 'Justifying Harm', p. 85.
} 
would then be analogous to cases of physical compulsion like Nozick's falling fat man. ${ }^{145}$ This seems right when we compare it with a case where the freak accident was due to the driver's inexcusable negligence. This would leave the driver with, at best, an agency defeating excuse which would more plausibly entail that he be liable to defensive harm - the result McMahan argues for.

However this result is unsatisfactory for a reason Rodin does not consider. The reason is that a distinction of this sort does not help the pedestrian decide what is an appropriate response. Consider the pedestrian walking down the street, also going to the cinema. He hears a loud bang and turns to see the vehicle hurtling towards him. Being a mechanic, he knows that loud bangs can be indicative of freak events. However it could be representing a freak event of the type that Rodin thinks the driver is non-responsible for, or it could be a freak event of the type that the driver is responsible for. The situation does not allow the pedestrian to ascertain which of these two options is the cause of his current predicament. Having read Rodin's paper he knows that the driver is only liable to defensive harm if he was not responsible for the freak event. But as he has no way of knowing this he does not know if he is permitted to defend himself. This is only a problem if one thinks that it is not permissible to defend yourself against innocent threats (as both McMahan and Rodin do). If one thinks that you are able to defend yourself against innocent threats, then the problem does not arise. ${ }^{146}$ It is interesting to note that only in the case where the driver is not responsible for the initial threat of harm, e.g. where he is an innocent threat, is the driver permitted to defend himself from the pedestrian's defensive harm. If the driver has responsibility for the initial threat of harm, suppose that the vehicle was out of warranty and he had recently become aware of a serious manufacturing defect, then he is not permitted to defend himself.

\subsubsection{Causal and Temporal Proximity to the Threatened Harm}

The second factor I am going to look at is the temporal and causal proximity of the attacking agent $\mathrm{A}$ to the threatened harm. Liability to defensive harm is typically subject to a requirement of temporal imminence. It rules out both preventive harm that is

\footnotetext{
${ }^{145}$ Rodin, 'Justifying Harm', p. 85. I discussed this case in more detail in Section 1.2.

${ }^{146} \mathrm{I}$ argued for this in Section 1.2.1.
} 
"significantly prior" 147 to the threatened harm and defensive harm inflicted on a past aggressor. An example of the latter case would be one where D suffers from a life threatening organ failure that was culpably inflicted by A a year ago. Rodin thinks that it is not clear that $\mathrm{A}$ is liable to be killed for organ harvesting by $\mathrm{D}$, even if that was the only way of D's life being preserved. ${ }^{148}$ Similarly, causal proximity is also a typical restriction on liability to defensive harm. Rodin gives us an example where A is a cutler. ${ }^{149}$ Supposing that A made a knife which was then used by a third party to threaten the life of D most people believe that A would not be liable to be killed even if that were the only way to prevent the attack.

Rodin thinks there is little doubt that causal and temporal proximity affect liability. However there lies a crucial question in whether they are relevant only because of their relevance to the responsibility of A or if they play an independent role. This question is important because it has implications as to whether noncombatants can ever be permissible targets in war.

I am unconvinced as to the importance of causal and temporal proximity in diminishing liability. This is because in regards to the cutler case, I think the intuition is best explained with regards to the type of harm that the cutler poses and not the causal distance. The reason that there is an intuition against harming the cutler is because of the factor discussed above - the act of making of a knife is a non-proscribed harm and as such does not generate defensive rights. We might have a different intuition (where the cutler would be liable to be killed if it was the only means to prevent an attack) to a modification of the cutler case that Rodin mentions in a footnote, where the cutler fashions a special blade with the direct intention of it being able to penetrate D's special armour. ${ }^{150}$ Rodin attributes this different intuition to the cutler's direct intention to harm but it seems equally plausible that there is a prohibition on creating (and using) weapons with the particular purpose of harming innocent individuals.

I also do not think temporal proximity is as important as Rodin thinks it is. Imagine a case where a farrier is walking to visit the cutler. The farrier inadvertently sets off a

\footnotetext{
${ }^{147}$ Rodin, 'Justifying Harm', p. 89.

${ }^{148}$ Rodin, 'Justifying Harm', p. 89.

${ }^{149}$ Rodin, 'Justifying Harm', p. 90.

${ }^{150}$ Rodin, 'Justifying Harm', p. 90, fn 20.
} 
bomb that was planted by the person who is trying to kill $\mathrm{D}$. The only way for $\mathrm{D}$ to prevent his imminent death is through killing the farrier. It seems that it ought to be that $\mathrm{D}$ is able to kill both the farrier in this case and the cutler in the special blade case. This is despite the supposedly relevant difference of temporal proximity. Temporal proximity is not a relevant factor in liability to harm if that harm is the only way to prevent death. The reason that temporal proximity seems like it diminishes liability to harm is because it is hard to escape the notion that as more time passes the responsibility is diminished. This is due to the fact that over time more options become available for others to influence events and for alternate options to be taken. But if it is stipulated that acting against the cutler is the only way to avert an attack then we should be consistent and reject the purported relevance of temporal proximity.

\subsubsection{Probability of the Defensive Harm Averting the Threatened Harm}

The next factor I am going to discuss is the probability of the defensive harm averting the threatened harm. If there is an extremely low probability that D's action (of inflicting defensive harm on A) is likely to succeed in averting the threatened harm then it seems that this will diminish A's liability to that defensive harm. ${ }^{151}$ The jus ad bellum principle of likelihood of success is the representation of this factor. If there is no likelihood of success in averting the threatened harm "then there is no liability." 152

Rodin discusses an objection of Daniel Statman that brings out the focus of a liability account - the interaction of agency between different persons. Statman claims that this principle as puzzling. ${ }^{153}$ Supposing that a woman with two bullets in a gun is about to be attacked and raped by five men, he argues that she would be permitted to use the bullets and kill two of the men despite the fact that she would still face rape from the other three. Rodin counters this by reminding us that each of the men is individually liable to be killed "because this measure would succeed in averting their rape." ${ }^{154}$ Rodin identifies Statman's concerns as having more force in cases of hopeless defence against a single assailant. In cases like these it seems odd to say that a victim would not be permitted to

\footnotetext{
${ }^{151}$ Rodin, 'Justifying Harm', p. 92.

${ }^{152}$ Rodin, 'Justifying Harm', p. 92.

${ }^{153}$ Daniel Statman, 'On the Success Condition for Legitimate-Defense', Ethics, Vol. 118, No.4, 2008, pp. 659-686.

${ }^{154}$ Rodin, 'Justifying Harm', p. 92.
} 
break an arm of the assailant even though this would not prevent the rape. Rodin identifies two factors that could explain this. First, it could be that delaying the infliction of a threatened harm can provide a basis for liability - even when preventing the harm is ultimately not possible. ${ }^{155}$ Second, when we talk about there being no prospect of success, we actually mean a very low prospect (this is similar to my discussion of proximity). And conversely when compared to the magnitude of the defensive harm, lower probabilities of success are justified when there is an increase in factors relevant to the threatening agent, especially when the aggressive harm threatens innocent life and the integrity of a person. Rodin suggests that if it were the case that inflicting defensive harm on A would not "prevent, delay, or ameliorate the threatened harm in any way" then it would be difficult to see how A could be liable to defensive harm. ${ }^{156}$ Whilst this might be true in a thought experiment, fortunately it is difficult to conceive a real world scenario where all of these factors were both satisfied and known with absolute certainty by D, and as such it seems likely that D would typically be permitted to inflict defensive harm upon A.

\subsubsection{How the Factors Work Together}

Rodin takes the 14 factors to work together to produce both liability and lesser evil justifications of defensive harm. In either case $\mathrm{A}$ is liable to defensive harm/has a lesser evil justification from $\mathrm{D}$ if and only if the combination of factors relevant to A exceeds, in the relevant way, the combination of factors relevant to D. ${ }^{157}$ The important issue is how to determine the relevant way the factors interact. A difference between lesser evil and liability justifications is the factors that constitute necessary and sufficient conditions. For liability justifications, two factors that are relevant to A are necessary conditions: 3. Responsibility for the threatened harm and 4. Justification of the threatened harm. A must be responsible for the threatened harm and the threatened harm must either be unjustified or be a violation of rights. ${ }^{158}$ For lesser evil justifications, two different factors relevant to A are necessary: 1. Magnitude of the threatened harm and 2. Probability of the threatened harm occurring. These act as necessary conditions for lesser evil justifications. Rodin also identifies one factor relevant to D as a sufficient condition for a lesser evil justification: 9. Magnitude of the defensive harm. This is a

\footnotetext{
${ }^{155}$ Rodin, 'Justifying Harm', p. 93.

${ }^{156}$ Rodin, 'Justifying Harm', p. 93.

${ }^{157}$ Rodin, 'Justifying Harm', p. 96.

${ }^{158}$ Rodin, 'Justifying Harm', p. 98.
} 
sufficient condition when the harm is zero because "when D can avert a threatened harm without inflicting any harm at all, then it is necessarily a lesser evil and this is sufficient for justification." 159 In both lesser evil and liability justifications, all the other factors are additive in that they increase or decrease the evil or bad effects on either side of the relationship without their presence or absence being necessary or sufficient conditions for justification. ${ }^{160}$

Rodin's analysis is the closest to the correct view on proportionality. It is possible to quibble over the factors that are relevant and the importance particular factors have, as I have done in parts. However this quibbling does not count against Rodin's fundamental insight, which builds upon McMahan's developments, that both narrow and wide proportionality consist of the relationship between the normative status of the acts of agents. Determining whether an act is proportional consists in much more than simply weighing up the harms and benefits of an action as the traditional view advocates. Rather, we should weigh factors relevant to the threatening agent against the factors relevant to the threatening agent. It is important to note that Rodin's analysis relies very heavily upon factors relevant to individual agents that do not analogise cleanly to interstate ad bellum proportionality justifications. However it could be the case that Rodin's approach is also relevant for ad bellum proportionality but with a modified set of factors. This is especially likely if we accept McMahan's assumption that the conditions of permissible moral action are no different in war than in self-defence. This assumption does not hinder Rodin's account here as he is responding to McMahan and thereby working in a similar framework.

\subsection{A Problem with Revised Accounts}

I will finish this chapter with a criticism of the general approach by McMahan and Rodin. The shared feature between the two accounts is the identification of several factors as being integral to a proper understanding of proportionality. A problem with an account where multiple factors are at play is that it is difficult to prescribe a template for agents to follow. Hobbes recognised this difficulty and conceded that only individuals are capable of determining when they are imminently threatened, which is why people

\footnotetext{
${ }^{159}$ Rodin, 'Justifying Harm', p. 98.

${ }^{160}$ Rodin, 'Justifying Harm', p. 98.
} 
cannot give up the right to self-defense from the state. ${ }^{161}$ In Chapter 21 of Leviathan Hobbes declares that "covenants, not to defend a man's own body, are void." 162 This leads Hobbes to accept the implication that: "If the sovereign command a man, though justly condemned, to ... not resist those that assault him, ... that man [has] the liberty to disobey." "163 Though I want to resist the conclusion that even those who are justly harmed retain the liberty to fight back (and I think McMahan's arguments in Chapter One show why this is false) Hobbes' point about each individual being best placed to determine "the aptest means thereunto" defend himself is harder to resist. ${ }^{164}$ This is problematic as it gives instincts an ethical priority that we often want to avoid. Fortunately it is not clear that this worry about instincts applies to states and therefore is not applicable in $a d$ bellum considerations. Unlike Goetz and other cases of individual defence, states are very rarely confronted with potential life or death decisions that require immediate action. This does not mean to say that states do not face imminent threats but rather that the imminent threat for a state is not as pressing as an imminent threat for an individual. States should be held to higher standards of ethical consideration than individuals, as states, generally, have more time to consider the complex factors that are relevant in such a decision, whereas individuals do not and are reliant upon instincts. Indeed, it is plausible that the institutions of states allow for better decision making capacities.

Of course, this response to Hobbes accounts for ad bellum difficulties, but not for in bello difficulties. In the case of in bello concerns it is typical that soldiers trust that many of the factors will have already been decided for them, especially that the magnitude of the threatened harm is grave, and that there is no justification for the threatened harm. This division of labour means that it should be easier for combatants, than ordinary noncombatants to satisfy proportionality requirements, provided (and this is a big 'provided') the state that they serve makes morally permissible decisions. This is because some of the factors will already be ticked for them. Ultimately I do not accept the criticism that the proliferation of factors is unhelpful. This is because it already seems that just war theory has something similar in that various factors such as necessity,

\footnotetext{
${ }^{161}$ At the beginning of Ch. 14 he says: "The right of nature ... is the liberty each man hath, to use his own power ... for the preservation of his own nature; that is to say, of his own life; and consequently, of doing any thing, which in his own judgement, and reason, he shall conceive to be the aptest means thereunto." (Hobbes, Leviathan, Ch. 14, p. 84.)

${ }^{162}$ Hobbes, Leviathan, Ch. 21, p. 142.

${ }^{163}$ Hobbes, Leviathan, Ch. 21, p. 142.

${ }^{164}$ Hobbes, Leviathan, Ch. 14, p. 84.
} 
discrimination and so on need to be satisfied in order for an act to be permissible. Further, in the majority of cases the factors are going to be relatively clear. For instance it is likely a defendant will know whether they are responsible for the harm they face, or whether there are any pre-existing duties of care. ${ }^{165}$ The most difficult cases, where there are epistemic concerns are going to be problematic for most other justifications of defensive harm as well - it is everyman's problem. It is also everyman's problem in the sense that it is difficult to analyse what is permissible defensive conduct, and Rodin's analysis seems to me to be a big step in towards determining the answer.

\subsection{Conclusion}

In this chapter I have looked at the development of proportionality from the traditional view to Hurka, and then the radical developments of McMahan and Rodin who develop the insight that there is more to proportionality than weighing up harms and benefits. I have argued that Rodin's approach to proportionality, which involves weighing up multiple normative factors, is the closest thing to the right view. Some of the issues raised in this chapter have wider implications. In particular I will be looking further at one of Rodin's necessary conditions for liability justifications, the attacking agent's responsibility for the unjust threat of harm, in closer detail in Chapter Four.

${ }^{165}$ These are factors 12 . and 14. in Rodin's analysis. 


\section{Lazar's Responsibility Dilemma}

Lazar agrees with McMahan regarding his rejection of the moral equality of combatants. However Lazar finds fault with McMahan's alternate theory of liability to be harmed, the responsibility account. The reason for this is that he thinks that it might have implications that most would reject. ${ }^{166} \mathrm{He}$ thinks that the responsibility account is subject to two objections, the contingent pacifist objection and the total war objection, which taken together constitute two horns of a 'Responsibility Dilemma'. The dilemma rests on the claim that many unjust combatants have the same level of responsibility for the threat of harm as unjust noncombatants. Lazar develops this to argue that if some unjust combatants are not liable, due to not being sufficiently responsible, then just combatants are required to discriminate between the unjust combatants and their differing degrees of responsibility. As this requires epistemic access that is near impossible, it seems that though fighting a just war may be a theoretical possibility; in practice we should be pacifists. Avoiding this horn of the dilemma is going to require setting the liability bar low. This then opens up the responsibility account to the total war objection by allowing many noncombatants to be intentionally targeted and killed. This chapter will proceed by first setting out the dilemma. This will involve explaining why unjust combatants and unjust noncombatants have a similar level of responsibility and then setting out in more detail the two horns. Second, I will argue that McMahan's attempt to clarify his account of liability fails. This is because of problems with the factors he introduces that are independent of responsibility. In the third section I will consider responses to the contingent pacifism horn by McMahan, who focuses on counterfactuals and luck, and Strawser, who focuses on epistemic difficulties. In the fourth and final section I will consider three responses to the total war horn; the negligible contribution of unjust noncombatants; the justified contribution of unjust noncombatants and the ineffectiveness of targeting noncombatants. I will argue that all of these responses fail and that the dilemma stands.

${ }^{166}$ Lazar, 'The Responsibility Dilemma for Killing in War', p. 187. 


\subsection{The Responsibility Dilemma}

The force of the responsibility dilemma lies in Lazar's claim that many noncombatants have a similar level of responsibility for the threat in war as combatants. The first part of this section will show how Lazar establishes that claim.

A key component of McMahan's responsibility account is that merely posing a threat is neither sufficient nor necessary for liability to defensive harm. ${ }^{167}$ This is because one can pose a threat without being agent-responsible for it, for example if a person was rendered unconscious and used as a projectile. One can also be responsible for a threat without actually posing it, perhaps by using another as a projectile. Rather, it is responsibility for the threatened harm, which must be objectively unjust, that grounds liability to attack. However the presupposition that some causal contribution is required to be responsible for the threat remains. The problem that Lazar identifies is that "it is unclear how to measure that contribution, and how its size affects the degree of responsibility." "168 Here is an example to illustrate this: Suppose homeowner $\mathrm{H}$ commissions tradesman $\mathrm{T}$ to install a platform on H's property from which $\mathrm{H}$ can shoot game. $\mathrm{H}$ is severely disabled with limited movement and so part of the commission involves setting a gun up and sighting it, and loading it. When $\mathrm{H}$ prepares to use the gun for the first time he notices his nemesis $\mathrm{N}$ who has wandered onto his land and is in the gun's sights. All that is required for $\mathrm{H}$ to shoot $\mathrm{N}$ is to pull the trigger (as $\mathrm{T}$ sighted and loaded the gun). $\mathrm{H}$ shoots $\mathrm{N}$ and kills him, which, we can stipulate, was objectively wrong. It seems that the majority of the responsibility for this threat lies with $\mathrm{H}$; he is maximally morally responsible and blameworthy. Yet $\mathrm{T}$ made a significantly larger causal contribution to the threat than $\mathrm{H}$ he constructed the platform, loaded the gun and sighted it! At most, we can say that $\mathrm{T}$ is agent-responsible, as his voluntary actions contributed to the threat. The point is that a significant causal contribution to a threat does not by itself translate to significant moral responsibility for that threat. If one thinks that pulling a trigger is a significant causal contribution, then consider a mafia boss who hires a hit man to kill a target. The degree of the boss's causal contribution is negligible; asking a person to pose a threat is markedly different than physically using a person as a projectile threat. The point here is that even though it seems a causal contribution is required in order to be responsible for a

\footnotetext{
${ }^{167}$ McMahan, Killing in War, p. 157.

${ }^{168}$ Lazar, 'The Responsibility Dilemma for Killing in War', p. 190.
} 
threat, it is difficult to evaluate the degree of the casual contribution with respect to responsibility.

Lazar acknowledges that despite this difficulty many will think that the fact that combatants make a larger causal contribution to the unjust threat than uncombatants is a relevant difference when determining different levels of responsibility. Lazar responds to this by simply arguing that if there is a difference, it is not universal. That is: "many combatants make small and unnecessary causal contributions to micro- and macrothreats, and as such are similarly positioned to many noncombatants." ${ }^{169}$ Micro-threats are those that threaten individuals, whereas macro-threats are those which a state poses to its opponent. ${ }^{170}$ An agent can contribute to either of these threats in two ways, by either being the agent of the threat or contributing towards a threat that is posed by another. ${ }^{171}$ Lazar argues that many combatants are "wholly ineffective in war", making little to no contribution to micro-threats or to the larger macro-threat, due in large part to combatants" "natural aversion to killing". ${ }^{172}$ Of those who make a little contribution, many of them can only be said to facilitate the threat, through being a cook, medic, and so on. As such they are making small contributions to micro-threats, and even smaller contributions to the overall macro-threat. Lazar concludes that many of the contributions made by unjust combatants are going to be small and unnecessary. This is a problem for McMahan, for if small and unnecessary contributions to unjust threats are sufficient for liability to attack in war, then many more noncombatants than seems plausible (McMahan is open to some noncombatants being liable to attack ${ }^{173}$ ) are going to be liable to attack. Many noncombatants make individually small and unnecessary contributions to the threat posed by their side in a war. These include direct contributions such as taxes, supplying military necessities, and rationing. They also include indirect contributions such as building the state's capacity, giving it the strength to focus on a war, providing it with legitimacy through voting and even contributions made towards giving combatants skills such as those a maths teacher imparts to a future gunner. ${ }^{174}$ Indeed in a modern

\footnotetext{
${ }^{169}$ Lazar, 'The Responsibility Dilemma for Killing in War', p. 190.

${ }^{170}$ Lazar, 'The Responsibility Dilemma for Killing in War', p. 186.

${ }^{171}$ Lazar, 'The Responsibility Dilemma for Killing in War', p. 190.

${ }^{172}$ Lazar, 'The Responsibility Dilemma for Killing in War', pp. 190-1.

${ }^{173}$ McMahan, Killing in War, pp. 213-8. As a specific example he gives the real life case of the United Fruit Company executives who had a decisive role to play in the 1954 invasion of Guatemala by the United States (McMahan, Killing in War, pp. 214, 221-222).

${ }^{174}$ Lazar, 'The Responsibility Dilemma for Killing in War', p. 192.
} 
state it seems that almost every person contributes in some way to the capacity of the state to act. Though these contributions are small and unnecessary, that does nothing, Lazar concludes, to distinguish them from the contributions of many combatants. If those combatants are sufficiently responsible then it seems so are noncombatants. ${ }^{175}$

\subsubsection{Why epistemic problems support contingent pacifism}

Lazar also focuses on the excuses that might be available to unjust noncombatants. This is important as excuses work to reduce the culpability of agents. If the actions of unjust combatants are excused then for it to be permissible to target them, the liability bar must be set low. They will still be liable, as they will presumably have some responsibility for the objectively unjust threat that they pose, but it may only be appropriate to attribute agent-responsibility to them. As we shall see below, this opens the door for the other horn of the dilemma, the total war objection.

Lazar states that combatants have an epistemic excuse when they are nonculpably ignorant of the fact that they contribute to an unjust threat. ${ }^{176}$ This means that their mistaken beliefs are going to be sufficiently epistemically justified given the circumstances. ${ }^{177}$ Lazar argues that McMahan fails to take into account factors such as uncertainty and reasonable partiality that "lower the epistemic burden on combatants". ${ }^{178}$ A key factor here is the indeterminacy of both moral and non-moral principles. Whilst there may be areas of general agreement, real wars tend to take place on the "fuzzy edges of these areas". ${ }^{179}$ Wars also often feature new technologies such as poison gas, nuclear weapons, or drones that are introduced and used at a pace that outstrips the typically staid pace of academic thought. If experts are unable to agree on the relevant moral principles facing soldiers, then it seems unreasonable to expect soldiers to do so. Even if there were clear moral principles it is common and easy for the nonmoral facts to be obscured or even manufactured. ${ }^{180}$ This is especially true of states determined to wage war. A classic example of this is the Gleiwitz incident, the Nazi staged attack that was used to justify invading Poland. Democratic and non-democratic governments alike have a chequered

\footnotetext{
${ }^{175}$ Lazar, 'The Responsibility Dilemma for Killing in War', p. 193.

${ }^{176}$ Lazar, 'The Responsibility Dilemma for Killing in War', p. 193.

${ }^{177}$ Lazar, 'The Responsibility Dilemma for Killing in War', p. 193. Lazar clarifies that "a belief is fully epistemically justified when it is decisively supported by the available evidence ... [and that it is] partially justified when ... some of relevant evidence is unexamined, or ambiguous."

${ }_{178}^{178}$ Lazar, 'The Responsibility Dilemma for Killing in War', p. 194.

${ }^{179}$ Lazar, 'The Responsibility Dilemma for Killing in War', p. 194.

${ }^{180}$ Lazar, 'The Responsibility Dilemma for Killing in War', p. 194.
} 
history of being open and honest about the decisions to go to war. ${ }^{181}$ Granted, there might be good reasons for secrecy, such as protecting intelligence sources, but this does not help combatants decide whether the war their country is preparing to launch is just or not.

Supposing that a combatant is able to determine that they have a just cause, they encounter further epistemic difficulties. For in order to fight justly combatants need to determine who is liable to be killed and to do that they need to know the degree of responsibility their opponent has for the threat posed. Lazar lists what is required for just combatants to determine, often in the heat of battle, about each of their opponents: “[T]hey must know at least their adversaries' personal histories, the context of their decision to fight, their connection to a particular threat, their capacity for responsible agency, [and] their beliefs and intentions". ${ }^{182}$ Determining this, Lazar claims, "is near impossible."

Another aspect that Lazar argues can lower the epistemic burden that combatants must meet to be excused is that of reasonable partiality. This is because wars often endanger those closest to us and our country. Lazar thinks that this is relevant to the level of epistemic burden we reasonably set for unjust combatants because "when the costs of a mistake could fall so heavily on those that we care about, we should be granted a certain epistemic allowance." 184 The point is not that reasonable partiality justifies intentional wrongs or that it provides a full excuse when known non-liable parties are attacked. Lazar argues instead for the weaker claim that for combatants in conditions of uncertainty as to the justice of their cause "reasonable partiality lowers the degree of credence their belief that their war is justified must meet, in order to afford a full excuse." $" 185$

\footnotetext{
${ }^{181}$ Consider for example the decisions to go to war in Iraq in 2003 by the USA and the UK. For a criticism of the USA's decision to invade Afghanistan in 2001 see Noam Chomsky, Hegemony or Survival: America's Quest for Global Dominance (New York: Henry Holt and Company, 2003), p. 200.

${ }^{182}$ Lazar, 'The Responsibility Dilemma for Killing in War', p. 187.

${ }^{183}$ Lazar, 'The Responsibility Dilemma for Killing in War', p. 187.

${ }^{184}$ Lazar, 'The Responsibility Dilemma for Killing in War', p. 198. Shielding the dangers of war from loved ones and countrymen can be a very powerful motivator. For an example of this, see Ian Kershaw, The End: Germany 1944-45 (Penguin Books, 2012). Throughout his book he contrasts the motivation of the German troops fighting on the eastern front against the Russians with those fighting on the western front against the British and Americans. Stories of Russian atrocities helped to motivate German troops among whom it "was seen as imperative to protect the civilian population from the sort of horror" perpetuated by the Red Army. (Kershaw, The End, p. 270. Also see pp. 100, 223).

${ }^{185}$ Lazar, 'The Responsibility Dilemma for Killing in War', p. 198.
} 
Lazar's arguments work together to show that many more unjust combatants are going to be epistemically excused than McMahan allows. Rather than being culpable for the unjust threats they are only going to be agent-responsible. Setting the liability bar higher than agent-responsibility will therefore result in many unjust combatants not being liable to be killed. Because it is in practice impossible to determine which unjust combatants are liable and which are not (due to either being excused or non-responsible), this renders fighting wars justly practically impossible. ${ }^{186}$ Therefore we reach the conclusion of the contingent pacifism horn; we should be pacifists if it is practically impossible to fight wars justly. To make it permissible to fight unjust combatants, and thereby get around this horn, McMahan needs to set the liability bar of his account low. Unfortunately this opens the door for Lazar's total war horn, which I will set out now.

\subsubsection{The total war horn}

The conclusion of the total war horn is a problem for McMahan because it entails that many unjust noncombatants are liable to attack in war. McMahan thinks he can resist this problem by using narrow proportionality, which as we saw in Chapter Two identifies those who are liable to attack, and by then claiming that unjust noncombatants are not liable to attack. Lazar argues that McMahan applies both the liability bar and just cause (in proportionality calculations) inconsistently with respect to combatants and noncombatants. ${ }^{187}$ Lazar thinks it is likely that within the sets of combatants and noncombatants there will be a range from agent-responsibility to culpability, rather than a clear differentiation of levels of responsibility between the two sets. So some combatants will be (merely) agent-responsible and some non-combatants culpable, and vice versa. This means that in war, when the threat faced is sufficiently serious (it is a war after all!) and lives of just combatants or noncombatants can be saved by killing agent-responsible unjust noncombatants then McMahan's theory, consistently applied, should permit this. ${ }^{188}$ This is because under his account minimal responsibility is sufficient for liability and it is fairer that the unjust noncombatants bear the costs rather the just combatants or just uncombatants who have no responsibility at all for the threat. This means that narrow proportionality cannot be used to protect unjust noncombatants against the total war objection because when properly applied to unjust noncombatants it highlights small, but

\footnotetext{
${ }^{186}$ Lazar, 'The Responsibility Dilemma for Killing in War', p. 202.

${ }^{187}$ Lazar, 'The Responsibility Dilemma for Killing in War', p. 204.

${ }^{188}$ Lazar, 'The Responsibility Dilemma for Killing in War', p. 204.
} 
relevant differences that "make all the difference in the allocation of unavoidable harms." "189

Lazar considers one way that narrow proportionality might protect noncombatants through the distribution of risk. McMahan argues that the less responsible the just combatants' targets are, the more risk the just combatants have to take upon themselves in order to minimise harm to the targets. ${ }^{190}$ So if the targets are culpable, then less risk should be taken than if the targets were merely agent-responsible. The main problem that Lazar identifies here is that whilst this may work in more general cases of distributing harm, in war the risk that is being assumed is always that of being killed. ${ }^{191}$ The problem is that death is an indivisible harm and assuming more risks in order to minimise harm will result in the deaths of non-liable combatants for the benefit of reduced harm to those who are liable. ${ }^{192}$ This is an unacceptable result as it is unfair for those who are nonliable (the just combatants) to bear risks that will increase the likelihood that they will die, in order to reduce the harm that would fall upon those who are liable to receive it (the unjust noncombatants).

So the responsibility dilemma claims that McMahan's responsibility account for liability to attack in war faces an internal dilemma. The first horn, the contingent pacifist horn, argues that unless the liability bar is set low then many unjust combatants will not be liable to attack. However if the bar is set too low then the second horn, the total war horn, arises: many unjust noncombatants will be liable to attack. In the next part of this chapter I will look at responses to the dilemma. I will first look at an attempt by McMahan to distinguish between the liability of combatants and noncombatants. If McMahan can show why unjust combatants are liable and unjust noncombatants are not, then the main claim of the dilemma will be undermined.

\footnotetext{
${ }^{189}$ Lazar, 'The Responsibility Dilemma for Killing in War', p. 204.

${ }^{190}$ McMahan, Killing in War, p. 198.

${ }^{191}$ Lazar, 'The Responsibility Dilemma for Killing in War', p. 206.

${ }^{192}$ Lazar, 'The Responsibility Dilemma for Killing in War', p. 207.
} 


\subsection{McMahan's Response to the Dilemma}

McMahan has recently responded to Lazar's responsibility dilemma. ${ }^{193}$ His first aim is to show that most unjust combatants are liable whilst most unjust noncombatants are not by elucidating the conditions of liability. McMahan hopes that this clarification will show that the responsibility account can walk the middle ground and avoid the horns of the dilemma. He states that whether and to what a person is liable depends on the functions of the following factors: ${ }^{194}$

1) The expected wrongful harm that will occur unless the person is harmed

2) The degree of the person's causal contribution to the harm

3) Whether the harm is foreseeable, and if so, whether the person contributes to its occurrence intentionally, recklessly or negligently

4) If the person meets the necessary conditions of responsibility for the harm

5) Whether there are others who are more responsible for the harm and if so by how much

6) The extent to which the expected harm can be expected to be reduced by harming the person. (In the case of defensive harming, the extent to which successful defence will be effective in reducing the harm depends on the degree of the person's causal contribution to it.)

Below I outline problems with four out of the six conditions; in particular, I try to show why these conditions are not helpful when determining liability to attack. If they are not able to determine liability to attack simpliciter, they are also not going to be helpful in distinguishing between the liability to attack of combatants and noncombatants. I do not raise a problem with the fourth and fifth conditions, which pertain to responsibility. This is because I am arguing in support of the dilemma, which rests on combatants and noncombatants often having similar levels of responsibility for the unjust threat. Indeed, I am relying on the fourth condition, as I think they both have responsibility for the harm. In addition, because I am arguing that combatants and noncombatants have similar levels of responsibility for harm, the fifth condition does not apply.

\footnotetext{
${ }^{193}$ McMahan, 'Who is Morally Liable to be Killed in War'.

${ }^{194}$ McMahan, 'Who is Morally Liable to be Killed in War', p. 548
} 
A problem with the first factor is that it can be difficult to actually identify where the wrongful harm will occur. In 'Responsibility, Risk, and Killing in Self-Defense' Lazar draws on Michael Otsuka's example of a Guest who, when going to shake Dignitary's hand, has a hologram of a gun projected onto his hand. ${ }^{195}$ Dignitary is used to threats upon her life and, acting upon the reasonable belief that Guest is going to kill her, draws her pistol in order to shoot Guest in self-defence. ${ }^{196}$ Lazar uses this case to show that two agent-responsible persons can both be blamelessly responsible for a forced-choice situation arising. ${ }^{197}$ This is relevant because it highlights the difficulty of actually identifying the wrongful harm that needs to be prevented. If both parties are agentresponsible for a forced-choice situation arising (where harm needs to be distributed) then it is not clear where the wrongful harm will fall. This is because it is not clear who will be wronged as each party is responsible for imposing "the risk of suffering an unjustified harm."198

A problem with the second factor has already been discussed above in Section 3.1. The examples of the tradesman and the mafia boss both highlight the difficulties of linking the degree of the causal contribution to liability. At most all that seems to be required is that the attacking agent does make some causal contribution. However it could be the case that the degree of contribution could be relevant in determining how necessary harming that person is. So it could be that the larger a person's causal contribution the more effective, generally, harming them will be in preventing the expected wrongful harm. But if this is what is meant by this factor then it seems to have collapsed into simply another way of stipulating the first and the sixth factor. So all that should be required is that a person causally contributed to the harm, and the thus the degree of their contribution may be ignored as no conclusions can be drawn from that independent of the other factors.

A problem with the third factor is that its scope is too wide. This is evident when we consider it in tandem with McMahan's claim that one does not have to pose the threat oneself in order to be responsible for it. All that is required is a voluntary causal

\footnotetext{
${ }^{195}$ Seth Lazar, 'Responsibility, Risk, and Killing in Self-Defense', Ethics, Vol. 119, No. 4, 2009, pp. 699728.

${ }^{196}$ Michael Otsuka, "Killing the Innocent in Self-Defense" Philosophy \& Public Affairs, Vol. 23, No. 1, 1994, pp. 79-94, at p. 91.

${ }^{197}$ Lazar, 'Responsibility, Risk, and Killing in Self-Defense', pp. 724-5.

${ }^{198}$ Lazar, 'Responsibility, Risk, and Killing in Self-Defense', p. 724.
} 
contribution. Lazar gives the example of A, who has been sacked from his job and blames his boss B. ${ }^{199}$ In order to take revenge he buys a gun from gunsmith C. C is unaware of his intentions and sells the gun to A, who then proceeds, with responsibility, to attack B. The problem with the foreseeability factor is that it entails that $\mathrm{C}$ is agentresponsible, and therefore has some liability, for the attack on B because $\mathrm{C}$ voluntarily facilitated the threat. This is because $\mathrm{C}$, like the conscientious driver with regards to driving in Chapter Two, knows that selling guns is a risky business and that harm may come from it. This means that if killing $\mathrm{C}$ was the only way for $\mathrm{B}$ to fend off the attack then it would be permissible for B to do so because the agent-responsibility of $\mathrm{C}$ renders $\mathrm{C}$ liable. The reason this scope of foreseeability is too wide is that it is foreseeable that virtually any good will be able to be used to harm someone. In particular I foresee this implicating virtually any merchant. Water can be used to drown someone, a broomhandle can be sharpened and used to stab somebody, and, if the movies are to be believed, it is even possible to kill someone with a carrot. ${ }^{200}$ It is extremely counterintuitive that the vendor be liable to defensive attack when one of their goods is used impermissibly. If it is deemed permissible for a product to be sold, then the vendor should prima facie not be responsible for harm threatened with that product. Because McMahan's foreseeability factor has that result, it should be discounted.

A problem with the sixth factor is that it is simply wrong to say that the extent to which defence will be successful depends on the degree of person's causal contribution to it. That is going to depend on the nature of the unjust attack. If it is possible to make an unjust attack hit someone else (perhaps by using them as a shield) then the extent of that person's causal contribution is entirely immaterial. Despite their different causal contributions the tradesman, the mafia boss, and the gunsmith are all equally able to stop a bullet with their bodies.

So it seems that the majority of the elements that make up McMahan's account of liability in his response to Lazar have problems when individually considered. This is a problem for McMahan because it seems that these elements fail to accurately capture what is necessary for liability to defensive harm. If they do not serve to help determine

\footnotetext{
${ }^{199}$ Lazar, 'The Responsibility Dilemma for Killing in War', p. 184. Rodin's cutler example, which was discussed in Section 2.4.2, is of a similar structure.

${ }^{200}$ See the Michael Davis film Shoot 'Em Up (2007).
} 
liability to defensive harm generally, then they are not going to be able to help differentiate the liability of unjust combatants from unjust noncombatants.

\subsection{Responses to the Contingent Pacifism Horn}

I will now turn my attention to the rebuttals that McMahan and Strawser make in response to the contingent pacifism horn. McMahan focuses on the actual contributions that combatants make to the threat as well as the conditional willingness of combatants to kill. McMahan considers that these factors make most unjust noncombatants liable to attack. In contrast, Strawser focuses on the epistemic difficulties. In both instances I will argue that their rebuttals fail.

\subsubsection{What unjust combatants do and would do}

McMahan observes that whilst it may be true that many noncombatants do not make a significant causal contribution to threats that their side poses it seems clear that somebody is posing a threat, as many people get killed and wounded in war! McMahan says that even though only some unjust combatants end up killing,

"it is true of almost all of the others that they go armed into a war zone and would kill just combatants rather than allow themselves or their comrades to be killed. That their circumstances do not prompt them to kill is a matter of luck in avoiding a situation in which they must kill or be killed.,201

Further, the fact that unjust combatants are "able and conditionally committed to kill"202 and the fact that the conditions that would lead them to kill are significantly probable they "significantly increase the objective risk" ${ }^{203}$ that they will harm non-liable people. It is the conditional willingness of combatants to kill which subsequently increases the objective risk that combatants pose. This makes most unjust combatants liable to attack.

First, McMahan places a lot of weight on counterfactual conditionals. Not only is this odd for someone who stipulates that "liability depends on what a person does"204, but the conditional he asserts is problematic. As we saw above, McMahan claims that the conditional that unjust combatants would attack if they were in a kill or be killed situation increases the objective risk that innocent people will be killed. This is an

\footnotetext{
${ }^{201}$ McMahan, 'Who is Morally Liable to be Killed in War', p. 548.

${ }^{202}$ McMahan, 'Who is Morally Liable to be Killed in War', p. 548.

${ }^{203}$ McMahan, 'Who is Morally Liable to be Killed in War', p. 549.

${ }^{204}$ McMahan, 'Who is Morally Liable to be Killed in War', p. 547.
} 
empirical claim and unfortunately for McMahan the research does not seem to support him. Lazar cites a study by General S.L.A. Marshall that suggests that only $15-25 \%$ of Allied soldiers in World War II who could have fired their weapons did so. ${ }^{205}$ This indicates that these are soldiers in life or death combat situations who chose not to fire. This is coupled with the claim based on other studies that most soldiers have a "natural aversion to killing". ${ }^{206}$ So it is not immediately clear that "almost all" unjust combatants would actually pose the threat if placed in a situation where they could.

Maybe what McMahan means is that what combatants do (and therefore what they are responsible for) is get into situations where the probability that they will pose a threat is higher. This increased probability is the risk that translates to the threat. We saw in Chapter Two that Rodin argues that the probability of the threatened harm occurring is a necessary condition of lesser evil justifications for harm, and also plays a role in liability justifications. ${ }^{207}$ If we consider a case of a forced game of Russian roulette it is clear that the victim is permitted to use lethal defensive force against the aggressor, even if the probability of death was small. ${ }^{208}$ But it seems like playing Russian roulette is a different kind of probability to entering a combat zone. Russian roulette is more immediate, in the sense that when the trigger is pulled the probability is very real and calculable. In other instances where there is a potential risk of harm it is not permissible to use lethal defensive force. For instance, pedestrians are not permitted to destroy every car that drives past them even though, as the case of the conscientious driver illustrated, there is a risk that the car might careen out of control and threaten them. However this example serves to illustrate that what is relevant about probability and risk in liability justifications is the size of that probability. One of the reasons that it is impermissible to destroy every car that drives past is because the probability of the car actually threatening you is extremely low. It is undeniable that the likelihood of unjust combatants posing a threat is higher than that of unjust noncombatants. However it is not clear that the difference is great enough to justify liability to attack. This is especially the case when we consider, as I do in the next paragraph, McMahan's reliance on luck, and the role luck plays in determining who becomes a combatant.

\footnotetext{
${ }^{205}$ Lazar, 'The Responsibility Dilemma for Killing in War', p. 190-1.

${ }^{206}$ Lazar 'The Responsibility Dilemma for Killing in War'p. 191.

${ }^{207}$ Chap Two. Sec 2.4.4.

${ }^{208}$ Rodin, 'Justifying Harm', p. 105.
} 
Second, the counterfactual responsibility that McMahan is arguing for faces a further problem with its reliance on luck. For, as McMahan admits, it is "a matter of luck" whether particular combatants actually get into situations where they fire their weapons. $^{209}$ This again highlights an inconsistency with McMahan's stipulation that liability depends on what a person does, for McMahan is claiming that unjust combatants are responsible, and therefore liable to attack, for harms that they only avoid posing due to luck. So they are liable for what they do not actually do. Here is an example that shows why this is problematic and that luck does not convey moral responsibility. Suppose there is a conscientious mob boss who likes to do charity work as a balance to some of the more questionable activities he undertakes. On one particular day he has an act of charity that needs doing, as well as an unjustified hit on an innocent rival. The conscientious mob boss cannot decide which of his coerced lackeys should undertake each particular task. As all of his lackeys are equally capable of performing either task he decides that the best way to decide is by lottery - a system of luck. This results in some of the lackeys being selected to carry out the hit, some selected to carry out the charity work and others not selected for any task. McMahan would be committed to saying that the only reason that the lackeys not carrying out the hit did not, was because they were lucky in not being selected. If McMahan is to be consistent he should say that those not carrying out the hit are still liable to defensive harm, even if they are doing charity work, because "they are conditionally committed to kill.,"210

The conscientious mob boss is broadly analogous to states. McMahan admits that states commit many wrongs, noting that protesting them all "would be more than a full-time job." "211 Similarly states pursue "a great many worthy aims" which citizens can be morally justified in contributing to. ${ }^{212}$ So, like the conscientious mob boss, states commit both wrongs and worthy aims and it can be a matter of luck what type of cause a particular citizen ends up contributing to. This is particularly relevant to war time because in a vast majority of wars the citizenry is compelled to fight (even the now paradigmatic just cause of World War II required conscription) in the same way the conscientious mob boss' lackeys are compelled to carry out the hit if selected for that. Similarly it is a matter of luck as to whether a particular person ends up on the frontline

\footnotetext{
${ }^{209}$ McMahan, 'Who is Morally Liable to be Killed in War', p. 548.

${ }^{210}$ McMahan, 'Who is Morally Liable to be Killed in War', p. 548.

${ }^{211}$ McMahan, 'Who is Morally Liable to be Killed in War', p. 550.

${ }^{212}$ McMahan, 'Who is Morally Liable to be Killed in War', p. 550.
} 
or not. This is especially true of conscription where medical conditions (which we have no control over) can prevent or ensure that certain people will fulfil certain roles. ${ }^{213}$ If McMahan is going to be consistent and say that combatants who avoid battle based solely on luck are liable then surely those who have avoided being on the battle field altogether through luck should also be liable. For, just like the combatants who don't engage in combat, if the civilians' luck had gone the other way then they would be posing a threat. Thus McMahan cannot use luck to show that most unjust combatants are liable to attack as this criterion will extend to include unjust noncombatants who are simply lucky not to be combatants. Relying on luck means that McMahan reinforces the dilemma as he opens his theory up to the total war objection.

\subsubsection{Epistemic difficulties}

Strawser focuses on epistemic difficulties as another way to resist the contingent pacifism horn. Chiefly, Strawser claims that the epistemic problems that Lazar raises for the responsibility account are also going to be applicable to other cases of liability justification such as self-defence. ${ }^{214}$ He supposes that you are strolling down the street when a stranger charges at you with a knife, attempting to stab you. ${ }^{215}$ Strawser observes that you do not need to know with certainty the personal history, decision to fight and so forth of the attacker in order to permissibly defend yourself from them whilst walking down street. Strawser admits that not knowing these details means that you are not going to know with certainty whether the stranger is liable to attack, yet the "possibility of mistake does not negate the evidence you have for the stranger's liability". ${ }^{216}$ Rather, the evidence that you do have is going to be relevant for the permissibility of defensive force. So, for instance, you should be able to discern: whether you have done anything to make yourself liable to attack; whether the attacker may have some other justification for attacking you - perhaps a lesser evil justification; and whether the attacker is morally responsible. ${ }^{217}$ Strawser thinks that with this evidence most would think you are justified in determining that the attacker is liable and that it is thereby permissible to defend yourself. The implication here is that if it is possible for the epistemic hurdles to be

\footnotetext{
${ }^{213}$ This example is a personal one. One of my grandfathers was unable to fight in WWII due to a condition with his foot preventing him from marching long distances. Instead he spent the war constructing Bretton gun carriers, thereby contributing to the threat posed in a less direct way.

${ }^{214}$ Bradley Jay Strawser, 'Walking the Tightrope of Just War', Analysis, Vol. 71, No. 3, 2011, pp. 533-544, at p. 535.

${ }^{215}$ Strawser, 'Walking the Tightrope of Just War', p. 535.

${ }^{216}$ Strawser, 'Walking the Tightrope of Just War', p. 535.

${ }^{217}$ Strawser, 'Walking the Tightrope of Just War', p. 536.
} 
overcome in cases of self-defence it will also be possible to overcome those hurdles in cases of war. This is because, for McMahan and Strawser, the difference between individual self-defence and war is one of degree, not kind. The only difference for war is that it must be known that one has a just cause, and whilst this is difficult, Strawser maintains that it is possible. So according to Strawser, because Lazar presumably thinks you can overcome the epistemic barrier in individual self-defence, then you should be able to overcome it in war.

Unfortunately for Strawser and McMahan, I do not think this line of argument helps the responsibility account negotiate the dilemma as much as they would like. The reason for this is because it does not matter what Lazar or others would think about the case of the attacker with the knife. Rather what is important is what the responsibility account says about the attacker with the knife. The permissibility that Strawser alleges Lazar has for self-defence could be based upon another theory, which would not lend support to the responsibility account at all. For instance it could be the case that people think selfdefence in the example Strawser gives is justified because of a Hobbesian account of self-defence. Strawser has not shown that Lazar, and others, would think that the responsibility account allows for permissible defence against the attacked. ${ }^{218}$ And it seems to me that the responsibility account does struggle with Strawser's example. The reason for this, and a large problem for any responsibility based account, is that it is going to be difficult to determine whether someone is actually morally responsible for their actions and not coerced. The coercion point is particularly relevant, for, as Frankfurt notes: "It is generally agreed that a person who has been coerced to do something ... is not morally responsible for having done it." ${ }^{, 219}$ Further, the contingent pacifist objection is not committed, as Strawser seems to think, to the impossibility of determining liability. This should be clear from the title of the objection: the contingency comes from the difficulty, not the impossibility, of adequately and accurately determining liability. And the fact that Strawser admits "there will usually be more uncertainty in war cases than in self-defence cases" lends support to the contingent pacifist who is more opposed to defensive force in war than in cases of self-defence. This increased uncertainty in war

\footnotetext{
${ }^{218}$ For his criticism of agent responsibility, see Lazar, 'Responsibility, Risk, and Killing in Self-Defense'. In his conclusion Lazar suggests that it is a "live possibility" that there are no defensible theories of selfdefense (p. 728).

219 Harry Frankfurt, 'Alternate Possibilities and Moral Responsibility', in Feinberg, Joel and ShaferLandau, Russ (eds) Reason \& Responsibility: Readings in Some Basic Problems of Philosophy (Wadsworth Publishing Company, $10^{\text {th }}$ Edition 1999), pp. 459-465, at p. 460.
} 
extends beyond determining the evidence relating to the attacker. This is because the certainty you have that you are innocent (as the victim) does not apply in war as it is harder to determine whether your side is innocent or not. So it seems that even if it is possible to determine liability in cases of self-defence, this does not transfer smoothly to cases of war. This reinforces the epistemic difficulties of determining liability in war and consequently reinforces the contingent pacifism horn of the dilemma.

\subsection{Responses to the Total War Horn}

My arguments above should serve to show that the contingent pacifism horn of the dilemma is intact. I will now turn to the responses of Strawser and McMahan to the total war horn of the dilemma. McMahan observes that many of the ways in which unjust noncombatants contribute to an unjust war "almost never make an essential causal contribution to the killing of another person in war." ${ }^{220}$ From these observations McMahan makes three distinct claims that support noncombatants' lack of liability that I will outline then reject in turn. Strawser's objections are very similar to McMahan's so I will consider them together.

\subsubsection{Neglible contribution}

The first point McMahan and Strawser make is that many of the actions that noncombatants are responsible for are "indirect" and "foreseeably negligible" which means they do not make a significant causal difference to the prosecution of the war. ${ }^{221}$ This is particularly true for contributions such as voting and protesting, where, McMahan argues, it is doubtful that the morally preferable action - voting or protesting against the war - would make any causal difference. ${ }^{222}$ As we saw above, McMahan identifies the degree of a person's contribution to a harm as relevant to determining their liability. If a person's action makes a negligible causal contribution then it is going to be difficult for McMahan to ascribe any liability to them.

The problem with this claim is that it leads to another counterfactual quandry. A plausible way to measure the causal contribution of your action to the outcome is to imagine what might have happened if you had not performed the action. When thinking

\footnotetext{
${ }^{220}$ McMahan, 'Who is Morally Liable to be Killed in War', p. 549.

${ }^{221}$ Strawser, 'Walking the Tightrope of Just War', p. 540.

${ }^{222}$ McMahan, 'Who is Morally Liable to be Killed in War', p. 550.
} 
about voting it seems clear that an individual's vote makes little to no difference to the outcome. The chant of one individual at a protest is similarly unlikely to influence an outcome. The implication is that if our actions do not make a difference regarding an outcome's occurrence it is difficult to say we are responsible for it. This is because anything we did or did not do made no difference. However this counterfactual test throws up results that reduce liability in other cases too. Think back to the mafia boss hiring hit men. If any particular hit man turned down the contract then another would take it up and the hit would be carried out. This means that for the hit man who does take the job, their action makes no difference to the outcome, for if they had not killed the target, another hit man would have. This is problematic for McMahan because he would want, at the least, to attribute agent-responsibility to the hitman. The test for determining the causal contribution of action that McMahan wants to use to undermine the importance of noncombatants' contributions similarly undermines the contributions of those who are clearly responsible.

Of course there is the sense that the actions of the hit man resulted in him being the person causally responsible for the death of the target. The causal outcome would be different if another hit man had taken the job. This rejoinder highlights the area in which the negligible contribution response misses the point of the responsibility account. It is not how much one contributes to the threat, but the degree to which one is responsible for the threat coming about that is relevant. Remember that the size of contribution and degree of responsibility do not necessarily mirror each other. Focusing on a counterfactual where the size of contribution is easily imagined away misses that point. The examples of the tradesman and the mafia boss in Section 3.1 above served to show that point. This means that Strawser and McMahan cannot use the size of the contribution as a proxy for responsibility and argue that because civilian contributions are negligible that they are then non-responsible and not liable to attack. With this clarified we are back to the original point of the contingent pacifism horn: there will be a range of responsibility among both combatants and noncombatants and the epistemic difficulties of determining this will again be problematic.

\subsubsection{Justified contributions}

For his second response to the total war horn McMahan argues that many of the contributions, such as taxes or personal wealth, to the economic strength of a state are not 
only compelled or unavoidable but are also morally justified. ${ }^{223}$ This is because of the welfare for the vulnerable, essential infrastructure, and worthy goods that are enabled as a result of these. For McMahan, moral justification for a particular act exempts liability on the basis of that act. This means that performing these morally justified acts will not result in liability.

I dispute the claim that they are morally justified. The main reason for this is because many of the contributions support the wrongs of a state, which as McMahan mentions, would require more than a full time job to protest. Just because some of the contributions go towards worthy aims does not necessarily make them justified. The example of the conscientious mob boss should serve again to illustrate this point. Further, imagine that the mob boss funds his affairs through running a protection racket - the money he uses is compelled. The fact that some of the money goes to worthy projects does not on its own justify the money which also goes to other not so worthy, criminal projects. When the money is taken there is no way to determine what in particular it is going to contribute towards, which means that it is best understood as funding the activities as a whole. It could be the case that an all things considered judgement would take into account the good actions and the bad actions undertaken by the conscientious mob boss and determine that the good outweighs the bad, thereby justifying the contributions. Whilst these calculations are going to be different for every state, it is going to be the case that unjust states will struggle to satisfy all things considered judgements, given they are engaging in unjust activities. Even if we assume that the only wrongs states engage in are wars and that similar contributions in the past only went to good projects this would not change the egregious wrong that the state is currently engaged in and that unjust noncombatants' contributions are currently supporting. Considering the wrongs that a state commits highlights the extra work to be done by McMahan to show that the contributions of citizens are morally justified, thereby excusing them of liability. I am sceptical that such work can be done, especially for warring states.

\subsubsection{Ineffectiveness}

A key point that both McMahan and Strawser make in response to Lazar is that of the ineffectiveness of targeting unjust noncombatants. ${ }^{224}$ This derives from the

\footnotetext{
${ }^{223}$ McMahan, 'Who is Morally Liable to be Killed in War', p. 550.

${ }^{224}$ McMahan, 'Who is Morally Liable to be Killed in War', pp. 550-1; Strawser, 'Walking the Tightrope of Just War', p. 538-9.
} 
aforementioned claim that individual civilians do not make more than a negligible causal contribution. I will rebut this claim in the next chapter in Section 4.4.3.

\subsection{Conclusion}

In this chapter I have defended Lazar's Responsibility Dilemma from the rebuttal of McMahan and Strawser. After outlining the dilemma I argued that the additional categories McMahan introduced did not help to determine liability. I then argued that McMahan's reliance on luck prevented him from escaping the contingent pacifism horn. Similarly Strawser's claim that the epistemic difficulties were easily overcome did not address the problems that the responsibility account faced. I also rebutted Strawser and McMahan's arguments that the negligible and justified contributions of unjust noncombatants affected their liability. My rebuttals mean that the responsibility dilemma continues to pose a problem for McMahan's responsibility account. 


\section{Collective Responsibility and Liability to Attack}

So far the discussion has followed McMahan's focus on individuals and their duties and obligations during a war. In particular I have focused on when and under what circumstances an individual is liable to be harmed. In this chapter I am going to change focus and address a challenge articulated by Noam Zohar. In several papers Zohar questions the individualist perspective assumed by McMahan. ${ }^{225}$ In particular Zohar argues against McMahan (and Judith Jarvis Thomson) in favour of a collectivist perspective and in support of the moral equality of combatants. I am going to depart from Zohar here, by granting McMahan that the moral equality of combatants is false. I am going to argue that war is a collective threat, and therefore requires a collectivist approach. I will show that this collectivist approach, when combined with a more thorough understanding of responsibility, supports the principle that unjust noncombatants can be liable to attack by just combatants. The first section of this chapter will therefore address the nature of the threat posed in war, and argue that it is a collective threat. The second section of this chapter will introduce Tony Honoré's idea of outcome responsibility and show how this accommodates McMahan's example of the conscientious driver. The third section will draw on work by Toni Erskine and others to show that collective responsibility is plausible and that outcome responsibility is compatible with it. The final section will show that this entails the liability of unjust noncombatants by addressing the problems of how to attribute and avoid outcome responsibility.

\footnotetext{
${ }^{225}$ Noam J. Zohar, 'Collective War and Individualistic Ethics: Against the Conscription of 'Self-Defense', Political Theory, Vol. 21, No. 4, 1993, pp. 606-622; Noam J. Zohar, 'Innocence and Complex Threats: Upholding the War Ethic and Condemnation of Terrorism', Ethics, Vol. 114, No. 4, 2004, pp. 734-751; Noam J. Zohar, 'Double Effect and Double Intention: A Collectivist Perspective', Israeli Law Review, Vol. 40, No. 3, 2007, pp. 730-742. Christopher Kutz makes a similar point in Christopher Kutz, 'The Difference Uniforms Make: Collective Violence in Criminal Law and War', Philosophy \& Public Affairs, Vol. 22, No. 2, 2005, pp. 148-180.
} 


\subsection{The Collective Nature of the War Time Threat}

In 'War as Self Defense' McMahan argues in favour of the reductive strategy, which "claims that national defence is reducible to the defence of individuals." ${ }^{226}$ The reductive strategy can either be interpreted to mean that national defence is either the aggregate of many individuals simultaneously exercising their right of self-defence or the state exercising that right on behalf of individuals. ${ }^{227}$ In Killing in War, McMahan has developed this view, claiming that "just warfare is much more than the mere exercise of rights of individual self-defence by just combatants." 228 Rather, just warfare has to incorporate the just cause for war, which is not necessarily a right of self-defence. So the reductive strategy suggests that what is wrong about war is that it violates the rights of individuals.

The problem I have with this approach is McMahan appears to be only referring to the relationship between rights violation and just warfare, not the nature of the threat. We want a proper analysis of the nature of the threat (as opposed to the justification for defence), as it is responsibility for an unjust threat that forms McMahan's criterion for attack in war. McMahan's focus on individual responsibility seems to suggest that he views the threats posed in war as similar to aggregated rights violations; that is a threat in war just is when enough individuals work together in a group to threaten another group of individuals. This is supported in an early paper where he says: "War is a morally special condition only in that the number of people that it causes to render themselves non-innocent vis-a-vis one another is abnormally large." 229 As such, according to McMahan, determining the responsibility of individuals in war will be as simple as determining the contributions of each individual to the threat.

This is not going to be sufficient in explaining the wartime threat. It is too simplistic to reduce the actions of a state going to war as simply the aggregate actions of individuals. ${ }^{230}$ There are two main reasons for this. First, and most importantly, the

\footnotetext{
${ }^{226}$ Jeff McMahan, 'War as Self-Defense', Ethics \& International Affairs, Vol. 18, No. 1, 2004, pp. 75-80, at p. 75.

${ }^{227}$ McMahan, 'War as Self-Defense', p. 75.

${ }^{228}$ McMahan, Killing in War, p. 196.

${ }^{229}$ McMahan, 'Innocence, Self-Defense and Killing in War', p. 195.

${ }^{230} \mathrm{I}$ 'm using the term 'state' because states are a prime example of an organised group. It is entirely plausible that non-state groups (including terrorist organisations) can meet the same criteria for collective responsibility.
} 
structure of the group in which individuals act allows them to do things that they would have not been able to do by themselves. ${ }^{231}$ Reducing the threat of a state to individual actions misses the point that individuals are only able to act as they do due to the cooperation of others in the state. The second reason is that when individuals act in a way that contributes to the threat posed to another state it is very rare that they will be acting on their own volition and representing themselves. Rather, we understand soldiers as acting as representatives of the state. Indeed, soldiers in this sense are the sources of the vicarious action of the state. ${ }^{232}$ It is true that basic actions (such as shooting a gun) can only be performed by individuals. However when we have specific relationships (such as representation or designation) among a group, then it makes sense to say that the basic actions are being performed by a subgroup (e.g. the military) on behalf of the larger group. ${ }^{233}$ An exception to this would be when the members of the subgroup act in a way that they are not authorised to do by the larger group. So, for instance, if individual members of the military violated the laws of war we would hold the individuals, and not the group, accountable for these actions because violating the laws of war constitute acting beyond the scope of what they were authorised to do. ${ }^{234}$

Larry May sums up the two main concerns when he says: "The interdependent actions of many people facilitate the action that is identified as the action of the state. ${ }^{, 235}$ These two points: a) that individual action in war is only possible due to the structure of the group in which they act, and b) that when individuals act in war they often act on behalf of the group and not on their own volition, highlight the problems of thinking about war as a threat that is reducible to the actions of individuals. Whilst it is true that individuals carry out a war, it is misleading to think of any particular combatant as merely an individual agent. ${ }^{236}$ We can only fully understand the actions of a combatant in war as an action on behalf of a group and, as Zohar says: "It is only as part of that effort that his action can (if at all) be justified in the first place". ${ }^{237}$ So to adequately understand the nature of the

\footnotetext{
${ }^{231}$ Larry May, Crimes Against Humanity (Cambridge University Press, 2005), p. 144.

${ }^{232}$ For an account of vicarious agency, see Larry May, The Morality of Groups: Collective Responsibility, Group-Based Harm, and Corporate Rights (Notre Dame: University of Notre Dame Press, 1987), pp. 41-8. ${ }^{233}$ May, The Morality of Groups, p. 33.

${ }^{234}$ If soldiers committed war crimes as a result of following orders then the group would be responsible for what they had directed the soldiers to do. For more on this in relation to the rules of war, see Larry May, War Crimes and Just War (Cambridge University Press, 2007), pp. 35-40

${ }^{235}$ May, Crimes Against Humanity, p. 144.

${ }^{236}$ Zohar, 'Double Effect and Double Intention', p. 737.

${ }^{237}$ Zohar, 'Double Effect and Double Intention', p. 737.
} 
threat in war we have to understand it as a threat posed by a collective, wherein individuals act on behalf of the collective. The group is the agent of the threat. The collective nature of the wartime threat means that an adequate understanding of the threat is going to involve an account of collective responsibility, as it is responsibility for the threat that McMahan is interested in. In the following section I will outline how McMahan's conception of moral responsibility is in fact very similar to what Honoré has called 'outcome responsibility' which I will then link to collective responsibility.

\subsection{Outcome Responsibility and McMahan}

McMahan's analysis criterion of liability to attack relies heavily on the concept of moral responsibility. McMahan thinks that moral responsibility for an objectively unjustified threat is necessary for liability, while guilt and culpability are not. ${ }^{238}$ This is interesting as it is common to understand moral responsibility for an action as containing both causal responsibility and blameworthiness. ${ }^{239}$ As McMahan appears to disassociate moral responsibility from culpability, his account warrants a close examination. In this section I am going to show how McMahan's account of moral responsibility aligns closely with Honoré's account of outcome responsibility. Outcome responsibility is the attribution of the consequences of an agent's actions to an agent in such a way that, other things being equal, the burdens and benefits of that action should fall to them. ${ }^{240}$ It is a narrower notion than causal responsibility, as it does not include being responsible for things that "arise in bizarre and unpredictable ways" such as causing a rock fall by tossing an orange pip over a cliff. ${ }^{241}$ It is also a wider notion than moral responsibility, as it ascribes moral responsibility without ascribing blame or culpability. McMahan's example of the conscientious driver shows how outocome responsibility is the proper basis for liability to defensive harm. I will first set out McMahan's analysis of his example, and then show how it aligns with outcome responsibility.

I first introduced conscientious driver in Chapter Two but I will reproduce it again here:

\footnotetext{
${ }^{238}$ McMahan, Killing in War, pp. 35, 159-63.

239 Marion Smiley, 'From Moral Agency to Collective Wrongs: Re-thinking Collective Moral Responsibility', Journal of Law and Policy, Vol. 19, Iss. 1, 2010, pp. 171-202, at p. 173

${ }^{240}$ David Miller, 'Holding Nations Responsible', Ethics, Vol. 114, No. 2, 2004, pp. 240-268, at p. 245.

${ }^{241}$ Miller, 'Holding Nations Responsible', p. 245.
} 
"A person who always keeps her car well maintained and always drives carefully and alertly decides to drive to the cinema. On the way, a freak event that she could not have anticipated occurs that causes her car to veer out of control in the direction of a pedestrian." 242

McMahan says that from an objective perspective the driver is acting impermissibly. This is because if you act in such a way that you will lose control of the car and it will threaten an innocent person then that is impermissible. ${ }^{243}$ However from a subjective perspective it is permissible because the driver does not, and can not, know that those are the conditions under which she is driving. This is relevant because the different accounts of permissibility render different results when categorising the type of threat that she is. The objective account classifies her as an Excused Threat, whereas the subjective account classifies her as an Innocent Threat. This difference reflects the fact that she is "acting on the basis of epistemically justified but false beliefs." ${ }^{244}$ McMahan notes that the driver does not intend to harm the pedestrian, nor is it foreseeable that she will harm anyone. McMahan also argues that though the act is subjectively permissible, it is not subjectively justified. This is because she has no positive moral reason to take part in the activity. ${ }^{245}$ This is in contrast to an ambulance driver who is driving conscientiously to an accident site yet suffers a similar freak accident. According to McMahan because the ambulance driver is driving to save a person she has a positive moral reason to undertake the activity, hence it is subjectively justified as well as subjectively permissible.

The issue with the conscientious driver is that "she knows that driving is an activity that has a very tiny risk of causing great harm". ${ }^{246}$ This risk is so small that the type of activity is permissible. But unfortunately she has bad luck which means that the risk that "she knowingly imposed ... for the sake of her own interests" has come to pass. ${ }^{247}$ This leads McMahan to conclude that "she is morally liable to defensive action to prevent her from killing an innocent bystander." ${ }^{248}$ McMahan thinks the same result applies in the ambulance driver case too.

\footnotetext{
${ }^{242}$ McMahan, Killing in War, p. 165.

${ }^{243}$ McMahan, Killing in War, p. 165.

${ }^{244}$ McMahan, Killing in War, p. 166.

${ }^{245}$ McMahan ignores the fact that positive utility might arise from travelling to the cinema.

${ }^{246}$ McMahan, Killing in War, p. 165.

${ }^{247}$ McMahan, Killing in War, p. 166.

${ }^{248}$ McMahan, Killing in War, p. 166.
} 
The important point for McMahan is that to be responsible a person must engage "in some form of voluntary action that had some reasonably foreseeable risk of creating a wrongful threat." 249 An agent can only be liable to what happens as a result of our action; we cannot become liable through mere luck. If two people act the same but have different results we might say that this difference comes down to luck, but it is not mere luck. McMahan characterises this as moral luck, a luck that comes into play as the result of our actions and that is reasonably foreseeable. ${ }^{250}$ Because the conscientious driver is responsible for action that imposed the foreseeable risk of inflicting harm on others, it is fair that the driver and not the innocent pedestrian should suffer the costs of the harm. The driver and not the pedestrian is responsible for bringing about the costs. Unfortunately, in this case, the nature of the harm means that it cannot be divided between the two agents. The responsibility that the driver has for the harm means that she should bear the costs. There is an asymmetry between the two in respect to responsibility. ${ }^{251}$ If the harm was divisible then the slightness of the asymmetry might mean that it is not fair to impose all of the costs on one of the parties. However because there is a forced choice in the conscientious driver case somebody has to bear all the costs and it fair for the person responsible for the threat of harm to bear that cost.

It is this inclusion of luck that highlights the closesness of outcome responsibility to McMahan's analysis of the conscientious driver. This idea of luck is integral to outcome responsibility and is an important aspect in justifying appropriate outcomes for our actions. Outcome responsibility recognises that luck plays an essential part in determining how our actions 'play out' in the world. Honoré thinks that if we are to use a system of luck to justify outcome allocation it must be fair. Part of the reason the system is fair is that whilst it entails that "we bear the risk of bad luck we also benefit if our luck is good." ${ }^{, 252}$ So in the case of the conscientious driver she ordinarily benefits from her good luck by attending the cinema, or whatever other action her driving is for. Honoré argues that we implicitly bet on outcomes during everyday life, and frequently take risks for which we claim the benefit or the cost: ${ }^{253}$ "To choose and execute a course of conduct is to bet on your skill and judgement of the probabilities. Choosing is inescapably

\footnotetext{
${ }^{249}$ McMahan, Killing in War, p. 177.

${ }^{250}$ McMahan, Killing in War, p. 177.

${ }^{251}$ Compared to the symmetry that they have with respect to their guilt or culpability.

${ }^{252}$ Honoré, 'Responsibility and Luck', p. 24.

${ }^{253}$ Honoré, 'Responsibility and Luck', pp. 25-6.
} 
betting." 254 This applies to both action and inaction. ${ }^{255}$ Honoré also argues that such a system is also fair because it is, over time, beneficial. The potential benefits will usually outweigh the potential costs. Mere ignorance is not sufficient to absolve responsibility. Honoré suggests that it might be sufficient in absolving blameworthiness and thereby punishment, but not outcome responsibility and a subsequent obligation to recompense for harm. ${ }^{256}$

Outcome responsibility seems to be the kind of responsibility McMahan has in mind when he discusses the responsibility of the conscientious driver. He does not want to attribute blame to the driver, yet he still holds her liable to bear the costs of her risky action. Outcome responsibility explains how she can be responsible for the harm caused in such a way that the cost is hers to bear, without being at fault. This shows that, for McMahan, outcome responsibility is sufficient to ground liability for defensive harm. Because McMahan does not think that the morality pertaining to war is different to that pertaining to ordinary self-defence, if outcome responsibility is sufficient to ground liability in ordinary self-defence it will also be sufficient to ground liability in cases of war. This means that outcome responsibility is the relevant sense of responsibility to be using when determining whether civilians can be liable to attack.

\subsection{Collective Responsibility}

Now I want to turn to the question of whether it is appropriate to apply the notion of collective responsibility to groups and thereby determine whether individuals can be outcome responsible for the actions of the collective.

Erskine argues convincingly that states are moral agents and are thereby legitimate loci of responsibility. ${ }^{257}$ This is controversial; many individualists maintain that persons are the basic unit of ethical reasoning and responsibility. ${ }^{258}$ Erskine disagrees with this. She

\footnotetext{
${ }^{254}$ Honoré, 'Responsibility and Luck', p. 26.

${ }^{255}$ For Honoré's law-focused take on the difference between acts and omissions, see Tony Honoré 'Are Omissions less Culpable?', in Responsibility and Fault (Hart Publishing, 1999), pp. 41-66.

${ }^{256}$ Tony Honoré, 'Being Responsible and Being a Victim of Circumstance', in Responsibility and Fault (Hart Publishing, 1999); Miller, 'Holding Nations Responsible', p. 246.

${ }^{257}$ Toni Erskine, 'Assigning Responsibilities to Institutional Moral Agents: The Case of States and QuasiStates', Ethics \& International Affairs, Vol. 15, No. 2, 2001, pp. 67-85.

${ }^{258}$ See, for example, Jan Narveson, 'Collective Rights?', Canadian Journal of Law and Jurisprudence, Vol. IV, No. 2, 1991, pp. 329-345.
} 
thinks that some institutions and states do possess relevant capacities that render it coherent to assign responsibility to them. ${ }^{259}$ In particular she identifies the capacities of moral deliberation and moral action as fundamental to responsibility. In determining whether these capacities apply to international actors she draws on the Peter French's distinction between "aggregate collectivity" and "conglomerate collectivity". ${ }^{260}$ An aggregate collectivity is a group that is simply a collection of people. A change in the membership necessarily results in a change in identity of the group. This is in contrast with a conglomerate collectivity which is more than simply the "sum of its constituents." ${ }^{261}$ The identity of a conglomerate collectivity is therefore independent of its membership at any particular time. Examples include political parties, sports clubs, corporations, transnational organisations and so on. ${ }^{262}$ A further characteristic of a conglomerate collectivity is that it has "internal organizations and/or decision procedures." 263 This is particularly pertinent to Erskine as it requires that the collective be able to deliberate and to display "a degree of decision-making unity that would allow the collectivity in question to arrive at a predetermined goal". ${ }^{264}$ The criterion of a decision-making function thereby means a collectivity is capable of purposive and coordinated action. French also stipulates that a conglomerate collectivity has an identity over time, which eliminates spontaneous groups. ${ }^{265}$ Erskine also adds that for groups to be candidates for moral agency they must be self-asserting, by which she means they are not externally defined. ${ }^{266}$

These features enable Erskine to establish criteria to determine which types of groups count as moral agents. The criteria that she identifies are: "an identity that is more than the sum of the identities of its constitutive parts; ... a decision making structure; an identity over time; and a conception of itself as a unit." ${ }^{267}$ Groups that have these features are identified as "institutional moral agents" because they possess the capacities of moral

\footnotetext{
${ }^{259}$ Erskine, 'Assigning Responsibilities to Institutional Moral Agents', p. 69.

${ }^{260}$ Peter French, Collective and Corporate Responsibility (New York: Columbia University Press, 1984), Ch. 1.

${ }^{261}$ Erskine, 'Assigning Responsibilities to Institutional Moral Agents', p. 71.

${ }^{262}$ French, Collective and Corporate Responsibility, p. 13.

${ }^{263}$ French, Collective and Corporate Responsibility, p. 13.

${ }^{264}$ Erskine, 'Assigning Responsibilities to Institutional Moral Agents', p. 71.

${ }^{265}$ Erskine, 'Assigning Responsibilities to Institutional Moral Agents', p. 71.

${ }^{266}$ Erskine, 'Assigning Responsibilities to Institutional Moral Agents', p. 72.

${ }^{267}$ Erskine, ‘Assigning Responsibilities to Institutional Moral Agents', p. 72.
} 
deliberation and moral action in ways that are analogous, but not identical, to individual humans. ${ }^{268}$

These criteria are met by states. First, the identity of a state is distinct from the sum of its components. Many of the actions of a state are only able to be described as actions by the state. That is in a way in which is not reducible to descriptions of the actions of its members. Examples of these include, signing international treaties, passing legislation, and, I argue, waging war. Additionally the membership of a state is in a constant state of flux with citizens frequently immigrating, emigrating, being born, and dying. These changes do not ordinarily affect the identity of a state. ${ }^{269}$ Similarly, the government of a state is often prone to change, yet we do not view the change of the individuals in charge as constituting a change in the state. Quentin Skinner states this clearly when he defines the modern state as "an apparatus of power whose existence remains independent of those who may happen to have control of it at any given time." ${ }^{270}$ With relation to the second criterion, the state is capable of deliberating and arriving at a course of action. Erskine claims that the state's capacity for reasoning is in fact "akin to that of a human individual." 271 This is not to claim that states are perfectly rational actors, but rather to emphasise that states are capable of purposive action despite the compromise and questionable reasoning that often pervades politics. Individual humans are similarly capable of purposive action despite epistemological limitations and personal tensions between conflicting values and interests. ${ }^{272}$ Satisfaction of the third criterion is straightforward; states clearly have an identity over time. They recognise past actions and plan for the future. Finally, states also satisfy the fourth criterion of being self-aware. This is perhaps most evident in the constitutions by which states define themselves. The satisfaction of the four criteria lead Erskine to say that it is possible for states to be institutional moral agents and thereby bearers of responsibility. ${ }^{273}$

\footnotetext{
${ }^{268}$ Erskine, 'Assigning Responsibilities to Institutional Moral Agents', pp, 70, 72.

269 'Ordinarily' because an extreme instance of one of these might result in a change to the identity of a state. For instance if all the citizens of a state died then this might cause the state to cease existing.

${ }^{270}$ Quentin Skinner, in Erskine, 'Assigning Responsibilities to Institutional Moral Agents', p. 74.

${ }^{271}$ Erskine, 'Assigning Responsibilities to Institutional Moral Agents', p. 75.

${ }^{272}$ Erskine, 'Assigning Responsibilities to Institutional Moral Agents', p. 75.

273 A further condition of independence and freedom to act are also required for moral agency to be realised. Many states satisfy these too. For Erskine's discussion of the quasi-state, see Erskine, 'Assigning Responsibilities to Institutional Moral Agents', pp. 76-83.
} 
Several points need to be mentioned here. First, I do not want to suggest that Erskine's approach is the only way of determining collective responsibility. Other approaches such as Marion Smiley's and John Parrish's are also promising. Smiley argues for a different conception of agency when determining the responsibility of collectives, ${ }^{274}$ and Parrish argues for an 'authorized state' model where the state is an agent of its citizens. ${ }^{275}$ However I do think that Erskine's view is plausible and shows one way of understanding collective responsibility at the state level. I have chosen it here as I think it aligns closely with outcome responsibility. Second, I am not committed to the idea that states are the only collective group able to have responsibility. I take no position on whether mobs have collective responsibility. It is interesting enough for my purposes that states do, as they are typically the collectives that wage war. It is probable that a similar analysis will satisfy many of the conditions required for responsibility when applied to substate groups waging war against states. Third, Erskine's analysis establishes that states as institutional moral agents can be morally responsible. This goes further than I require as I only need to establish outcome responsibility. However as noted above, because outcome responsibility is necessary for moral responsibility Erskine's account also provides me with outcome responsibility for states. Erskine's capacity based account of institutional moral agency aligns closely with Honoré's capacity based account of outcome responsibility. Indeed, Honoré sees no reason why groups such as states cannot be outcome responsible as they are perfectly capable of exposing themselves to risk. ${ }^{276}$

\subsubsection{The distribution of collective responsibility to individuals}

Assuming that I have established that states can be responsible for their actions, a key issue is whether, if at all, that responsibility is distributed to individuals. I mentioned above that Erskine argues that some duties and responsibilities are only able to be borne by states; that is they are not able to be distributed to individuals. ${ }^{277}$ An example of this is the duty not to wage a war of aggression. This is a duty that an individual is unable to violate, in part because an individual cannot wage a war (nor, as I argued above, can the simple aggregate of individuals actions amount to war). If Erskine is correct, then this leaves us with a problem. If responsibility is unable to be distributed past the state then it is unclear how we should understand the moral status of the citizens of that state. If they

\footnotetext{
${ }^{274}$ Smiley, 'From Moral Agency to Collective Wrongs: Re-thinking Collective Moral Responsibility'.

${ }^{275}$ John M. Parrish, 'Collective responsibility and the state', International Theory, Vol. 1., Iss. 1, 2009, pp. 119-154.

${ }^{276}$ Honoré, 'Being Responsible and Being a Victim of Circumstance,' p. 130.

${ }^{277}$ Erskine, 'Assigning Responsibilities to Institutional Moral Agents', p. 73.
} 
are not responsible, who do we hold to account? Recall that our focus is on distributing the costs of harmful action. It is here that the notion of outcome responsibility becomes particularly pertinent. I think Erskine's worry about distributing responsibility is misplaced. Whilst we may not be able to fully distribute the responsibility for the state's actions, we can recognise that individuals have contributed to an action that has led to harm. Because individuals are outcome responsible for their actions it is plausible to distribute the outcome responsibility for the collective act to them, even if we do not or cannot distribute the moral responsibility of the collective act. Of course it might be the case that Erskine is mistaken and that it is possible to distribute moral responsibility for state acts, either to leaders and other individuals who influenced the decision of the state to commit the wrongful action, or perhaps, following Tracey Isaacs' claim that "acts inherit the moral quality of the whole", ${ }^{278}$ more generally to those who made even small contributions. However, simply recognising that individuals are outcome responsible for their collective actions allows us to fairly distribute the costs of collective actions among individuals. The reason that this is fair is because those individuals typically get the benefits of the collective actions. When considering their contributions to the state, citizens typically benefit from state administered social services, security and so on. Outcome responsibility says that people should take responsibility when what they contribute to goes foreseeably wrong and it is foreseeable that states sometimes (if not frequently) wage unjust wars. This leads to the conclusion that individuals can be outcome responsible for the harm posed when their state goes to war.

\subsection{Objections to Individuals being Outcome Responsible for Collective Action}

There are several objections that I can foresee arising in regard to this claim. Clarifying and responding to these objections will outline some of the circumstances where individuals might not be outcome responsible for the harm posed by their state.

\subsubsection{Responsibility via mere membership}

The first objection is raised by McMahan when he considers whether people can be liable to (or immune from) attack by virtue of their membership in a particular group. ${ }^{279} \mathrm{He}$

\footnotetext{
${ }^{278}$ Tracey Isaacs, Moral Responsibility in Collective Contexts (New York: Oxford University Press, 2011), p. 127.
${ }^{279}$ McMahan, Killing in War, p. 209.
} 
quotes Primo Levi who says: "I do not understand, I cannot tolerate the fact that a man should be judged not for what he is but because of the group to which he happens to belong." 280 McMahan identifies the word 'happens' as crucial here. He argues that sometimes a voluntary choice to become part of a group can ground liability, particularly if the terms of the membership include taking responsibility for the collective actions of the group. ${ }^{281}$ But if the membership of a particular group is involuntary, and this would apply to most citizens of states as citizenship is not something we generally choose, then mere membership is not going to be a basis for liability.

I do not think McMahan's objection is successful against the account I have described above. This is because his argument is consistent with my account. I am not arguing for the conclusion that mere membership is a basis for liability to attack. I am arguing for outcome responsibility as grounding liability. In the context of collective responsibility we are outcome responsible for our acts (and omissions) insofar as they contribute in some relevant way to the outcomes of the collective action. People are not going to be responsible simply because of membership. Young children, for instance, are members of the collective. Yet because they are not in a position to act they are not going to be outcome responsible for the actions of the state. So, McMahan is right that mere membership is not a base for liability, but this does not refute the claim that an outcome responsible act (or omission) as a contribution to collective action is a basis for being liable. The second part to McMahan's objection, the insistence on voluntary membership of the group, is also misguided. The problem with this claim is that it ignores the fact of life that we often find ourselves in situations over which we have no control, and yet are required to act. The fact that we did not voluntarily place ourselves in these situations, that they were handed to us by the fates so to speak, does not diminish our obligations or minimise our responsibility. Consider a case where you are walking with some friends through a forest and come across a child being slowly crushed to death by a fallen tree. The tree is too heavy to be moved by any one person, but together with your friends it would be straightforward to manoeuvre the tree and save the child. It is of course true that you did not voluntarily choose to be in a situation where the life of the child was in the hands of your party. However by chance you are in such a position and it seems clear that the group is outcome responsible for the fate of the child. This would be true even if

\footnotetext{
${ }^{280}$ Primo Levi in McMahan, Killing in War, p. 209.

${ }^{281}$ McMahan, Killing in War, p. 209.
} 
your group would be late for some important event. We often have no control over the circumstances we find ourselves in, yet it seems our duties and obligations to others still apply in these situations. So even though we have no control over the state we are born into, we still have obligations towards others, through collective outcomes that we contribute to. As Miller says: "My responsibilities are thrust upon me by circumstances, but they do not cease to be my responsibilities because of that." ${ }^{282}$ So it is clear that voluntary entry is not required to be responsible for the actions of a group.

\subsubsection{Is it possible to avoid outcome responsibility for collective action?}

The second objection draws on a point made by Narveson. Arguing against irreducible collective responsibility, he claims that in any particular group there are likely to be many individuals who either refrained from the horrific action in question or actively went out of their way to oppose it. As such irreducible collective responsibility will entail "laying blame on someone who is not only innocent, but possibly praiseworthy in the extreme."283 Now the sense of responsibility I am advocating in this chapter is not irreducible, nor does it seek to lay blame or praise. Nevertheless Narveson's point is relevant because it brings to the fore this important question: Is it possible to avoid being outcome responsible for contributions made to collective action? Narveson's challenge forces us to deal with attributing outcome responsibility to those who do not actively support a state's actions and those who vehemently oppose it. I will first look at outcome responsibility for those who do not actively participate then, address what is required to avoid outcome responsibility.

\subsubsection{Attributing outcome responsibility to the inactive and the opposed}

Miller provides a compelling account as to why mere inactivity will not relieve individuals of their group-based responsibility. He refers to Feinberg's discussion of postbellum racism in the American South. ${ }^{284}$ In this environment violent acts against blacks were undertaken in a context where Southern whites were generally passively sympathetic to such acts, even if not undertaking them themselves. There was a shared

\footnotetext{
${ }^{282}$ Miller, 'Holding Nations Responsible', p. 257.

${ }^{283}$ Jan Narveson, 'Collective Responsibility', The Journal of Ethics, Vol. 6, Iss. 2, 2002, pp. 179-198, at p. 190.

${ }^{284}$ Joel Feinberg, Collective Responsibility, The Journal of Philosophy, Vol. 65, No. 21, 1968, pp. 674688 , at p. 686.
} 
culture of racial inequality that led to solidarity among whites, even amongst those who might not have approved of the lynchings. This leads Miller to claim "that where a community of people shares a set of cultural values, one of whose effects is to encourage behaviour that results in outcome $\mathrm{O}$, then everyone who belongs to the community shares in the responsibility for $\mathrm{O}$, even if they disapprove of it." ${ }^{285}$ Participation in the community helps to "sustain the climate of opinion" that leads to the actions in question happening. This seems to apply particularly to the modern United States. There is a culture in the United States of 'American Exceptionalism,' whereby Americans view themselves as a different from other states, and world leaders in democratic progress. Conservative politicians in particular use this rhetoric to justify an expansive and aggressive foreign policy. ${ }^{286}$ Even though many Americans are critical of this kind of foreign policy they can be thought to be responsible for participating in a community where this culture is encouraged. So it seems clear that passive inactivity is not going to enable a person to avoid responsibility for collective actions. Something more is required.

I will now address Narveson's most forceful claim; that there are those who actively oppose the wrongful actions committed by their group. Addressing this claim will help elaborate what is required to avoid collective responsibility. I want to start first by considering the case of the dissenting minority. Miller gives the case of an employeecontrolled company whose processing plant pollutes a river. ${ }^{287}$ The employees discuss whether to introduce a more expensive process to reduce the pollution or to continue with the status quo. Opinion is divided, but the majority favours the status quo and so the factory continues to pollute. Miller claims that the employees are collectively responsible for the damage they cause and if they are required to pay costs to clean up the pollution then all employees should bear those costs. ${ }^{288}$ The reason for this is that the dissenting minority are still outcome responsible for the actions of the collective. They are treated fairly, getting the benefits, such as income, that come with the job and have a fair chance to influence the decisions of the company. As such they must be prepared to "carry their

\footnotetext{
${ }^{285}$ Miller, 'Holding Nations Responsible', p. 252.

${ }^{286}$ See, for example, James Q. Wilson, 'American Exceptionalism', The American Spectator, Vol. 39, Iss. , 2006, pp. 36-43; and Francis P. Sempa, ‘American Exceptionalism’, American Diplomacy, Oct. 19, 2011.

${ }^{287}$ Miller, 'Holding Nations Responsible', p. 253.

${ }^{288}$ Miller, 'Holding Nations Responsible', p. 253.
} 
share of the costs" that result from the company's decisions. ${ }^{289}$ It would not be appropriate to blame or punish them for the pollution, but they are still outcome responsible and therefore liable to bear the costs. Being a member of a dissenting minority and voting against a policy is therefore not a sufficient way to avoid outcome responsibility. (Indeed, a key aspect of democratic theory is that the losing side be bound by the result. ${ }^{290}$ )

This translates easily to states; Anna Stilz for example has argued that citizens of democracies are collectively responsible for the actions of their states. ${ }^{291}$ The key for Miller here though is that the decision making process be fair, and it is here that comparisons with non-democratic states run into trouble. If the company example is changed so that the decision-making is made by a select few who do not inform the other shareholders of their decisions then it would not be appropriate to attribute responsibility for the decision to the general worker as she was not involved in making the decision. Rather collective responsibility would extend only to the decision making group. ${ }^{292}$ When applying this reasoning to states it implies, plausibly, that citizens of states that are not democracies are not going to be responsible for the actions of the state as they have little influence over the decision making of the state. ${ }^{293}$ This is going to be true in some cases but not all. The instance where it is not going to be true is where the decisions of the autocracies reflect the national will. ${ }^{294}$ In these cases the shared national culture will be sufficient to ground responsibility for the action. Examples of states like these might be Middle Eastern monarchies where many social outcomes are supported by large percetages of the population, even though they had no role in the decision making process. These cases are more similar to the postbellum South and show that responsibility for collective action does not depend upon active support for the action.

\footnotetext{
${ }^{289}$ Miller, 'Holding Nations Responsible', p. 253.

${ }^{290}$ The exception here being things that are obviously unjust, or outside the jurisdiction of a parliament.

${ }^{291}$ Anna Stilz, 'Collective Responsibility and the State', The Journal of Political Philosophy, Vol. 19, No. 2, 2011, pp. 190-208. For a response to Stilz, see Endre Begby, 'Collective Responsibility for Unjust Wars', Politics, Vol. 32, No. 2, pp. 100-108.

${ }^{292}$ Miller, 'Holding Nations Responsible' p. 253. I'm going to follow Miller's lead here and leave aside discussion of intermediary cases.

${ }^{293}$ There is a danger here of overstating the influence individual votes have in a democracy. The point is that democracies at least allow for citizens to have some influence, whereas in autocracies there is often no such mechanism.

${ }^{294}$ Miller, 'Holding Nations Responsible', p. 261. The important point here is the extent to which their legitimacy depends upon their support by the people.
} 


\subsubsection{Avoiding collective outcome responsibility}

How then is one to avoid being collectively responsible for a group action? Miller acknowledges that it is difficult to clearly state exactly what is required beyond that a person "must take all reasonable steps to prevent the outcome occurring." 295 The reason this is so imprecise is because what is reasonable is going to depend upon the particulars of each case. An important factor that is going to be variable is the costs that different forms of action will impose on dissenters. Miller has us again consider the case of the postbellum South. If a person joined the National Association for the Advancement of Colored People, took part in anti-racism demonstrations and because of these actions suffered hostility from their neighbours, then Miller thinks they have surely done enough to avoid being responsible. ${ }^{296}$ Similarly if another person started taking part in similar activities but then received serious threats from racist groups as to the safety of their home and family then they should also be exempted from responsibility. ${ }^{297}$ Threats like that are not ones that we reasonably expect an average person to bear. If some do decide to bear those costs then we call them heroic, but as Miller says: "our judgments of responsibility must be based on (admittedly imprecise) judgments about what can reasonably be expected of people in general, not on what exceptional individuals are able to achieve." 298

When determining how individuals are to avoid responsibility for state action two factors seem particularly relevant: coercion (as mentioned above) and propaganda. State coercion can put a high cost on dissent. This is in part helped by states which claim a monopoly on the legitimate use of force, and history demonstrates that they are not afraid to use this force, often against nonviolent protestors. Recent examples of this include Russia, China, Syria, Belarus and Myanmar. On the flipside, many nonviolent protests have been successful; witness the regime changes that marked the end of the Cold War. The challenge for citizens is determining whether dissent is feasible and whether sufficient numbers of people can act together to make the dissent effective. It is difficult to have knowledge of these factors prior to the fact, and then weigh these against the cost of the dissent. The only cases where this is a straightforward calculation is where the cost of dissent is minimal. If states allow free exercise of speech and assembly, as New

\footnotetext{
${ }^{295}$ Miller, 'Holding Nations Responsible', p. 255.

${ }^{296}$ Miller, 'Holding Nations Responsible', p. 255.

${ }^{297}$ Miller, 'Holding Nations Responsible', p. 255.

${ }^{298}$ Miller, 'Holding Nations Responsible', p. 255.
} 
Zealand does, then we should reasonably expect citizens to protest injustices performed by the state. ${ }^{299}$ However if countries do not allow such liberties then it is not so clear that we can reasonably expect citizens to protest. It is apparent that there needs to be a distinction made between democracies and authoritarian regimes, with some states occupying intermediate positions on the scale. In democracies such as New Zealand, ordinary citizens are more likely to be outcome responsible for the actions of their state as we can reasonably expect citizens to dissent due to the minimal costs. In extreme authoritarian states such as North Korea ordinary citizens are most likely never going to be outcome responsible for the actions of the state as protest bears so heavy costs. According to North Korea's official news agency Kim Jong Un's uncle and second in command was recently executed for, among other things, "half-heartedly clapping". ${ }^{300}$ In such an environment resistance is unreasonably risky. ${ }^{301}$

North Korea also provides a good example of the problems of propaganda. Citizens are subject to an intensive propaganda programme, which means that it is difficult to claim that the views of North Koreans are genuine. This is relevant because the state may try to pass responsibility to citizens by claiming that state actions align with popular will. Indeed, the election results of North Korea give near unanimous support for the ruling party. Whilst North Korea is an extreme example, there have been many other personality cults, such as those of Stalin and Hitler, and more conventional regimes where states control news sources and propaganda is widespread. Miller reminds us that "where current political attitudes can be directly traced to sustained propaganda efforts by an autocratic regime that allows no dissenting voices to be heard ... it is much less plausible to hold ordinary people responsible for the consequences that follow." ${ }^{, 32}$ It seems plausible that such a concern can apply to some democratic regimes too. An example of this is the Israeli occupation of Palestinian territories and the justificatory

\footnotetext{
${ }^{299}$ McMahan thinks that jail for conscientious objectors is a reasonable cost to bear in order to avoid harming innocents. They are "severe but ... seldom intolerable." (McMahan, Killing in War, p. 133.) McMahan also argues for a great acceptance of conscientious refusal (McMahan, Killing in War, pp. 95103.)

300 Korean Central News Agency, 'Traitor Jang Song Thaek Executed', December 13, 2013, URL: http://www.northkoreatech.org/2013/12/13/full-text-of-kcna-announcement-on-execution-of-jang/ (Accessed January 29, 2014).

${ }^{301}$ Many North Koreans are not executed but sent to political prison camps that have many similarities to Nazi concentration camps. For a fascinating account of a North Korean who was born in one of these camps and subsequently escaped, see Blaine Harden, Escape from Camp 14: One Man's Remarkable Odyssey from North Korea to Freedom in the West (Viking, 2012) .

${ }^{302}$ Miller, 'Holding Nations Responsible', p. 262.
} 
propaganda put forward by the Israeli state. It seems that such a concern is going to operate on a scale and the freedom of press in Israel is going to counter somewhat the efforts of the state leaving Israeli citizens much more likely to be responsible than North Koreans. In general though it seems that the more open a state is then the lower the costs of dissent will be, as well as the likelihood and effectiveness of propaganda. As such, the more open a state is the more justified we are going to be in holding its members responsible for its decisions and policies. ${ }^{303}$

\subsubsection{The effectiveness of attacking civilians}

A problem for McMahan is that if noncombatants are outcome responsible for the unjust threat of harm their state poses, then this entails that they might be liable to military attack in war. In Section 3.4.3 I noted that Strawser and McMahan both think that noncombatants are generally not going to be liable to attack in war because targeting them would be an ineffective way of pursuing the just cause. I will now rebut this claim.

The reason that Strawser and McMahan give for noncombatants not being liable is because individually they do not make more than a negligible causal contribution to the harm. This means that that "military attacks against civilians generally cannot be an effective means of pursuing a just cause. ${ }^{" 304}$ If it is not an effective means of countering the unjust threat then it should not be pursued. In contrast, targeting unjust combatants is an effective means of countering the unjust threat, which explains why they should be targeted and not noncombatants.

The specific reason that attacking noncombatants is not going to be effective is because "killing them cannot be directly effective as a means of averting a wrongful threat in the way that killing in self-defense is." If you kill someone in self-defence then you are killing the person posing the threat; their death is almost guaranteed to result in the negation of the threat. McMahan does not think that civilians are like this though, for the reason that the contributions they make "to the threats their state poses in war often lie in the past and can no longer be prevented." ${ }^{305}$ So, the contribution they made to the instigation of the war can no longer be prevented. Therefore, McMahan concludes, "the only way that killing civilians can [generally] serve as a means of averting an unjust

\footnotetext{
${ }^{303}$ Miller, 'Holding Nations Responsible', p. 262.

${ }^{304}$ McMahan, Killing in War, p. 225.

${ }^{305}$ McMahan, Killing in War, p. 226.
} 
threat is indirectly, through affecting the action of others". ${ }^{306}$ This would be done by prompting survivors of such attacks to put pressure on the government to end the war for fear that they too will die. The problem with such a strategy is that it is notoriously unreliable. McMahan notes that the use of such tactics by the British and the Germans during World War II had the opposite effect, and in fact strengthened resolve in the face of a hated enemy. ${ }^{307}$

I think that this argument misunderstands the nature of the threat that noncombatants pose. As I have argued, the nature of the threat they pose is a collective threat; something they pose in virtue of the contributions that each individual makes in relation to the contributions of other individuals. It would be impossible to conduct a war without a material contribution from the civilian population. McMahan has misunderstood the relevant ways in which noncombatants continue to make contributions to the war threat. They do not merely contribute to the instigation of the war. Indeed, this is reflected in the way that noncombatants are generally attacked in war. It is very rare in war that any individual civilian is targeted as a result of the direct threat they pose (with an exception being assassination attempts on heads of state). Rather, multiple civilians are targeted at a time because it is together that they constitute a very real threat. This is why we see the targeting of key military infrastructure such as munitions factories or steel works during war time. These institutions and the people working in them contribute to the unjust threat as they provide the material with which the threats are materialised. The nature of a collective threat on the scale of war is not as immediate as a typical case of individual self-defence. This means that an example of an effective response to a collective threat would be bombing an essential munitions factory. It would be effective because it would mitigate the future aggregated threat that comes from production of munitions. Indeed, depending on the situation, targeting noncombatants and noncombatant infrastructure might actually be more effective at negating the unjust threat than killing frontline troops. A situation where this would be the case would be a state that has a large population, and thus easily replaceable frontline troops, but not many essential assets, such as ore mines, that if destroyed would mitigate the threat by shutting down the capacity of the country. This shows how killing unjust noncombatants can be an effective means to avert the

\footnotetext{
${ }^{306}$ McMahan, Killing in War, p. 226.

${ }^{307}$ McMahan, Killing in War, p. 226.
} 
unjust threat in a way that does not rely on making civilians put pressure on their government to end the war.

It is worth recalling that the aim of outcome responsibility is to fairly determine where the costs and benefits of outcomes that we are at least agent-responsible for should fall. Because just combatants are in no way responsible for the harm they face in war, the indivisible cost should fall upon those who are responsible. I have shown above that the effectiveness of attacking unjust noncombatants as a means of averting the threat of war does not depend upon influencing the wills of others. It can also be effective in materially hindering the ability of the unjust state to continue to pose the unjust threat. It should be clarified that this entails that only when it is effective will it be permissible to attack unjust noncombatants (though total slaughter would be an effective but almost certain disproportionate means of negating an unjust threat). Their outcome responsibility for the unjust threat does not necessarily make them liable to blame or punishment. Unjust noncombatants who are only outcome responsible are not liable to be killed wantonly. They are only liable when doing so will be an effective way of negating the threat.

\subsection{Conclusion}

In this chapter I have argued for a collectivist understanding of the threat of war. This led me to develop an account of collective outcome responsibility based on the claim that outcome responsibility is the relevant sense of responsibility for McMahan's account. I then argued for noncombatants being collectively outcome responsible for the harms their state poses. After considering some objections I have concluded that unjust noncombatants can be liable to attack when it is effective to do so. 


\section{Concluding Remarks}

In this thesis I have explored some contemporary issues in jus in bello, focusing on the work of Jeff McMahan. Killing in War has established itself as one of the cornerstone texts on the ethics of war and the arguments it has raised for our understanding the morality of war are central to the debate. As a phenomenon, war shows little sign of disappearing, with recent conflicts in Afghanistan, Syria, Libya, and Sudan. Indeed, as I do my final editing, the news is coming through that the Russian Parliament has authorised their troops to occupy parts of Ukraine. In order to appropriately respond to these events an understanding of the moral permissibility of these conflicts is vital. Each of my chapters deals with a distinct issue relating to the moral permissibility of war and thus, I hope, contributes to the wider debate. In particular, my final chapter's conclusions about the permissibility of intentionally targeting noncombatants has important implications for the way we conduct war as it has the result that far more people are liable to attack than previously though.

The issues raised by McMahan are distinct enough to each warrant particular attention. The structure of my thesis was such that it divided into two halves. The first half focused on McMahan's developments of specific in bello issues; determining who is liable to attack and proportionality. The second half had a contrasting focus. There I looked at implications of McMahan's account of liability to attack; in particular I highlighted concerns raised by Lazar's responsibility dilemma and then looked at how McMahan's understanding of responsibility entailed noncombatant liability when understood collectively.

My first chapter discussed McMahan's account of liability to attack and his criticisms of the traditional view. Benbaji's problem of the sleeping soldiers brought the issue of innocent threats to the fore and I suggested that separate principles governing the permissibility of self-defense when all parties are innocent could run parallel to McMahan's responsibility focused account. Applying McMahan's account to the in bello condition of discrimination highlighted the problems with the moral equality of 
combatants. I also refuted Thomas Hurka's waiver based argument for the moral equality of combatants.

The second chapter traced the recent development of the in bello proportionality requirement. I followed the understanding of proportionality from Sidgwick and Walzer, through Hurka to the innovations of McMahan and Rodin. I argued that McMahan's introduction of narrow and wide proportionality and the factors of intention and liability as relevant to the proportionality condition were innovative, but did not go far enough. Rodin's account introduced significantly more factors as well as a way to understand their relationship. After considering a problem inspired by Hobbes, that of the practical difficulty of determining and weighing multiple factors, I concluded that Rodin's approach was the most comprehensive, and therefore preferred, account of proportionality.

My third chapter defended Lazar's responsibility dilemma from the rebuttals of McMahan and Strawser. I argued that four of the factors McMahan introduced in an attempt to clarify liability had problems. This meant that he was unable to differentiate between combatants and noncombatants with regards to differing levels of responsibility for an unjust threat. I also considered some specific objections to both the contingent pacifism horn and total war horn and found them all wanting.

My final chapter argued that unjust noncombatants can be liable to intentional attack. To establish this I argued for properly understanding war as a collective threat. I also used the example of the conscientious driver to show how McMahan's understanding of moral responsibility aligned closely with Honoré's account of outcome responsibility. After establishing an account of collective responsibility I argued that unjust noncombatants are collectively outcome responsible for the threat their state poses. As such it is often going to be fair that the harm they are outcome responsible for fall on them and not on the innocent just combatants. To establish this last claim I argued for the effectiveness of attacking civilians in certain situations, arguing that their ongoing contribution to the threat means that targeting them can be an effective means of averting the threat.

My last two chapters in particular have been critical of McMahan. Whilst accepting his rejection of the moral equality of soldiers I have argued for a dilemma internal to his 
work. The conclusion that it will often be permissible to intentionally target unjust noncombatants is one that he will presumably not be pleased with. I think this serves to show that the issues McMahan has argued about are far from settled and discussion of the ethics of war has a fruitful future ahead. 


\section{Bibliography}

Anscombe, G. E. M., Ethics, Religion and Politics (Oxford: Oxford University Press, 1981).

Bass, Gary J., 'Jus Post Bellum', Philosophy \& Public Affairs, Vol. 32, No. 4, 2004, pp. $384-412$.

Begby, Endre, 'Collective Responsibility for Unjust Wars', Politics, Vol. 32, No. 2, 2012, pp. 100-108.

Benbaji, Yitzhak, 'Culpable Bystanders, Innocent Threats and the Ethics of SelfDefense', Canadian Journal of Philosophy, Vol. 35, No. 4, 2005, pp. 585-622.

Benbaji, Yitzhak, 'The Responsibility of Soldiers and the Ethics of Killing in War', The Philosophical Quarterly, Vol. 57, No. 229, 2007, pp. 558-572.

Benbaji, Yitzhak, 'A Defense of the Traditional War Convention', Ethics, Vol. 118, No. 3, 2008, pp. 464-495.

Benbaji, Yitzhak, 'The Moral Power of Soldiers to Undertake the Duty of Obedience', Ethics, Vol. 122, No. 1, 2011, pp. 43-73.

Buchanan, Allen, 'Institutionalizing the Just War', Philosophy \& Public Affairs, Vol. 34, No. 1, 2006, pp. 2-38.

Chomsky, Noam, Hegemony or Survival: America's Quest for Global Dominance (New York: Henry Holt and Company, 2003). 
Coady, C. A. J., 'The Status of Combatants', in Rodin, David, and Shue, Henry (eds), Just and Unjust Warriors: The Moral and Legal Status of Soldiers (Oxford: Oxford University Press, 2008), pp. 153-175.

Coates, Anthony, 'Is the Independent Application of jus in bello the Way to Limit War?', in Rodin, David, and Shue, Henry (eds), Just and Unjust Warriors: The Moral and Legal Status of Soldiers (Oxford: Oxford University Press, 2008), pp. 176-192.

Copp, David, 'Hobbes on Artificial Persons and Collective Actions', The Philosophical Review, Vol. 189, No. 4, 1980, pp. 579-606.

Curran, Eleanor, 'Hobbes's Theory of Rights: A Modern Interest View', The Journal of Ethics, Vol. 6, No. 1, 2002, pp. 63-86.

Doggett, Tyler, 'Recent Work on the Ethics of Self-Defense', Philosophy Compass, Vol. 6, No. 4, pp. 220-233.

Downie, R. S., 'Collective Responsibility', Philosophy, Vol. 44, No. 167, 1969, pp. 6669.

Dunn, John, The Political Thought of John Locke (Cambridge: Cambridge University Press, 1969).

Erskine, Toni, 'Assigning Responsibilities to Institutional Moral Agents: The Case of States and Quasi-States', Ethics \& International Affairs, Vol. 15, No. 2, 2001, pp. 67-85.

Fabre, Cécile, 'Guns, Food, and Liability to Attack in War', Ethics, Vol. 120, No. 1, 2009, pp. 36-63.

Fabre, Cécile, 'Internecine War Killings', Utilitas, Vol. 24, Iss. 2, 2012, pp. 214-236.

Feinberg, Joel, 'Collective Responsibility', The Journal of Philosophy, Vol. 65, No. 21, 1968, pp. 674-688. 
Frankfurt, Harry, 'Alternate Possibilities and Moral Responsibility', in Feinberg, Joel and Shafer-Landau, Russ (eds) Reason \& Responsibility: Readings in Some Basic Problems of Philosophy (Wadsworth Publishing Company, $10^{\text {th }}$ Edition 1999), pp. 459-465.

French, Peter, Collective and Corporate Responsibility (New York: Columbia University Press, 1984).

Frowe, Helen, 'Equating Innocent Threats and Bystanders' Journal of Applied Philosophy, Vol. 25, No. 4, 2008, pp. 277-290.

Frowe, Helen, 'Threats, Bystanders and Obstructors', Proceedings of the Aristotelian Society, Vol. 109, No. 3, 2008, pp. 345-351.

Gardner, John, and Tanguay-Renaud, François, 'Desert and Avoidability in SelfDefense', Ethics, Vol. 122, No. 1, 2011, pp. 111-134.

Hobbes, Thomas, Leviathan, Oakeshott, Michael (ed.), (Oxford: Basil Blackwell, 1946).

Honoré, Tony, Responsibility and Fault (Hart Publishing, 1999).

Hurka, Thomas, 'Proportionality in the Morality of War', Philosophy \& Public Affairs, Vol. 33, No. 1, 2005, pp. 34-66.

Hurka, Thomas, 'Liability and Just Cause', Ethics \& International Affairs, Vol. 21, No. 2, 2007, pp. 199-218.

Hurka, Thomas, 'Proportionality and Necessity', in Larry May (ed.), War: Essays in Political Philosophy (Cambridge: Cambridge University Press, 2008), pp. 127-144.

Isaacs, Tracy, Moral Responsibility in Collective Contexts (New York: Oxford University Press, 2011).

Johnson, James Turner, Just War Tradition and the Restraint of War: A Moral and Historical Inquiry, (Princeton: Princeton University Press, 1981). 
Johnson, James Turner, Can Modern War Be Just?, (Yale University Press, 1984).

Kaufman, Whitley, 'Book Review: Jeff McMahan, Killing in War', Ethics, Vol. 120, No. 2, 2010, pp. 399-404.

Kershaw, Ian, The End: Germany 1944-45 (Penguin Books, 2012)

Killoren, David, and Williams, Bekka, 'Group Agency and Overdetermination', Ethical Theory and Moral Practice, Vol. 16, Iss. 2, 2013, pp. 295-307.

Korean Central News Agency, 'Traitor Jang Song Thaek Executed', December 13, 2013, URL: $\quad$ http://www.northkoreatech.org/2013/12/13/full-text-of-kcna-announcement-onexecution-of-jang/ (Accessed January 29, 2014).

Kutz, Christopher, Complicity: Ethics and Law for a Collective Age (Cambridge University Press, 2000).

Kutz, Christopher, 'The Difference Uniforms Make: Collective Violence in Criminal Law and War', Philosophy \& Public Affairs, Vol. 22, No. 2, 2005, pp. 148-180.

Kutz, Christopher, 'Fearful Symmetry', in Rodin, David, and Shue, Henry (eds), Just and Unjust Warriors: The Moral and Legal Status of Soldiers (Oxford: Oxford University Press, 2008), pp. 69-86.

Lackey, Douglas, The Ethics of War and Peace (Englewood Cliffs, N. J.: Prentice-Hall, 1989).

Lang, Gerald, 'Excuses for the Moral Equality of Combatants', Analysis, Vol. 71, No. 3, 2011, pp. 512-523.

Lawson, Brian, 'Individual Complicity in Collective Wrongdoing', Ethical Theory and Moral Practice, Vol. 16, Iss. 2, 2013, pp. 227-243. 
Lazar, Seth, 'Responsibility, Risk, and Killing in Self-Defense', Ethics, Vol. 119, No. 4, 2009, pp. 699-728.

Lazar, Seth, 'The Responsibility Dilemma for Killing in War: A Review Essay', Philosophy \& Public Affairs, Vol. 38, No. 2, 2010, pp. 180-213.

Lazar, Seth, 'Introduction,' Ethics, Vol. 122, No. 1, 2011, pp. 8-9.

Lazar, Seth, 'Necessity in Self-Defense and War', Philosophy \& Public Affairs, Vol. 40, No. 1, 2012, pp. 3-44.

Levinson, Sanford, 'Responsibility for Crimes of War', in Cohen, Marshall, Nagel, Thomas, and Scanlon, Thomas (eds), War and Moral Responsibility (Princeton, Princeton University Press, 1974) pp. 104-133.

Leveringhaus, Alex, 'The Moral Status of Combatants during Military Humanitarian Intervention', Utilitas, Vol. 24, Iss. 2, pp. 237-258.

Lichtenberg, Judith, 'War, Innocence, and the Doctrine of Double Effect', Philosophical Studies, Vol. 74, No. 3, 1994, pp. 347-368.

Lichtenberg, Judith, 'How to Judge Soldiers Whose Cause is Unjust', in Rodin, David, and Shue, Henry (eds), Just and Unjust Warriors: The Moral and Legal Status of Soldiers (Oxford: Oxford University Press, 2008), pp. 112-130.

Long, Graham, 'Disputes in just war theory and meta-theory', European Journal of Political Theory, Vol. 11, No. 2, pp. 209-225.

Mavrodes, George I., 'Conventions and the Morality of War', Philosophy \& Public Affairs, Vol. 4, No. 2, 1975, pp. 117-131.

May, Larry, The Morality of Groups: Collective Responsibility, Group-Based Harm, and Corporate Rights (Notre Dame: University of Notre Dame Press, 1987). 
May, Larry, Crimes Against Humanity (Cambridge University Press, 2005).

May, Larry, 'Killing Naked Soldiers: Distinguishing between Combatants and Noncombatants', Ethics \& International Affairs, Vol. 19, No. 3, 2005, pp. 39-53.

May, Larry, War Crimes and Just War (Cambridge University Press, 2007).

May, Larry, Aggression and Crimes Against Peace (Cambridge University Press, 2008).

McMahan, Jeff, 'Self-Defense and the Problem of the Innocent Attacker', Ethics, Vol. 104, No. 2, 1994, pp. 252-290.

McMahan, Jeff, 'Innocence, Self-Defense and Killing in War', The Journal of Political Philosophy, Vol. 2, No. 3, 1994, pp. 193-221.

McMahan, Jeff, The Ethics of Killing: Problems at the Margins of Life (New York: Oxford University Press, 2002).

McMahan, Jeff, 'The Ethics of Killing in War', Ethics, Vol. 114, No. 4, 2004, pp. 693733.

McMahan, Jeff, 'War as Self-Defense', Ethics \& International Affairs, Vol. 18, No. 1, 2004, pp. 75-80.

McMahan, Jeff, 'Just Cause for War', Ethics \& International Affairs, Vol. 19, No. 3, 2005, pp. 1-21.

McMahan, Jeff, 'The Morality of War and the Law of War', in Rodin, David, and Shue, Henry (eds), Just and Unjust Warriors: The Moral and Legal Status of Soldiers (Oxford: Oxford University Press, 2008), pp. 19-43.

McMahan, Jeff, Killing in War (Oxford: Oxford University Press, 2009). 
McMahan, Jeff, 'The Just Distribution of Harm Between Combatants and Noncombatants', Philosophy \& Public Affairs, Vol. 38, No. 4, 2010, pp. 342-379.

McMahan, Jeff, 'Duty, Obedience, Desert, and Proportionality in War: A Response', Ethics, Vol. 122, No. 1, 2011, pp. 135-167.

McMahan, Jeff, 'Proportionality in the Afghanistan War', Ethics \& International Affairs, Vol. 25, No. 2, 2011, pp. 143-154.

McMahan, Jeff, 'Summary’, Analysis, Vol. 71, No. 3, 2011, pp. 511-512.

McMahan, Jeff, 'Who is Morally Liable to be Killed in War', Analysis, Vol. 71, No. 3, 2011, pp. 544-559.

McMahan, Jeff, 'Individual Liability in War: A Response to Fabre, Leveringhaus and Tadros', Utilitas, Vol. 24, Iss. 2, 2012, pp. 278-299.

McMahan, Jeff, and McKim, Robert, 'The Just War and the Gulf War', Canadian Journal of Philosophy, Vol. 23, No. 4, 1994, pp. 501-41.

Miller, David, 'Holding Nations Responsible', Ethics, Vol. 114, No. 2, 2004, pp. 240268.

Nagel, Thomas, Mortal Questions (Cambridge University Press, 1979).

Narveson, Jan, 'Collective Rights?', Canadian Journal of Law and Jurisprudence, Vol. IV, No. 2, 1991, pp. 329-345.

Narveson, Jan, 'Collective Responsibility', The Journal of Ethics, Vol. 6, Iss. 2, 2002, pp. 179-198.

Nozick, Robert, Anarchy, State, and Utopia (Basic Books, 1974). 
Orend, Brian, "War", The Stanford Encyclopedia of Philosophy (Fall 2008 Edition), Edward N. Zalta (ed.), URL: http://plato.stanford.edu/archives/fall2008/entries/war/ (Accessed March 1, 2014).

Otsuka, Michael, 'Killing the Innocent in Self-Defense', Philosophy \& Public Affairs, Vol. 23, No. 1, 1994, pp. 79-94.

Otsuka, Michael, 'Licensed to Kill', Analysis, Vol. 71, No. 3, 2011, pp. 523-532.

Parrish, John M., 'Collective responsibility and the state', International Theory, Vol. 1., Iss. 1, 2009, pp. 119-154.

Pattison, James, 'When is it Right to Fight? Just War Theory and the Individual-Centric Approach', Ethical Theory and Moral Practice, Vol. 16, Iss. 1, 2013, pp. 35-54.

Quong, Jonathan, 'Killing in Self-Defense', Ethics, Vol. 119, No. 3, 2009, pp. 507-537.

Raikka, Juha, 'On disassociating oneself from collecting responsibility', Social Theory and Practice, Vol. 23, No. 1, 1997, pp. 93-108.

Rawls, John, A Theory of Justice (Cambridge: Harvard University Press, 1971, Rev. Ed. 1999).

Reichberg, Gregory M., 'Just War and Regular War: Competing Paradigms', in Rodin, David, and Shue, Henry (eds), Just and Unjust Warriors: The Moral and Legal Status of Soldiers (Oxford: Oxford University Press, 2008), pp. 193-213.

Roberts, Adam, 'The Principle of Equal Application of the Laws of War', in Rodin, David, and Shue, Henry (eds), Just and Unjust Warriors: The Moral and Legal Status of Soldiers (Oxford: Oxford University Press, 2008), pp. 226-254.

Rodin, David, War and Self-Defense (New York: Oxford University Press, 2002). 
Rodin, David, 'War and Self-Defense', Ethics \& International Affairs, Vol. 18, No. 1, 2004, pp. 63-68.

Rodin, David, 'The Moral Inequality of Soldiers: Why jus in bello Asymmetry is Half Right', in Rodin, David, and Shue, Henry (eds), Just and Unjust Warriors: The Moral and Legal Status of Soldiers (Oxford: Oxford University Press, 2008), pp. 44-68.

Rodin, David, 'Justifying Harm', Ethics, Vol. 122, No. 1, 2011, pp. 74-110.

Rodin, David, and Shue, Henry, 'Introduction', in Rodin, David, and Shue, Henry (eds), Just and Unjust Warriors: The Moral and Legal Status of Soldiers (Oxford: Oxford University Press, 2008), pp. 1-18.

Ryan, Cheyney, 'Moral Equality, Victimhood, and the Sovereignty Symmetry Problem', in

Rodin, David, and Shue, Henry (eds), Just and Unjust Warriors: The Moral and Legal Status of Soldiers (Oxford: Oxford University Press, 2008), pp. 131-152.

Ryan, Cheyney, 'Democratic Duty and the Moral Dilemmas of Soldiers', Ethics, Vol. 122, No. 1, 2011, pp. 10-42.

Sempa, Francis P., ‘American Exceptionalism', American Diplomacy, Oct. 19, 2011.

Shakesepeare, William, Henry V, Gurr, Andrew (ed.), (New York: Cambridge University Press, 1992, Updated Edition 2005)

Shue, Henry, 'Do We Need a 'Morality of War'?', in Rodin, David, and Shue, Henry (eds), Just and Unjust Warriors: The Moral and Legal Status of Soldiers (Oxford: Oxford University Press, 2008), pp. 87-111.

Smilansky, Saul, 'Terrorism, Justification, and Illusion', Ethics, Vol. 114, No. 4, 2004, pp. 790-805. 
Smiley, Marion, 'From Moral Agency to Collective Wrongs: Re-thinking Collective Moral Responsibility', Journal of Law and Policy, Vol. 19, Iss. 1, 2010, pp. 171-202.

Statman, Daniel, 'On the Success Condition for Legitimate-Defense', Ethics, Vol. 118, No.4, 2008, pp. 659-686.

Steinhoff, Uwe, 'Why 'We' Are Not Harming the Global Poor: A Critique of Pogge's Leap from State to Individual Responsibility', Public Reason, Vol. 4, No. 1-2, 2012, pp. 119-138.

Stilz, Anna, 'Collective Responsibility and the State', The Journal of Political Philosophy, Vol. 19, No. 2, 2011, pp. 190-208.

Strawser, Bradley Jay, 'Walking the Tightrope of Just War', Analysis, Vol. 71, No. 3, 2011, pp. 533-544.

Tadros, Victor, 'Duty and Liability', Utilitas, Vol. 24, Iss. 2, 2012, pp. 259-277.

Thomson, Judith Jarvis, 'Self-Defense', Philosophy \& Public Affairs, Vol. 20, No. 4, 1991, pp. 283-310.

Uniacke, Suzanne, Permissible Killing: The self-defence justification of homicide (Cambridge: Cambridge University Press, 1994).

US Catholic Bishops, 'The Challenge of Peace: God's Promise and Our Response', in Elshtain, Jean Bethke (ed.), Just War Theory (Oxford: Basil Blackwell Ltd, 1992), pp. 77-168.

Walzer, Michael, 'World War II: Why Was This War Different?', in Cohen, Marshall, Nagel, Thomas, and Scanlon, Thomas (eds), War and Moral Responsibility (Princeton: Princeton University Press, 1974), pp. 85-103.

Walzer, Michael, Just and Unjust Wars: A Moral Argument with Historical Illustrations (Fourth Edition), (Basic Books: 2006). 
Wilson, James Q., 'American Exceptionalism', The American Spectator, Vol. 39, Iss. , 2006, pp. 36-43.

Zimmerman, Michael J., 'Intervening Agents and Moral Responsibility', The Philosophical Quarterly, Vol. 35, No. 141, 1985, pp. 347-358.

Zohar, Noam J., 'Collective War and Individualistic Ethics: Against the Conscription of 'Self-Defense', Political Theory, Vol. 21, No. 4, 1993, pp. 606-622.

Zohar, Noam J., 'Innocence and Complex Threats: Upholding the War Ethic and Condemnation of Terrorism', Ethics, Vol. 114, No. 4, 2004, pp. 734-751.

Zohar, Noam J., 'Double Effect and Double Intention: A Collectivist Perspective', Israeli Law Review, Vol. 40, No. 3, 2007, pp. 730-742.

Zupan, Dan, 'A Presumption of the Moral Equality of Combatants: A Citizen-Soldier's Perspective', in Rodin, David, and Shue, Henry (eds), Just and Unjust Warriors: The Moral and Legal Status of Soldiers (Oxford: Oxford University Press, 2008), pp. 214225. 